\title{
INEL--94/02 28
}

IDAHO NATIONAL ENGINEERING LABORATORY, TEST AREA NORTH, HANGAR 629 SCOVILLE VICINITY BUTTE COUNTY IDAHO
HAER NO. ID-32-A INEL $-94 / 0228$

\section{RECEIVED \\ SEP 15 i998 \\ OSTI}

PHOTOGRAPHS

WRITTEN HISTORICAL AND DESCRIPTIVE DATA

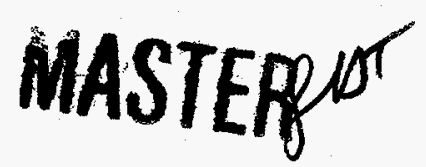

\section{DETREUTION OF THIS DOCUMET IS UAMTTED}

\author{
Historical American Engineering Record \\ National Park Service \\ Western Region \\ Department of Interior \\ San Francisco, California 94102
}




\section{DISCLAIMER}

This report was prepared as an account of work sponsored by an agency of the United States Government. Neither the United States Government nor any agency thereof, nor any of their employees, makes any warranty, express or implied, or assumes any legal liability or responsibility for the accuracy, completeness, or usefulness of any information, apparatus, product, or process disclosed, or represents that its use would not infringe privately owned rights. Reference herein to any specific commercial product, process, or service by trade name, trademark, manufacturer, or otherwise does not necessarily constitute or imply its endorsement, recommendation, or favoring by the United States Government or any agency thereof. The views and opinions of authors expressed herein do not necessarily state or reflect those of the United States Government or any agency thereof. 


\section{DISCLAIMER}

Portions of this document may be illegible in electronic image products. Images are produced from the best available original document. 


\section{HISTORIC AMERICAN ENGINEERING RECORD \\ INDEX TO PHOTOGRAPHS}



ID-32-A-5 SOUTH END OF TAN 629 HANGAR, FACING NORTHEAST. SMC BUILDING ABUTS DOORS. (AFTERNOON LIGHT).

ID-32-A-6 SOUTH END OF TAN 629 HANGAR, FACING NORTHEAST. DETAIL OF HANGAR DOOR, EMPENNAGE DOOR, DOOR

(Continued) PATCHES. 
Idaho National Engineering Laboratory, Test Area North, Hangar 629

HAER No. ID-32-A

Index to Photographs

(Page 2)

\begin{abstract}
ID $-32-A-7$
EAST SIDE OF TAN 629 HANGAR, FACING NORTHWEST. TAREN FROM BERM EAST OF HANGAR. SHOWS ROOF DETAIL.

$I D-32-A-8$

EAST SIDE OF TAN 629 HANGAR, FACING SOUTHWEST. TAKEN FROM BERM EAST SIDE OF HANGAR. DETAIL OF BARREL VAULT, ARCH RIBS, CONSTRUCTION AND EXPANSION JOINTS, RUBBER MEMBRANE.
\end{abstract}

$I D-32-A-9$

$I D-32-A-10$

ID $-32-\mathrm{A}-11$

ID $-32-\mathrm{A}-12$

ID $-32-A-13$

ID $-32-A-14$

ID $-32-A-15$

ID $-32-A-16$

ID $-32-\mathrm{A}-17$

(Continued)
WEST SIDE OF HANGAR, FACING NORTHEAST. TAREN EROM LOW ROOF OF TAN 679 ON WEST SIDE OF HANGAR. DETAIL OF ARCH ABUTMENTS, FOUNDATIONS, SMC WASTE HANDLING STRUCTURE.

WEST SIDE OF HANGAR, FACING SOUTHEAST. TAREN FROM LOW ROOE OF TAN 679 ON WEST SIDE OF HANGAR. DETAIL OF BARREL VAULT RIBS AND SIDE POCKET OF HANGAR DOOR .

INTERIOR OF TAN 629 HANGAR, TAKEN ON EAST CATWALR, EACING SOUTHEAST. DETAIL OF ROOF AND UTILITY CONDUIT, AND LIGHTS.

INTERIOR OF TAN 629 HANGAR, TAKEN FROM EAST CATWALR, FACING WEST. DETAIL OF SMC DUCTWORR PIERCING HANGAR DOOR AND BRACES SUPPORTING METAL WALL ABOVE HANGAR DOOR.

INTERIOR OF TAN 629 HANGAR, TAKEN ON LOW ROOF ON WEST SIDE, FACING SOUTH. SHOWS SMC ROOF UTILITY PAD.

INTERIOR OF TAN 629 HANGAR, TAREN ON LOW ROOF ON WEST SIDE, FACING EAST. DETAIL OF INTERIOR OF HANGAR DOORS, SMC DUCTWORR, AND TRIANGULAR BRACES SUPPORTING WALL ABOVE DOORS.

INTERIOR OF TAN 629 HANGAR, TAKEN FROM HIGH ROOF ON NORTHWEST SIDE, FACING NORTH. SMC IN FOREGROUND.

INTERIOR OF TAN 629 HANGAR, TAKEN FROM HIGH ROOF ON NORTH SIDE, FACING SOUTH. DETAIL OF EMPENNAGE DOOR DESIGNED FOR ENTRY OF AIRCRAFT TAIL ASSEMBLY.

INTERIOR OF TAN 629 HANGAR, TAREN FROM HIGH ROOF ON NORTH SIDE, FACING SOUTH. DETAIL OF INTERIOR CORNER, SHOWING JOINT BETWEEN BARREL VAULT AND SIDE WALLS, ENTRY TO DOOR POCKET. 
Idaho National Engineering Laboratory, Test Area North, Hangar 629

HAER No. ID-32-A

Index to Photographs

(Page 3)

ID $-32-A-18$

INTERIOR OF TAN 629 HANGAR, TAKEN ON LOW ROOF ON WEST SIDE, FACING NORTH. SMC DUCTWORK LEADS TO HANGAR DOOR.

ID $-32-A-19$

INTERIOR OF TAN 629 HANGAR, TAREN ON LOW ROOF ON WEST SIDE, FACING EAST. DETAIL OF HANGAR DOOR LEAVES.

ID $-32-A-20$

INTERIOR OF TAN 629 HANGAR, TAREN ON HIGH ROOF ON SOUTH SIDE, FACING SOUTH. DETAIL OF EMPENNAGE DOOR AND BRACING FOR DOOR AND HALL.

$I D-32-A-21$

INTERIOR OF TAN 629 HANGAR, TAREN FROM CRANE PLATFORM, FACING NORTHEAST. DETAIL OF CORNER.

ID $-32-A-22$

INTERIOR OF TAN 629 HANGAR, TAKBN FROM LOW ROOF, FACING NORTHEAST.

ID $-32-A-23$

INTERIOR OF TAN 629 HANGAR, TAREN FROM LOW ROOF, FACING NORTHEAST. SHOWS GROUND LEVEL USE OF FLOOR SPACE FOR TEMPORARY STORAGE OE CRATES. MOISTURE ON SUREACE IS FROM LEARY HANGAR ROOF.

Photos 24-32 are photocopies of historic photographs (or artist's rendering, in the case of ID-32-A-24). Name of the photographer is not known. These were construction progress photographs. INEL photo identification number is included.

ID-32-A-24 [ FET 57-4343] PHOTOCOPY OF ARTIST'S RENDERING OF HANGAR, WITH CUTAWAY SHOWING SOME INTERIOR FEATURES. PRODUCED IN 1957.

ID-32-A-25 [ FET 58-857] AERIAL VIEW OF CONSTRUCTION SHOWING TAN 629 HANGAR, LOORING NORTHWEST. PHOTO DATE: FEBRUARY 20, 1958.

ID-32-A-26 [ FET 58-2469] AERIAL VIEW SHOWING TAN 629 HANGAR AS ARCH RIBS EMERGE, LOORING NORTHWEST. PHOTO DATE: MAY 22, 1958 .

$I D-32-A-27$

[ FET 59-862 ] VIEW OF INTERIOR OF TAN 629 HANGAR LOOKING TOWARDS NORTHEAST CORNER SHOWING INTERIOR FACE OF SLIDING DOORS DURING CONSTRUCTION. SHROUDS COVER COUPLING STATION. PHOTO DATE: FEBRUARY 20, 1959 .

(Continued) 
Idaho National Engineering Laboratory, Test Area North, Hangar 629 HAER No. ID-32-A

Index to Photographs

(Page 4)

\begin{abstract}
ID-32-A-28
[ FET 59-5593] AERIAL VIEW LOORING EAST SHOWING OVERALL VIEW OF TAN 629 HANGAR, 100 PER CENT

COMPLETE. PHOTO DATE: OCTOBER 28, 1959.

ID $-32-A-29$

[ FET 60-1312] VIEW OF TELEVISION DOLLY IN TAN 629 HANGAR, AN ASPECT OF INSTRUMBNTATION. PHOTO DATE: MARCH 23, 1960.

ID $-32-\mathrm{A}-30$

[ FET 59-3261 ] VIEW OF INTERIOR OF TAN 629 HANGAR SHOWING COUPLING STATION AND FLOOR JUST AFTER PAINTING WITH DEVRAN 500 PAINT. PHOTO DATE: JUNE 23,1959 .

ID-32-A-31 [ FET 58-5870] VIEW OF INTERIOR OF TAN 629 HANGAR SHOWING PART OF SHADOW SHIELD AT RIGHT OF PHOTO, LOOKING EAST. PHOTO DATE: NOVEMBER 24, 1958.

ID-32-A-32 [ FET 59-1811] VIEW OF INTERIOR OF TAN 629 HANGAR SHOWING CLOSE-UP OF COUPLING STATION WITH LADDER ACCESS TO LOWER TUNNEL. PHOTO DATE: APRIL 6, 1959.
\end{abstract}

Photos 33-41 are photographic copies of architectural drawings.

ID $-32-A-33$

AS BUILT DRAWING OF TAN 629 HANGAR SHOWING GENERAL SITE PLAN AND RELATIONSHIP BETWEEN FLIGHT BNGINE TEST AREA TO ADMINISTRATION AND MAINTENANCE AREA, RAILROAD TRACKS AT SCALE OF 1 INCH TO 400 FEET. RALPH M. PARSONS DRAWING NUMBER: 1229-2 ANP/GE 5101. DATED MARCH 15, 1957.

ID-32-A-34 AS BUILT DRAWING OF TAN 629 HANGAR SHOWING NORTH AND SOUTH ELEVATIONS. RALPH M. PARSONS DRAWING NUMBER: 1229-2 ANP/GE 5-629-A-3. DATED MARCH 15, 1957 .

ID $-32-A-35$

AS BUILT DRAWING OF TAN 629 HANGAR SHOWING EAST AND WEST ELEVATIONS AND OTHER DETAILS. RALPH M. PARSONS DRAWING NUMBER: 1229-2 ANP/GE 5-629-A-4. DATED MARCH 15, 1957.

ID-32-A-36 AS BUILT DRAWING OF TAN 629 HANGAR SHOWING FLOOR PLAN AND VICINITY PLAN RELATIONSHIP TO ADMINISTRATION AND MAINTENANCE AREA. RALPH $M$. PARSONS DRAWING NUMBER: 1229-2 ANP/GE 5-629-A-2. DATED MARCH 15, 1957. 
Idaho National Engineering Laboratory, Test Area North, Hangar 629

HAER No. ID-32-A

Index to Photographs

(Page 5)

ID-32-A-37 DRAWING OF TAN 629 HANGAR SHOWING SECTION LINES

FOR DETAILS TO FOLLOW ON SUBSEQUENT DRAWINGS.

SECTIONS SHOWN FOR NORTH-SOUTH AND EAST-WEST

VIEWS. RALPH M. PARSONS DRAWING NUMBER: 1229-2

ANP/GE 5-629-A-5. DATED MARCH 15, 1957.

ID-32-A-38 DRAWING OF TAN 629 HANGAR SHOWING ROOF PLAN AND SECTIONS. RALPH M. PARSONS DRAWING NUMBER: 1229-2 ANP/GE 5-629-A-9. DATED MARCH 15, 1957.

ID-32-A-39 DRAWING OF TAN 629 HANGAR SHOWING SELECTED DETAILS OF ROOFING EDGE AND METAL WALL PANELS. RALPH $M$. PARSONS DRAWING NUMBER: 1229-2 ANP/GE 5-629-A-11. DATED MARCH $15,1957$.

ID-32-A-40 DRAWING OF TAN 629 HANGAR SHOWING COUPLING STATION ELEVATIONS, SECTIONS, AND DETAILS. RALPH $M$.

PARSONS DRAWING NUMBER: 1229-2 ANP/GE 5-629-A-15.

DATED MARCH 15, 1957.

ID $-32-A-41$

INDEX OF ALL TAN 629 HANGAR DRAWINGS IN THE RALPH M. PARSONS SERIES OF DRAWINGS OF THE FLIGHT ENGINE TEST FACILITY. RALPH M. PARSONS DRAWING NUMBER: 1229-2 ANP/GE-5-100. DATED MARCH 15, 1957.

Notes:

1. The historical photographs in this report are part of a large collection located at the Idaho National Engineering Laboratory's Photograph Library in Idaho Falls, Idaho. Negative numbers are indexed according to name of facility, year of photograph, and sequence number. Most photographs are dated.

2. The architectural drawings reproduced for this report are part of a large collection of architectural and engineering drawings located in the Records storage Warehouse at the Central Facilities Area of the Idaho National Engineering Laboratory. Each drawing is also microfilmed and indexed on INEL's Engineering Drawing Microfilm system.

3. For additional written historical and descriptive information, please see the main entry for Idaho National Engineering Laboratory, Test Area North, Hangar 629, HAER No. ID-32-A. 


\title{
HISTORICAL AMERICAN ENGINEERING RBCORD
}

\section{IDAHO NATIONAL ENGINEERING LABORATORY, TBST AREA NORTH, HANGAR 629 HAER NO. ID-32-A}

\begin{abstract}
Location: Within the Idaho National Engineering Laboratory, approximately 45 miles northwest of Idaho Falls, Idaho, Butte County, the NE $1 / 4$ of SW $1 / 4$ of $S w 1 / 4$ of Section 11. Township 6 North, Range 31 east, Boise Meridian.
\end{abstract}

Date of Construction: 1957-1959

Designer/Architect: Ralph M. Parsons Company, Los Angeles

Builder: Howard S. Wright Construction Company, Seattle, WA, with S. Birch and Sons Construction, Great Falls, MT, and D.L. Cheney Company, Seattle, WA

Present Owner: United States Department of Energy

Present Use: Specific Manufacturing Capabilities Project

(Classified manufacturing project of U.S. Army)

Significance: TAN 629 was built as the Flight Engine Test (EET) facility for the Aircraft Nuclear Propulsion (ANP) Project of the U.S. Air Force and the Atomic Energy Commission. Intended to house a test jet airplane using nuclear energy as a power source, the building was designed as a hangar with special features to accommodate engine tests, related research, training, and hazards associated with the experiments.

Although a ground experiment in 1956 proved the principle that a nuclear reactor could power a jet engine, many problems in engineering and designing a nuclear-powered aircraft remained to be tested and solved. President John F. Rennedy canceled the project in March 1961 because the promise of solving these problems appeared remote and because other national defense programs, particularly long-range missiles, offered more immediate and practical benefits.

The hangar, which was never beneficially occupied by the ANP program, was then adapted for other experiments and uses at the (then-named) National Reactor Testing station. It is a reminder of the optimistic and urgent Cold War hopes that the military establishment placed in the power of the atom to fuel a bomber with unlimited world-wide range.

Report prepared by: Susan M. Stacy 1718 North 17 th Street Boise, Idaho 83702

Date: August 12,1995 
INEL, TAN, HANGAR 629 HAER NO. ID-32-A

Page 2

TABLE OF CONTENTS

Part 1 Background/Description of the Hangar Site ... Page 4 Part 2 The Idea of the Atomic Airplane .......... Page 9

Part 3 The NEPA Years .................. Fage 13

Part 4 General Electric and the ANP Direct Cycle ... Page 19

Part 5 Test Area North and the Initial Tests ...... Page 22

Part 6 Redirection: Don!t Fly! Fly Early! ........ Page 24

Part 7 Designing the FET: TAN 629 Hangar ........ Page 31

Part 8 The ANP Experiments ................ Page 43

Part 9 Termination of the ANP Program .......... Page 48

Part 10 After ANP: One Hangar For Rent .......... Page 56

Part 11 The Hangar Today: Project $x \ldots \ldots \ldots$ Page 62

Part 12 Notes on Historic Context ............. Page 69

Appendix A: Photo Rey Map ............. Page 81

Appendix B: Vicinity Map for TAN Area ...... Page 82

Appendix C: Plot Plan for ANP Complex ...... Page 83

Bibliography .................... Page 88 
INBL, TAN, HANGAR 629

HABR NO. ID-32-A

Page 3

\section{PHOTOGRAPHS AND FIGURES}

1. INEL general site map .................. Page 8

2. Aircraft mission profile ................. Page 11

3. View of Initial Engine Test facility. ......... Page 25

4. Cutaway view of TAN 629 Hangar .............. Page 30

5. Layout of Hangar and Control buildings ......... Page 34

6. Layout within Hangar ................. Page 37

7. Aerial view of Hangar in $1958 \ldots \ldots \ldots \ldots$ Page 40

8. Aerial view of Hangar in $1959 \ldots \ldots \ldots \ldots$.................. 42

9. HTRE Reactor during construction ............ Page 45

10. HTRE assembly ...................... Page 47

11. HTRE-3 assembly ...................... Page 49

12. Aerial view of Hangar in $1989 \ldots \ldots \ldots \ldots \ldots$ Page 64

13. Map of ANPP facilities in United States ........ Page 71

14. Artist's sketch of crew compartment ......... Page 77

15. Simulator facility at wright Field .......... Page 77

16. Menu for a 120 day flight .............. Page 79 
INEL, TAN, HANGAR 629

HAER NO. ID-32-A

Page 4

PART ONE

\section{BACRGROUND AND DESCRIPTION OE THE HANGAR SITE}

In 1948 the Safeguards Committee of the Atomic Energy Commission (AEC) considered the problem of where in the nation to locate a proposed experimental 30,000-watt nuclear reactor. The AEC wanted to test the behavior of metals and coolants under prolonged exposure to radiation. The committee was determined that the reactor not be near Chicago, the location of the AEC's Argonne National Laboratory, because an accident there could potentially expose four miliion people to nuclear radiation. "We didn't want to put work like this next to a high school," said AEC Commissioner sumner Pike several years later. 1

Up to this time, the AEC had selected its reactor sites one by one for the war-time purpose of producing atomic bombs. Now that the war had ended, the AEC was setting a course for a substantial program to develop and test other nuclear power applications. The safeguards committee recommended a new approach, one that would take into account chemical processing and the disposal of radioactive waste. Using the language of military ordnance testing, it suggested that ABC create a "proving ground" where all dangerous experiments could be conducted. 2

Thus began the search for a site meeting certain safety criteria. There should be fewer than 10,000 people in the surrounding area, and that region should contain no other installations vital to the national defense. The AEC must have

1 quoted by Revin Richert in "Original AEC Site spawned Eastern Idaho's 'Gold Rush," (Idaho Falls) Post Register, May 15,1994 , p. $\mathrm{H}-20$.

2 Richard G. Hewlett and Francis Duncan, Atomic Shield, 1947-1952, Volume II of a History of the United states Atomic Energy Commission (Pennsylvania State University Press, 1969), p. 185-188. 
INEL, TAN, HANGAR 629

HAER NO. ID-32-A

Page 5

complete control of the property. ${ }^{3}$ Further, the site must have access to fuel, plentiful water, and electrical power; and suitable weather, geological, and topographical conditions to prevent contamination of lakes and waterways. Earthquake-prone sites were out. ${ }^{4}$

The search settled on two final candidate sites-Fort Peck, Montana, and the Naval Proving Ground in Southeast Idaho. Proponents for each argued energetically for their choices. The AEC hired a Detroit engineering firm to compare the two sites, and it recommended Idaho. In February 1949, the ABC accepted the recommendation and began negotiating for the 270-square mile site with its owner, the United States Navy. 5 In May the AEC hired a contractor to drill a test well for fresh water. 5 The site passed this test easily, and National Reactor Testing station (NRTS) began to grow at once. The AEC located its Idaho Operations office at Idaho Falls. Area residents soon adopted the habit of referring to the Testing station as "the site," a name that continued in use even after the Department of Energy changed the name to Idaho National Engineering Laboratory in 1974. This report will do likewise.

The eastern boundary of the site was located about 25 miles west of Idaho Falls; the southeastern, about 40 miles north of Pocatello. During World War II, the Navy had used the property in conjunction with the Naval ordnance Depot in Pocatello, where it relined large-bore guns for Navy battleships. The Navy used part of the proving grounds to test-fire the relined guns, while the Army Air Corps used part of it for an aerial gunnery range. 7

The "proving ground" for nuclear reactor experiments lies on the northern edge of the Eastern Snake River Plain at an average elevation of 4,865 feet. This broad windswept plain is extremely dry and fairly flat. It is covered with a thin blanket of soil

${ }^{3}$ Hewlett, p. 196.

4 Hewlett, p. 206.

5 Because of expansions since 1949, the site in 1994 consists of 892 square miles.

6 Hewlett, p. 210.

7 Atomic Energy Commission, Idaho Operations office, National Reactor Testing station, Thumbnail Sketch July $1962, p$. 6. Thumbnail Sketch was published approximately annually for public distribution and revised with each issuance. Hereafter cited as Thumbnail sketch with pertinant year of issue. 
INEL, TAN, HANGAR 629

HAER NO. ID-32-A

Page 6

that supports a desert sagebrush plant and animal community. To the west and north of the site are Basin and Range mountains known as the Lost River Range, the Lemhi Range, and the Bitterroot Range. Although these mountains drain their abundant winter snows into valley streams that flow towards the reactor test site, the streams disappear, their waters percolating through porous soils to an underground aquifer.

The Eastern Snake River Plain extends south beyond the boundary of the site until it reaches the snake River. The view south contains the imposing profiles of Big southern Butte, Middle Butte, and East Butte, three remnants of volcanic events that occurred 500,000 years ago. ${ }^{8}$ Each butte rises dramatically and abruptly from the plain surrounding it. East of the site the towns of Rexburg and Idaho Falls are situated on the banks of the Snake River, which rises in the Teton Mountains still further east and then flows in a southwesterly arc across southern Idaho.

Beneath the sagebrush desert, which receives less than ten inches of precipitation a year, the snake River Plain Aquifer consists of alternating layers of basalt lava flows, volcanic ash, and sedimentary deposits of sand, gravel, and clay. The uneven distribution of these flows and deposits provides some variety in surface relief, so that the terrain includes small knobs, basins, and ravines--and a few larger volcanic buttes. The total thickness of the basalt and sediment layers ranges between 2,000 and 10,000 feet. Water moves easily and swiftly among the basalt fractures, lava tubes, and pervious layers of gravel. The aquifer discharges over eight million acre-feet of water every year. It lies in wait under most of the site, available merely by piercing the earth and pumping it to the surface wherever it is needed.

The lava rock underlying the surface, aside from containing its generous reservoir of water, also provided a variety of strong footing and foundation conditions for the type of construction anticipated at the site. Depth to rock from the surface varies, offering engineers a choice of conditions for everything from roadways, railways, and fuel tanks, to

8 Bill Hackett, Jack Pelton, and Chuck Brockway, Geohydrologic story of the Eastern Snake River Plain and the Idaho National Engineering Laboratory (Idaho Falls: U.S. Dept. of Energy Idaho Operations Office, Idaho National Engineering Laboratory, 19681, p. 11-14.

9 Hackett, p. 7-9. 
INEL, TAN, HANGAR 629

HAER NO. ID-32-A

Page 7

foundations for dense concrete piers. 10

A view from an airplane in 1994 would show that across the Site lie several clusters of buildings dotted here and there at considerable distances from one another, each surrounded by sagebrush expanses. Ribbons of highway and railroad track connect the clusters. At a closer range, the clusters are likely to show the outlines of tall emission stacks, large and small rectangular buildings, storage tanks, and a miscellany of warehouses, equipment yards, guard houses, and power transmission lines. Surrounding each cluster, chain link fences topped with barbed wire and night lights provide a barrier against both human intruders and animals such as antelope and deer.

One of the clusters in the south central part of the site is the Central Facilities Area (CFA). This was where the Navy had placed its administrative offices, warehouses, and several residences when it operated the proving ground. The AEC adapted these buildings and built others to serve as a hub of supply, security, administration, and other support activities for the reactor experiments that began after 1949. At suitably safe distances from one another, other clusters radiate loosely around the CFA, ranging from two to twenty-five miles away. Contractors and employees identify these clusters with alphabetical acronyms describing the experiment: EBR-1, Experimental Breeder Reactor; SPERT, Special Power Excursion Reactor Test; ZPPR, Zero Power Physics Reactor; ARA, Army Reactor Area; and many others.

In the far northern reach of the site is a complex cluster, thirty miles from the Central Facilities Area and obviously more isolated than the rest. This is Test Area North (TAN). The AEC designated this area for tests that the United States Air Force hoped would result in the flight of a nuclear-powered turbojet airplane. The Air Force envisioned a bomber that would have unlimited range around the world, that could stay aloft for up to seven days at a time, that could sprint fast enough to evade any enemy ajrcraft, and that could deliver its payload anywhere on earth. 11

Test Area North is about ten miles from the eastern site

10 "Thumbnail sketch," July 1962, p. 3.

11 John E. Pickering in "Radiobiological Aspects of Aircraft Nuclear Propulsion," in Kenneth F. Gantz, Nuclear Elight (New York: Duell, Sloan, and Pearce, 1960), p. 167. Seven days was considered the limit to extreme physical confinement, isolation, high noise level, four-hour rotation of work and rest, limited facilities for personal hygiene, and other factors. 


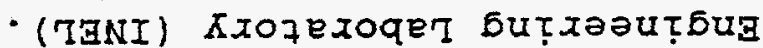

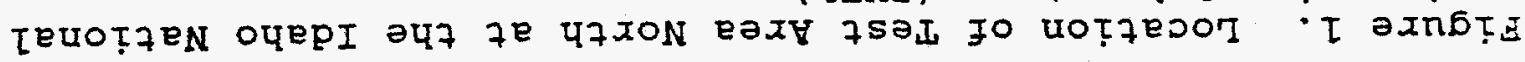

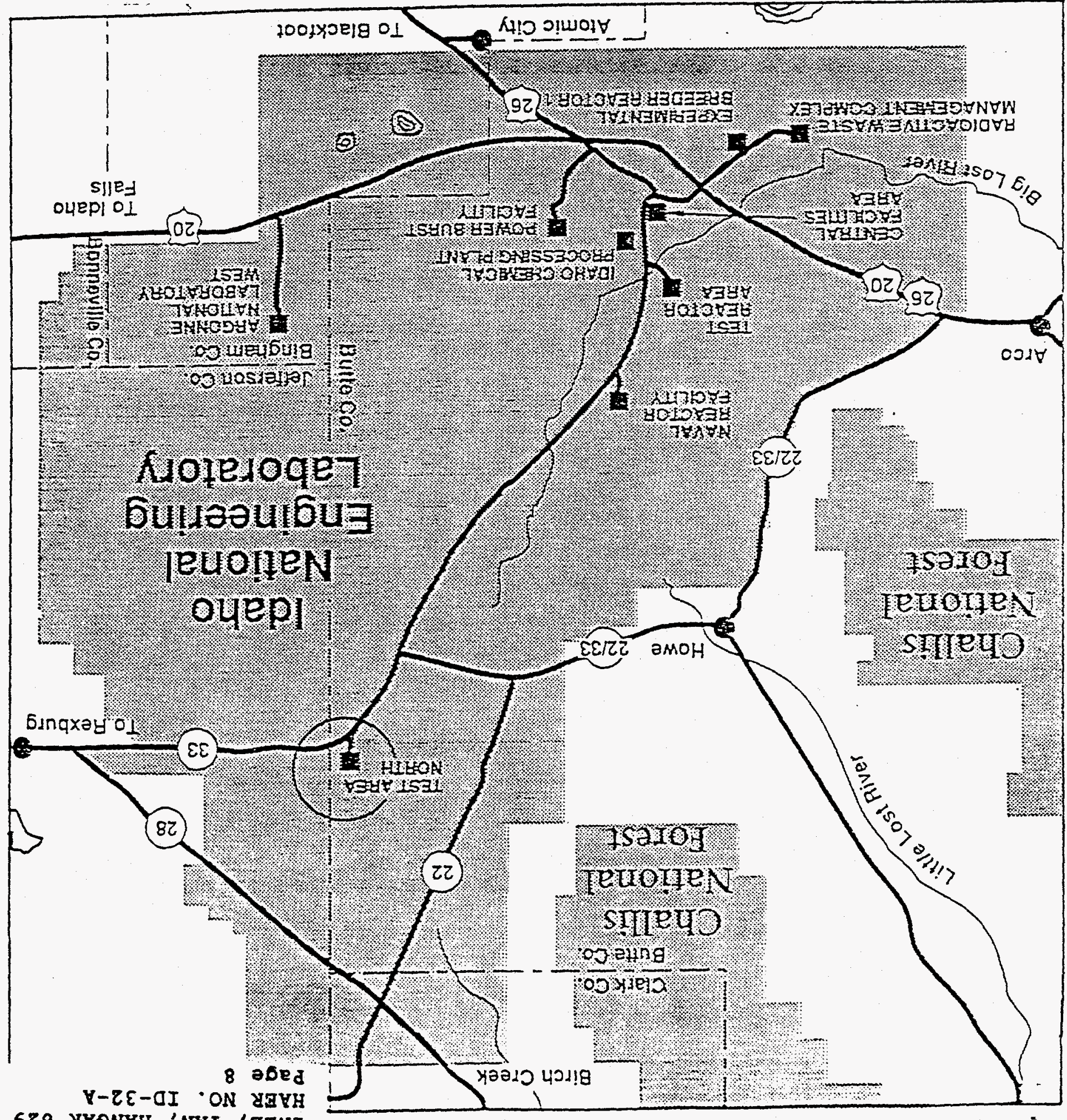


INEL, TAN, HANGAR 629

HAER NO. ID-32-A

Page 9

boundary. The tiny settlements of Mud Lake and Terreton lie a few miles further east. The southern hills of the Lemhi Range rise to the west. North of TAN Birch Creek sinks into the soil and disappears into the aquifer. The TAN cluster is itself composed of several groupings of buildings around a central area, each of which served its special purpose in the series of experiments intended to prove the feasibility of the atomic aircraft.

One of the buildings is a rather large airplane hangar, the round contours of its dark roof contrasting notabiy with the other structures. A survey of the area nearby discloses no airplane runway. The following chapters explain how this building came to be located at such an unlikly place.

\section{PART TWO}

\section{THE IDEA OF THE ATOMIC AIRPLANE}

The Manhattan Project created the world's first atomic explosion at Alamagordo, New Mexico, on July 16, 1944. Six months before that, Army Air Corps engineers already were imagining the possibilities of atomic power for flight. Colonel Donald $\mathrm{J}$. Reirn, an Army Air Corps specialist in the field of aircraft power plants, had visited England on a secret mission in 1941 to examine Commodore Sir Frank Whittle's pioneering jet-propelled aircraft engine. After recommending that the United states build the engine, Reirn continued as the liaison between the Air Corp's Wright Field in Dayton, Ohio, (home of the Air Research and Development Command) and General Electric and Bell Aircraft Corporations, the contractors developing the country's first jet aircraft. Although these companies produced flying jets as early as 1943, the planes did not fly in combat during the war. ${ }^{2}$

The new jets promised high speed, an asset useful for the defensive activity of intercepting incoming enemy bombers, but their high fuel consumption and short range limited their offensive possibilities. If an enemy were to use jet aircraft in Thus, an American aircraft combining high speed with long range

\section{W. Henry Lambright, Shooting Down the Nuclear Airplane}

(Syracuse, N.Y.: Inter-University Case Program, 1967), p. 2; see also John Tierney, "Take the A-Plane: The Nuclear Bird that Never Flew," Science 82 (Jan-Feb, No. 1), p. 47; Grover Heiman, Jet Pioneers (New York: Duell, Sloan, and Pearce, 1963), p. 54 ff.

$$
13 \text { Hewlett, p. } 72 \text {. }
$$


INEL, TAN, HANGAR 629

HAER FO. ID-32-A

Page 10

and a cargo of bombs would be a useful weapon indeed.

Keirn and D.R. Shoults, one of the executive engineers at General Electric, considered the possjbility of linking jet engine technology with nuclear power. 14 They knew that nuclear fuel would be of negligible weight and occupy less space than a baseball. The energy in one pound of highly enriched uranium-235 could replace that contained in 1.7 miliion pounds of standard chemical fuel, effectively ending flight distance limits. ${ }^{\mathrm{A}}$ nuclear-powered airplane could deliver bombs anywere in the world from any direction without relying on refueling stations, bases in foreign lands, or any of the support systems, personnel, costs, and risks that these would require.

Keirn and shoults launched their discussion in wider circles and found that their enthusiasm was not shared equally by all of their audiences. Reirn approached Vannevar Bush, the Director of the office of Scientific Research and Development for the Manhattan Project, in 1944. Bush, whose main worry was developing an atomic bomb, suggested that Reirn forget about it. 16 Later, as the war was ending, Keirn found Major General Leslie Groves, the head of the Manhattan Engineering District, to be more encouraging.

Shoults had discussed the idea with other contractors in the military aircraft industry and found ready support. On october 11,1945 , J. Carlton Ward, Jr., president of Fairchild Engine and Airplane Corporation testified before a senate committee that the industry supported researching an atomic airplane. When a senator asked him how future atomic bombs would be delivered, he replied that "an atomic plane limited in range only by sandwiches and coffee for the crew" would do the job.17

The nuclear physicists most deeply involved in the

${ }^{14}$ Lambright, p. 2 .

15 "Potential Nuclear Power Plant," Aircraft Nuclear Propulsion Department News, Special Review Section for AHA Members, (Vol. 4, No. 18; May 6, 1960), p. 3. Copy in Idaho Historical Society, Boise, Idaho, MS. 84, (hereafter cited as Dworshak Papers), Box 112, File: Atomic Energy Commission, Miscellaneous.

${ }^{16}$ Donald J. Keirn, "The U.S. Air Force Nuclear Propulsion Programs," in Gantz, Nuclear Flight, p. 13. See also Lambright, p. 3, and Hewlett, p. 72 .

17 Tierney, p. 47; see also Lambright, p. 3 . 


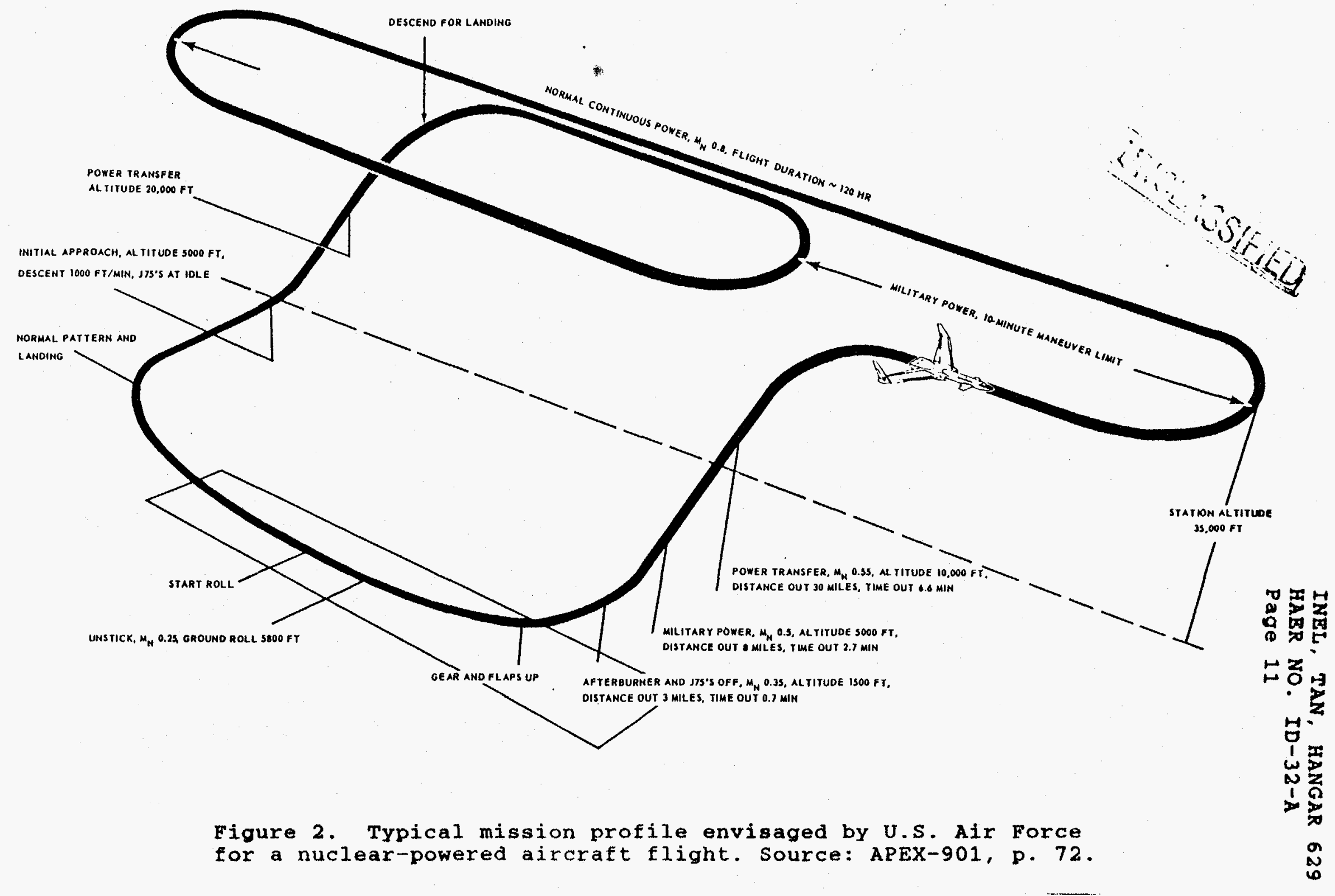


INEL, TAN, HANGAR 629

HAER NO. ID-32-A

Page 12

production of the atomic bomb, among them J. Robert Oppenheimer, seriously doubted that an atomic aircraft would be feasible.

Certainly, the state of reactor development at that time did not warrant any optimistic schedules for an airplane. Too much was simply unknown. However, the Army Air Corps and Congress proceeded despite scientific reservations.18

Four aircraft manufacturers proposed that the Air Force (an independent military service created from the Army Air corps by the Defense Reorganization Act of 1946) funded a feasibility study for aircraft nuclear propulsion. In May 1946 the Air Force granted Fairchild Engine and Airplane Corporation the prime contract, naming the program Nuclear Energy for the Propulsion of Aircraft: NEPA. ${ }^{19}$ The AEC cooperated by allowing the project to conduct research at its existing facilities at Oak Ridge, Tennessee. The Army would provide the NEPA group housing and laboratory space.

The Fairchild engineers originally thought of the project as a fairly simple two-part process. They would do the propulsion engineering, while nuclear physicists of the Monsanto Corporation, with whom they could collaborate, would produce a reactor design. Monsanto already was at Oak Ridge working on the development of nuclear power reactors.

Keirn was placed in charge of reviewing project contracts, maintaining security, and developing research proposals. The understanding among the aircraft contractors was that, although Fairchild would be the prime contractor, various phases of the work would be distributed eventually to nine other companies. The Air Force named a board of consultants, consisting of representatives of the nine companies and various military aeronautics committees, to receive and evaluate the anticipated reports and other results that would come from the research. 20 work commenced.

18 Tierney, p. 47.

${ }^{19}$ The Air Force did not actually select Fairchild; rather, a group of aircraft engine companies, of which Fairchild was one, selected Fairchild to manage the contract with the understanding that the others would become subcontractors.

20 Hewlett, p. 72. The Comptroller General's account (see full citation in Note 30 ) reports ten other companies, not nine. Also, see pp. 17-25 of Comptroller Report for references to Air Force and $A E C$ contract dates and numbers. 
INEL, TAN, HANGAR 629

HAER NO. ID-32-A

Page 13

PART THREE

THE NEPA YEARS

The first Air Force researchers-mostly engineers--arrived at Oak Ridge in September 1946. They found a lack of both the promised housing and office space and were forced to locate in an isolated area about 12 miles from Monsanto. The situation contributed to poor morale, memo-writing, and complaint. However, the 30 employees of the project, under the direction of Gordon Simmons, Jr., began their paper computations and studies. The object was to design a system that would transfer the heat generated by a nuclear reaction in such a way as to propel an aircraft. They would consider applications for propeller jets, turbo jets, and ramjets. The engineers knew very little about nuclear reactors and what opportunities--or difficulties--they might offer for flight. 21

This weakness in the program became apparent to the Atomic Energy Commission in March 1947 after Simmons and Fairchild's president ward briefed the ABC's subcommittee on Research and Development. In addition, committee members questioned whether the Air Force had articulated a military justification for the ultimate product of the research. Ensuing discussions with Air Force generals produced more specific descriptions of the bomber's desired performance: a range of 12,000 miles at a speed of 450 miles per hour. Conventional bombers could not carry enough fuel for such a mission. Air Force General Curtis LeMay was convinced that future wars would be fought without the benefit of advanced bases for sortie departures or refueling. An atomic plane would therefore be an essential weapon. 22

Again, AEC advisors J. Robert Oppenheimer and Harvard chemist James B. Conant, members of the AEC's General Advisory Committee, expressed grave doubts. NEPA expectations of an aircraft in five years were naive, they felt, because far too much remained unknown. The AEC was just launching a reactor research program with the ultimate purpose of developing applications for a broad range of civilian and military uses. But before private industry--or the military--could proceed, a great deal of expensive scientific inquiry was necessary first. The scientists felt that the Air Force approach, focused as it was on the rapid development of a test flight, was unsound. The project should be integrated into the general reactor development program of the AEC, not isolated separately at Oak Ridge. The Conant

$$
\begin{aligned}
& 21_{\text {Hewlett, p. } 73 .} \\
& 22_{\text {Hewlett, p. } 73 .}
\end{aligned}
$$


INEL, TAN, HANGAR 629

HAER NO. ID-32-A

Page 14

committee recommended that NEPA be terminated and that the AEC incorporate into its reactor research program the development of high-temperature reactors. Later, an aircraft company could design ann airframe (the body of the aircraft) for the Air

The basic function of a nuclear reactor in an aircraft was to generate extremely high temperatures. In a conventional system, heat is produced by the combustion of chemical fuel. Air passes through a compressor, is heated (thereby increasing its pressure), passes through a turbine, and is exhausted through a small opening at the rear of the aircraft, thus providing thrust in the opposite direction. Some energy is extracted from the turbine to run the compressor. The reactor would replace the combustion chamber. It would have to generate heat of extremely high temperatures, be small enough to operate within an airframe, be light enough to be lifted, and be constructed of materials that would perform reliably under conditions of tremendous heat, compression, and stress.

Many technical and safety barriers stood in the way. The metals, rubber, and other materials of which the engine, airframe, and reactor were constructed would have to survive prolonged exposure to various forms of radiation and the corrosive force of high temperatures rushing past at great speed. Reactors developed for the atomic bomb had promoted a nuclear reaction so rapid that it resulted in a sudden explosion of energy. Reactions intended to be slower and more controlled--as in this application--required the use of moderators like graphite, which were extremely heavy. Since the craft was to be manned, the crew needed to be shielded from radiation. State-ofthe-art shielding technology then current relied on lead plates and thick concrete barriers that surrounded the reactor in quantities far too heavy for flight. The shield in the aircraft would have to be pierced to allow the air to pass through and acquire heat. Aside from the nuclear aspect of the problem, a system for transferring heat from the reactor to the turbojet engine also needed to be developed. The air passing through the reactor would pick up fission products which, if not contained, would poison landing areas, hangars, and exhaust trails--yet another serious problem.

Creating a reactor that could produce the required heat under steady and reliable control; discovering or creating--and then testing--appropriate materials; reducing the weight of the shielding; engineering a safe heat transfer system: Oppenheimer and other scientists argued that no one really knew how long it

${ }^{23}$ Hewlett, p. 74,106 . 
INEL, TAN, HANGAR 629

HAER NO. ID-32-A

Page 15

would take to solve all these problems. Setting "fly early" target dates was not realistic.

After its discussion of the NEPA project, the AEC responded to both the technical and military issues. First, it convened an independent study group of over 40 scientists in 1948 at the Massachusetts Institute of Technology (MIT) to review NEPA's progress and answer the question of whether nuclear power could feasibly propel an aircraft. The group, known as the Lexington Project, met during the summer in an old bunker on the MIT campus and decided that the many and substantial problems could theoretically be solved. It noted also that other technologies, such as improved missiles, might make an atomic airplane obsolete by the time it was developed.

When the Lexington group published its report, proponents and opponents both found encouragement in its pages. The Air Force emphasized that the group affirmed "a strong probability that some version of nuclear-powered flight can be achieved," albeit only with a substantial and sustained expenditure of time, money, manpower, and the willingness to carry out such a complex project. It predicted that a billion dollars and fifteen years might do the job. Opponents stressed the warnings, such as, "It is to be expected that crashes may occur, and the site of a crash will be uninhabitable." The Lexington group concluded that it was up to the nation to decide if it wished to make an atomic plane a priority. 24

Second, the AEC asked its Military Liaison Committee to articulate the military justification for the project and answer whether it was worth $\$ 1$ billion and 15 years of effort. When the committee met in December 1948, the scientists once again criticized the project, but the Air Force generals felt certain that the United states must be able to do without the Iuxury of overseas bases in the next war. Without bases, they argued, "No matter how large our stockpile of atomic bombs may be, this stockpile would become the tragic Maginot Line of forlorn hope, if the bombs remained undelivered over the targets where the $y_{5}$ would damage the enemy's war-making capacity to the utmost." 25

At the end of their deliberations in December 1948, the AEC decided to continue financing NEPA's feasibility studies in Oak Ridge at a level of about $\$ 3$ million annually for the next two or

${ }^{24}$ Tierney, p. 49; also Lambright, p. 5.

25 General Turner A. Sims, quoted in Hewlett, p. 211. 
INEL, TAN, HANGAR 629

HAER NO. ID-32-A

Page 16

three years. 26

A new director of the effort, Mils $C$. Leverett, formerly the developer of reactor development at Oak Ridge, began to expand the size and improve the technical competency of the NEPA group. During the 1949-50 period the group conceived the idea of a "divided shield" in the aircraft. Instead of placing all of the shielding around the reactor, the plan was to place a shield around the crew and put as much distance between the crew and the reactor as possible. Less shielding could then be used around the reactor, reducing overall shield weight. The group began testing materials that might offer lighter weight protection. Oak Ridge, where elaborate facilities such as the shield Test Tower featured a nuclear reactor suspended outdoors in midair to emulate its position in an aircraft, became the center of shield studies for the next ten years, although NRTS and other facilities in the country also participated. 27 one series of tests even flew operating reactors (as passengers) in an airplane over New Mexico and the Gulf of Mexico to measure radiation attenuation and dispersion. Shield science evolved as a nuclear specialty. Periodically, interested researchers gathered from żcross the country to attend "shielding information meetings." 28

Other specialists focused on the characteristics of a reactor that would operate most productively in an airplane. They had to test various combinations of fuel, cladding materials, moderators, coolants, and structural materials. They considered, for example, that reactors using a liguid metal coolant might transfer more heat from the reactor to the turbojet airstream.

Meanwhile, the Joint Committee on Atomic Energy (JCAE), a Congressional committee created by the Atomic Energy Act of 1945 to oversee AEC policy and appropriations, emerged as a strong and enthusiastic constituency for the atomic airplane. Hopes for a peaceful and tension-free post-war world evaporated rapidly as a gulf of mistrust and competition opened between the United states

26 Hewlett, p. 420 .

27 The Tower Shielding Facility at Oak Ridge has been assessed as eligible for nomination to the National Register of Historic Places. See Martha Carver and Margaret Slater. Architectural/ Historical Assessment of the Oak Ridge National Laboratory, Oak Ridge Reservation, Anderson and Roane Counties, Tennessee, ORNL/M-3244 (Oak Ridge: Martin Marietta Energy Systems, Inc., 1994), p. 307.

28 See APEX-322, Semiannual ANP Shielding Information Meeting, May 1-2, 1957, Vol 1 (Cincinnati: ANP Department). 
INEL, TAN, HANGAR 629

HAER NO. ID-32-A

Page 17

and the soviet Union. The Soviets had made incursions into eastern Europe after the war; it had detonated an atomic device in 1949; the communist Chinese Red Army had taken control of China the same year: the Rorean Var began in 1950. Senator Joseph McCarthy began a hunt for communists in the government; his hearings contributed to a rising sense of alarm and paranoia within the United States. All these events reinforced the idea that the country had a fearful enemy, one that grew more potent and threatening all the time.

The Soviet detonation of a nuclear device had particularly alarmed the JCAE and the rest of the ARC community because it demonstrated that this incipient enemy possessed more advanced knowledge and capability than American intelligence estimates had predicted. JCAE member Melvin Price of Illinois and the others vowed that the United states would not lose the race for weapons superiority over the enemy. Clearly, new weapons demanded research. The JCAE and its staff executive director, Filliam L. Borden, encouraged the Department of Defense to issue a specific "requirement" for the airplane that would justify the research effort. 29 Despite the increasing urgency of the Cold War and the pressing need for more applied scientific research for national defense 30 a military statement proved to be a long time in coming. 30

By 1950 the institutions concerned with the atomic airplane had defined their basic views. The JCAE, the Air Force, and the contractors desired to "fly early," and not place the nuclear reactor for aircraft propulsion in the context of general reactor development. As the 1950 s progressed, this group gradually justified flying an aircraft that would not even meet military performance standards on the grounds that any flight at all would provide a "psychological" blow to the enemy and a boost at home. After 1957, when the Soviet Union launched a satellite (Sputnik) into orbit around the earth, the value of being first with an atomic airplane seemed even more urgent, for sputnik had struck a severe blow to American scientific prestige and confidence. Aircraft contractors mounted forceful lobbying and educational efforts that kept the distasteful prospect of soviet progress

29 Hewlett, p. 219.

${ }^{30}$ Comptroller General of the United States, Review of Manned Aircraft Nuclear Propulsion Program, Atomic Enercy Commission and Department of Defense (Washington, D.C.: Government Accounting office, February 1963), D. 123. The Comptroller General prepared this evaluation for Congress after the ANP Program was terminated. Hereafter cited as Comptroller General. 
INEL, TAN, HANGAR 629

HAER NO. ID-32-A

Page 18

ever before the JCAE.

science advisors, on the other hand, particularly those counseling the president and the Secretary of Defense, favored a "good science first, then $f l y$ " approach. Federal budget institutions also weighed in with recommendations for program reductions or cancellation. Civilian authorities at the Department of Defense, who answered to the president and who had to distribute scarce military resources, often found that other projects offered quicker benefits than a distant and doubtful nuclear bomber. They wanted real weapons that rould perform real combat service, not weak imitations of conventional bombers. 31

The retrospective opinion of analysts who have written about the ensuing struggles over the nuclear airplane is that the political pressures pushing to "fly early" eventually helped kill the program. The enthusiasm for the project was usually for the wrong reasons. Herbert York, as Director of Defense Research and Engineering, said in 1959 that the ANP program "has been characterized by attempts to find short cuts to early flight and by brute force and expensive approaches to the problem.... we are still at least four years away from achieving flight with a reactor-engine combination... which can just barely fly." $32^{a}$

Towards the end of 1950 the NEPA group at Oak Ridge, which had grown to 263 members, was drawing plans for an aircraft reactor experiment. Work was underway on metallurgy problems, heat-transfer, control systems, and shielding. The team felt ready to move from paper studies to serious experiments. still. the AEC had doubts. The Air Force was noted for making overly optimistic claims, and the $A B C$ had not yet heard the Department of Defense say that it supported a long-term program leading to this weapon. In view of the fact that the experiments would have to use fissionable material, a substance in short supply even for weapons, the AEC wanted a clear statement of military priorities. Early in 1951, the Joint Chiefs of staff weakly responded that they recognized the technical feasibility of the project. The AEC staff considered this reply as "a complete abdication of authority." The AEC staff appealed to the congressmen on the JCAE

\section{${ }^{31}$ Lambright, p. 2 .}

32 Quoted by Comptroller General, p. 33. See also York's account in Race to Oblivion (New York: Simon and Schuster, 1970), p. 63. A physicist, York ras involved in the Manhattan project and served later in several government positions related nuclear research. President Eisenhower appointed him in 1958 as the first Director, Defense Research and Engineering. Also, see discussions by Tierney, p. 47, and Lambright, p. 32 . 
INEL, TAN, HANGAR 629

HAER NO. ID-32-A

Page 19

for help. The JCAE conducted a hearing on February 16, 1951, and assured the Joint Chiefs that the project enjoyed congressional support. 33

On March 13, 1951 the Department of Defense finally decided that a "military requirement" existed for nuclear aircraft. In the priority list, the plane registered just below the need for reactors that would produce fissionable material. The ABC and the Air Force could now switch their emphasis from research to development. The AEC began executing contracts. It officially ended the NEPA project in April, all parties happy to drop its name and the negative image it held with the scientists. The ney start took on a new name--Aircraft Nuclear propulsion, or ANP. 34

PART FOUR

\section{GENERAL ELECTRIC AND THE ANP DIRECT CYCLE}

The NEPA engineers had devised two general designs for the problem of transferring reactor heat to the compressed air in the engine. In the "direct cycle" approach, the air would enter the compressor, flow through the reactor where the nuclear reactions generated heat, and absorb this heat directly from the fuel elements. It would then pass through the turbine and be expelled through the exhaust nozzle. ${ }^{35} \mathrm{BY}$ contrast, the "indirect cycle" provided an intermediate heat exchanger between the air and the reactor. A liquid metal, contained in a closed loop of piping, would flow through the reactor core to absorb heat. Acting as a radiator, this hot metal would give up its heat to air that would then flow through the engine. The liquid metal would return to the reactor to be reheated.

Each system had advantages and disadvantages. The direct method was considerably simpler, but air is a poor absorber of heat. Therefore, a larger volume of air would have to pass through the reactor in order to absorb enough energy to produce

\section{${ }^{33}$ Hewlett, p. 491 . \\ ${ }^{34}$ Lambright, p. 5 .}

35 Among the public relations documents produced by General Electric in 1959 was "Idaho Test Station, Idaho Falls, Idaho," a pamphlet describing GE's general activities concerning the ANP program. It includes explanations and diagrams explaining the direct cycle concept. Copy in Dworshak Papers, Box 112 File: AEC Idaho Plant. 
INEL, TAN, HANGAR 629

HAER NO. ID-32-A

Page 20

enough thrust in the engine to lift the plane. Thus, the overaII reactor design would not be very compact. The indirect approach could use a smaller reactor, which would reduce the size and weight of the required shielding. (Shielding requirements increase with the diameter of the reactor.) But the circulating liquid metal and the heat transfer plumbing required more precise and complex engineering.

The Air Force and AEC decided to pursue both concepts in a competitive spirit, assigning each to a different contractor. General Electric (GE) got the contract for the direct cycle and began work in 1951. ${ }^{36}$ Its Aircraft Nuclear Propulsion Program was centered in Evendale, Ohio, where it planned and designed experiments and tests. In July 1952, GE and AEC determined that the ground experiments would take place at the National Reactor Testing station in Idaho.

Elsewhere, the Pratt and Thitney Aircraft Division of United Aircraft Corporation undertook the indirect cycle. However, that company did not start in earnest until 1953 because 9 disputes with the Air Force and the AEC over contract terms. 37 In the race, therefore, GE had a head start. D.R. Shoults was in charge. The Air Force and the AEC created a Joint office of ANP to coordinate the program among the two agencies and the two main contractors. Donald Keirn, now a Major General, was director. 38

The program goals at this point were to develop information on reactor materials, shielding, the power plant, and the airframe design. ${ }^{39}$ th the end of three to five years, the Air Force and the ABC would evaluate feasibility again-perhaps proceed to flight tests, perhaps not. The scientists felt that much useful research could be accomplished during this time,

${ }^{36}$ Air Force Contract No. AF $33(038)-21102$ (to develop. manufacture and ground test a nuclear power plant suitable for testing at the earliest feasible date), and AEC Contract No. AT(11-1)-171 (develop a nuclear reactor which, with the propulsion equipment, would fulfill Air Force requirements).

37 Lambright, p. 6 .

${ }^{38}$ For a more detailed description of the management structure created to coordinate and oversee ANP, see Reirn in Gantz, cited in Note 15.

${ }^{39} \mathrm{~A}$ propulsion system is referred to as a power plant before it is geared to a specific airplane. It is assembled for test purposes only, and does not include a complete set of auxiliary components necessary for flight. 
INEL, TAN, HANGAR 629

HAER NO. ID-32-A

Page 21

particularly in the area of materials that would resist high temperatures and high radiation.

In November $1951 \mathrm{GE}$ said it could deliver a direct cycle aircraft ready to fly for $\$ 188$ million by May 1956 . The Air Force moved to make flight tests a goal of the ANP program, proposing formally ion April 1952 that ABC schedule flight testing in 1956 or 1957.40 Although AEC commissioners were skeptical

(remembering that the Lexington group had predicted it would take 15 years and cost $\$ 1$ billion), they accepted the proposal and directed that the program's objectives now include a flight demonstration. The demonstration would not use a ner girframe, but rather would modify and adapt an existing bomber. 4

Appropriations for various aspects of ANP work flowed to contractors situated in at least seven states. In addition to the two main competitors developing the direct and indirect cycle power plants, other research went towards the development of ramjets and other unmanned propulsive applications. The only work assigned to the reactor test site in Idaho was the ground test phase of GE's direct cycle program. ${ }^{42}$

${ }^{40}$ Lambert, p. 7 .

${ }^{41}$ Reirn in Gantz, p. 13.

${ }^{42}$ Research on ramjet nuclear-powered propulsion of missiles was the a joint project of the Air Force and AEC that began in 1955. Named the Pluto Project, research was undertaken at the E.O. Lawrence Radiation Laboratory, North American Aviation, Inc, the Marquardt Corporation, and Chance-Vought Aircraft, Inc. Tests took place at the AEC's Nevada Test Site.

The Rover Project, started in 1957, examined the use of nuclear power for the rocket propulsion of space vehicles. Initiated as a joint project of the Air Force and the AEC, the National Aeronautics and Space Administration replaced the Air Force as sponsor. Research was conducted at Los Alamos, at NASA's Lewis Research Center, and by Aerojet-General Corporation.

The Snap Program, also launched in the mid-1950s by the Air Force and the AEC, researched compact nuclear power systems for use as auxiliary power units in satelites and space vehicles. 
INEL, TAN, HANGAR 629

HAER NO. ID-32-A

Page 22

\section{PART FIVE}

\section{TEST AREA NORTH AND THE INITIAL TESTS}

General Electric laid plans to conduct its first heat exchange experiments. Before flight, ground tests would have to demonstrate that nuclear heat actually could run a turbojet engine. Conducting the ground tests, which at first would not include airframes, would nevertheless require a complete and elaborate test laboratory, fabrication plant, and a myriad of support functions. GE had to design nearly everything from scratch: operational, measurement, procedural, and control systems; training and safety routines; remote handling and installation procedures; and the buildings or other enclosures in which these--and the experiments themselves--could take place.

GE hired the Ralph M. Parsons Company of Los Angeles as the architect and designer of what GE would call its Idaho Test station. The experiments would open a brand new section at the remotest reach of the site, Test Area North, where noise and potential accidents would pose as little threat to other site activities as possible. The complex would have to be expandable, eventualiy accommodating a long aircraft runway, for example.

The Parsons Company designed an environment in which the first goals and ground experiments could be accomplished. The big difference between this airplane reactor and all the other reactors that had come before it was that this one would be mobile. Therefore, people had to be shielded rather than just the reactor. "This design philosophy may represent a significant forward step in the development of mobile reactors" wrote one of the GE engineers. 43

Personnel shielding proved to be one of the more ubiquitous features of architectural design. This first phase of the test facility had four major parts: an administrative service area, the assembly and maintenance area ( $A M$ ), the initial engine test (IET) area, and an engine test pad that could be moved back and forth between the assembly area and the test area. These activity areas would be connected to each other by suitably shielded roadways, tunnels, and railroad trackage, each designed to transport equipment, jet engines, or people in safe and logical paths from one area to another.

GE's contractor, the Utah Construction Company, broke ground

43 APEX-131, Nuclear Power Plant Testing in the IET, (Cincinnati: Aircraft Nuclear Propulsion Program, Aircraft Gas Turbine Division, May 1953), p. 5. 
INEL, TAN, HANGAR 629

GAER NO. ID-32-A

Page 23

on the $A$ \& building in February 1953. By September 1954, it was 98\% completed, and the other areas were more than halfway done. $A$ GE-designed shielded locomotive had arrived, the engine test pad had been taken over for operation, and two modified J-47 turbojet engines had been uncrated. "Contracts were being awarded for internal features such as the exhaust gas handling system. Engineers were testing various remote handling equipment. They tried out a stereo teleygision rig, for example, and decided it offered no advantages. 45

By Christmas 1955, serious operations were underway. Recruiters opened for business in Idaho Falls, hiring heavily in the craft and maintenance categories. Buses that hauled employees back and forth between the site and neighboring towns put Test Area North on their routes.

The engineers developed a master list of procedures, using an experimental GE engine, an $x-39$, at the test pad to stand in for the turbojets. On the evening of November 17, 1954, they ran the engine for the first time, checked its performance at the Site's elevation, and measured noise levels and noise protection arrangements. They tested various other mechanical equipment as it arrived, using the $X-39$ to break in and shake down parts and systems. Parts of the reactor, which had been built in Eyendale and disassembled for shipment to Idaho, began arriving.

The plan was to construct, assemble, repair, and modify the experiment in the $A$ \& building. It contained a variety of fabrication shops and laboratories. The metallurgical lab contained $x$-ray machines for inspecting welds; the radioactive

$44 \mathrm{~J}-47$ denoted a series of gas turbine aircraft engines produced by General Electric in the 1940 s and later. Various modifications had been installed in fighters and bombers such as the F-86 A, which established a world speed record of 670.981 miles per hour in 1948, the F-86 D, the FJ-2 Fury, the B-45, the B-47 A, and others. See Jane's All the Norld's Aircraft, 1954-55 (New York: Franklin Hatts, 1955.)

45 Aircraft Nuclear Propulsion Project, Engineering Program Report No. 13, (APEX-13), (Cincinnati: Atomic Products Division, General Electric, Sept. 1954), p. 10-11, 195. During the course of the project, GE produced several hundred technical papers and regular quarterly progress reports on ANP. These were named "APEX" and numbered in sequence. Hereafter, the quarterly reports from this series will be cited only by their APEX number and the date. See also Thumbnail Sketch 1956.

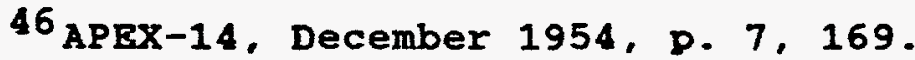


INEL, TAN, HANGAR 629

HAER NO. ID-32-A

Page 24

materials lab would examine spent fuel elements from the reactor and other radioactive samples. A Hot Shop with its shielded windows allowed for the remote handling of radioactive substances; a chemical lab handled other chemicals, and a photographic lab was available. "Cold" shops were equipped to repair jet engines, make and calibrate instrumentation, and assemble (prior to their initial test) the nuclear power plants that would be the subject of the experiments. This building was separated from the others by constructing it next to a natural ridge formation and shielding it with a 15-foot compacted earth embankment. 4

Once the reactor and the jet engines were deemed ready to run, they were assembled together on a moveable "test pad." The package could be enclosed by a special all-weather removeable aluminum building shell. This entire rig--reactor, engine, and housing-was loaded onto a specially constructed railroad flatbed (dolly) and hauled to the Initial Engine Test (IET) site a little over a mile away. A locomotive pushed the heavy assemblage on a 4-rail track to the test site, withdrew during the test, and then retrieved it when the experiment was concluded, hauling it back, now quiet, to the $A \& M$ building. To protect the locomotive operator and his passengers, the cab was surrounded by lead and water. The operator's shielded viewing window contained layers of oil and glass a total of five feet thick.

\section{PART SIX}

\section{REDIRECTION: DON'T FLY! FLY EARLY!}

While contractors and engineers transformed the sagebrush plain at Test Area North into a nuclear propulsion experiment, the original and early conflict over the ANP program erupted again in Washington. From the beginning, the debate had pitted the undeveloped state of reactor research against the Air Force's desire to "fly early." Iterations of this conflict occurred over and over between 1951 and 1961. Each renewal of the struggle brought fresh decisions that caused the ANP program to be "redirected," its goals restated, its budget accelerated or diminished, and its mission adjusted--and, the GE engineers would argue bitterly later, a loss of productive time to make real

47 APEX-15, March 1955, p. 10; see also Thumbnail Sketch, 1957, p. 11-12. 
INEL, TAN, HANGAR 629

HAER NO. ID-32-A

Page 25

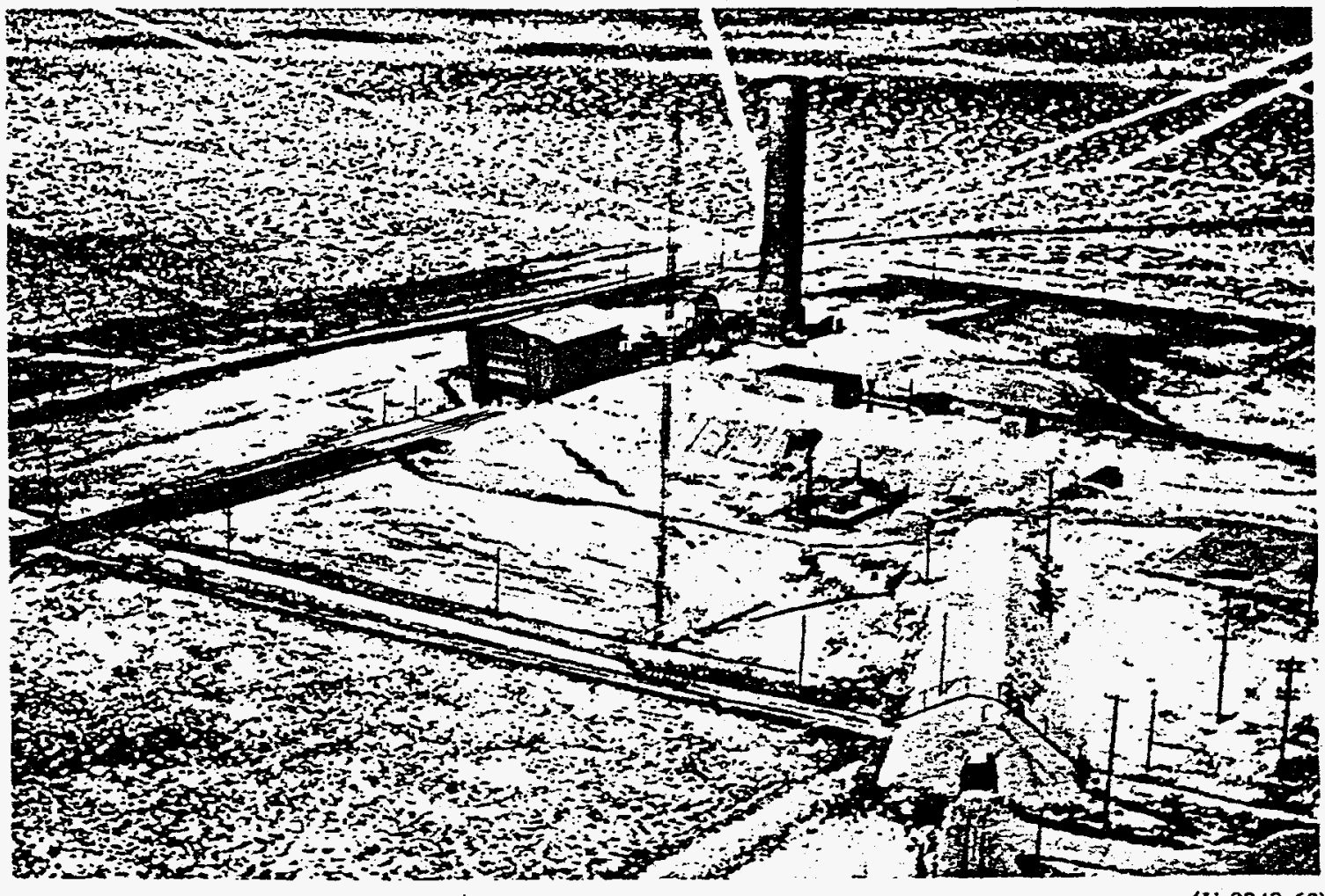

(U-3343-62)

Initial Engine Test (IET) facility. The reactor and engine test assemblies, mounted on a railroad dolly, were moved to the IET by a traction vehicle for power testing. The movable aluminum building served as weather protection, and the large unobstructed space which surrounded the reactor test assembly permitted shield and airscattering tests to be conducted. Poured concrete, 3 feet thick, and 14 feet of compacted earth shielded operating personnel in the control and equipment building, which was accessible by means of the 450-foot-long access tunnel shown in the foreground. The 150foot stack disposed of the exhaust gases, after they had been filtered to remove radioactive particles.

Figure 3. View of the Initial Engine Test Facility (IET). constructed for the Heat Transfer Reactor Experiments. Source: APEX-901, p. 156 . 
INEL, TAN, HANGAR 629

HAER NO. ID-32-A

Page 26

progress. 48

In summary, ANP program objectives changed as follows:

\begin{tabular}{|c|c|c|}
\hline & From & To \\
\hline Flight demonstration & April 1952 & May 1953 \\
\hline Applied research & May 1953 & Nov 1954 \\
\hline $\begin{array}{l}\text { Flight development } \\
\text { (Weapon System 125-A) }\end{array}$ & Nov 1954 & Dec 1956 \\
\hline $\begin{array}{l}\text { Experiment: no flight } \\
\text { objectives }\end{array}$ & Jan 1957 & March 1957 \\
\hline $\begin{array}{l}\text { Experiment: yes flight } \\
\text { objectives }\end{array}$ & April 1957 & Feb 1958 \\
\hline $\begin{array}{l}\text { Flight development in } \\
\text { militarily useful } \\
\text { aircraft }\end{array}$ & March 1958 & Oct 1958 \\
\hline $\begin{array}{l}\text { Development for space- } \\
\text { related mission }\end{array}$ & Oct 1958 & July 1959 \\
\hline $\begin{array}{l}\text { Research for reactor } \\
\text { experiments }\end{array}$ & July 1959 & $\begin{array}{l}\text { Termination in } \\
\text { March } 1961\end{array}$ \\
\hline
\end{tabular}

The details of the many redirections, the reasons for them, and their consequences were debated and discussed largely without observation by the public. Roughly, they reflected the relative rise and fall of power and influence among the major participants. The Joint Committee on Atomic Energy conducted over 35 "executive" hearings on the ANP program, closed to press and public, its deliberations classified. Contributing to the general debate was the fact that during these years, research and development on other propulsive systems using chemical fuels also made considerable progress, preempting some of the goals that had justified earlier research on a nuclear airplane. For example, the ability to control the precise trajectory of a (chemically fueled) missile armed with a nuclear warhead over a long (intercontinental) range improved remarkably during this time.

The first major redirection occurred in 1953 in the form of

48 These decisions and their impacts are narrated in detail in Appendix I of the Comptroller General's report. 
INBL, TAN, HANGAR 629

HAER NO. ID-32-A

Page 27

a cutback in funds. The airplane became one of many victims of President Bisenhower's desire to reduce federal spending generally and the Department of Defense budget in particular. His budget control technique placed a "budget ceiling" on the department. The Secretary of Defense, Charles Hilson, allocated the funds among the three services, and each service then had to prepare its budget, submitting requests over and above its allocation in a prioritized addendum.

WiIson was no supporter of the ANP project. He felt that the great rush to fly an airplane exceeded the science to support it and that the country would end up with a "bum airplane," which he characterized as "a great big bird that flies over the marshes... doegn't have much body or speed to it or anything, but it can fly." 49 The National Security Council decided in April 1953 to eliminate an atomic airplane as a requirement for national security. 50

This development distressed congressmen on the JCAE. To appease this committee and to solicit its support for other Department of Defense programs. Wilson did not entirely cancel the program. While no new federal funds were allocated for FY 1954. unallocated funds from previous years' budgets were authorized for continued expenditure. Naturally, a reduced level of funding slowed progress in the field.

However, the Air Force did not give up. It decided to define a specific "weapon system" that would extend the capability of the strategic Air Command. It asked GE to prepare a new program that would test a reactor in a prototype aircraft on the ground. Up to this point, GE had been evaluating two types of aircraft reactors, solid- and liquid-moderated. ${ }^{1} \mathrm{GE}$ dropped its work on the liquid-moderated in favor of solid. It also told the Air Force that the engines it had heretofore been working on were not suitable for a flying weapons system and that more effort would

$$
\begin{aligned}
& 49 \text { Lambright, p. } 8 . \\
& 50 \text { Comptroller General, p. } 127 .
\end{aligned}
$$

${ }^{51}$ A moderator is a substance that slows down the speed of neutrons set free in a nuclear reaction, but does not itself absorb them. Pure graphite (carbon) and deuterium oxide (heavy water) were typical moderator materials. See Philip Rogan, The Cosmic Power, Foundations of Nuclear Physics, Foundations of Science Library (London: Sampson Low, Marston, and Co., 1966), p. 85. 
INEL, TAN, HANGAR 629

HABR NO. ID-32-A

Page 28

have to be made in this area. 52

Looking toward the development of a complete weapons system (which includes not only the aircraft and its payload, but all of the related equipment, skills, techniques, and material, services, and procedures that create an instrument of combat capable of striking the enemy). GE asked the Parsons Company to plan an expanded facility at the Idaho site. Instead of testing merely power plants. GE was soon going to test an actual aircraft, arrange for crew training and transport, and develop systems for the repair and maintenance of a "hot" airplane upon its return from flight.

The Air Force called the project Heapons system 125-A. Parsons drew up plans for a new set of buildings at rest Area North: a facility to house and test an airplane, a shielded control and equipment building from which the plane could be managed and maintained remotely, and a stack thăf would discharge engine exhaust high into the air over the site. 53

In March 1955 the Air Force issued General Operational Requirement No. 81 defining the desired weapon system. It would have to deliver nuclear bombs to any target in the world, cruise at a speed of not less than Mach .9, and be able to sprint at supersonic speeds in combat zones. The system should be operational in 1963. A Department of Defense review group toured GE activities in Cincinnati and at the shield testing station at Oak Ridge and concluded that "the objective of achieving

practical and useful flight...probably augmented by chemical fuel during parts of the mission, seems more probable of attainment" than it had earlier in the program.

Congress authorized construction of the Flight Engine Test Facility (FET), its supporting buildings, and a runway in July 1955. Detailed design commenced in March 1956, and groundbreaking occurred in september 1957. At a gost of about $\$ 8$ million, the facility was ready in July 1959.55

52 Comptroller General, p. 132.

${ }^{53}$ Comptroller General, p. 132 .

54 Comptroller General, p. 133. See York, Race to Oblivion. for a critique of the AEC and Air Force practice of sending ad hoc review groups to contractor sites rather than established committees with more continuity of knowledge.

55 Comptroller General, p. 138 . 
INEL, TAN, HANGAR 629

HAER NO. ID-32-A

Page 29

The 23,000-foot runway (4.36 miles), although partially designed, was never constructed. ${ }^{56}$ After a number of study groups evaluated the matter, the AEC decided in December 1958 that neither the NRTS nor any other AEC installation could be used for an ANP test site. "The decision not to use NRTS for the flight test base gave due regard to prior Government

expenditures," but the AEC determined that "these were more than outweighed by the potential risks involved." 57 Rather, the AEC decided that nuclear test flights should originate from an island or coastal station and $f I y$ only over the ocean.

Construction continued on the Flight Engine Test Facility despite the certainty that it could not be used as a flying test base because "the facilities remained an esseptial part of the ANP program" for ground testing and training. 58 There would, after all, eventually be a prototype aircraft that would require ground testing before it was hauled to a coastal base for flight tests.

In December 1956, the Defense Department canceled the Weapons System 125-A program. The scientists, momentarily with the upper hand in the perennial conflict, reported, "While the present state of the reactor art is encouraging, it does not conclusively demonstrate that a useful vehicle can be built." 59 This report bolstered other efforts to reduce military spending. Later in December, preliminary results of GE's first heat transfer experiments indicated that the temperature of the air exiting the reactor was going to be lower than expected.

Despite their disappointment in the cancellation, the Air Force/Joint Committee/Contractor groups marshalled their forces within just a few months and prevailed in another effort to make "early flight" an ANP objective--even though the achievement

56 "Proposed ANP Runway Area," Drawing No. 7-ANP-001-2 2/2, and "ANP Runway Profile," 7-ANP-001-3. Shown to author by Bud White, INEL. Copies are also available at Record storage Center, Central Facilities Area, INEL.

57 Comptroller General, p. 52, quoting the ABC's general manager who wrote an explanation of the AEC decision in 1962 .

${ }^{58}$ Comptroller General, quoting a memorandum from the Deputy for Development, Research and Development Air Force, september 12,1962, p. 39 .

59 Comptroller General, p. 138. The quotation is fron an October 1956 report by the Air Foce Scientific Advisory Board Nuclear Panel on USAF Aircraft Nuclear Propulsion Program. 
INEL, TAN, HANGAR 629

HAER NO. ID-32-A
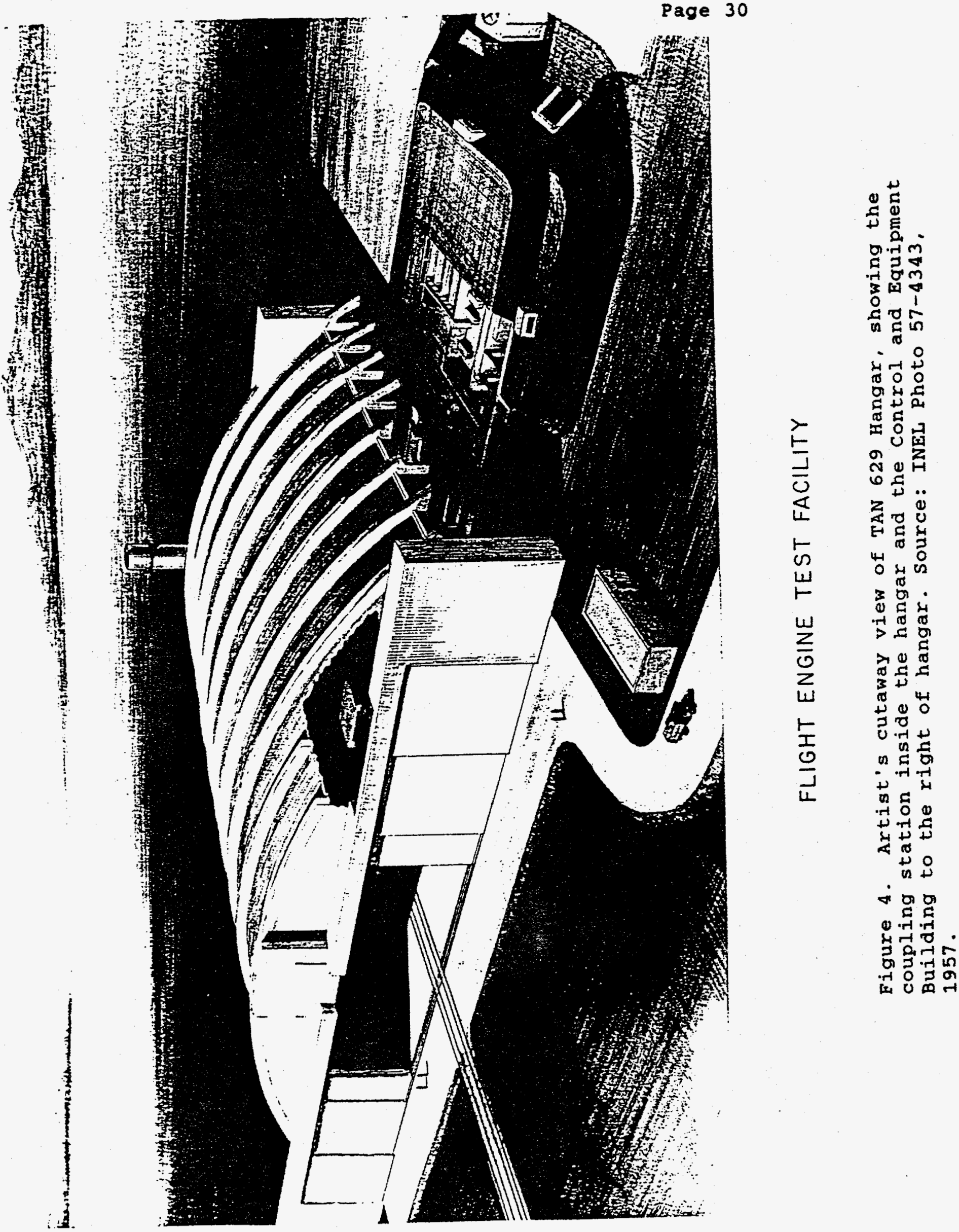
INEL, TAN, HANGAR 629

HAER NO. ID-32-A

Page 31

would be at levels of performance too low to be militarily useful. ${ }^{60}$ Meanwhile, the impact of this (and other) redirection of the ANP program always took months of follow-up consultation and re-negotiation between contractors and the AEC and the Air Force. Decisions were rarely, as the Comptroller General pointed out in a post-cancellation review, formalized immediately upon high-level decisions. 1 out in Idaho, it must have seemed that if they just waited awhile, the weather would surely change.

Despite the rocky road in Washington, at the time the Flight Engine Test facilities were designed all parties at the Site expected that they were preparing ultimately to send a nuclearpowered aircraft down an Idaho runway for a flight test. Upon its return to the base, they would receive it, record test data, debrief and decontaminate the crew, service both the nuclear and non-nuclear components of the machine, and then prepare plane, pilots, and crews for another test.

Clearly, this scenario called for an airplane hangar. It would look like many other large hangars in the country, but its details would account for its unique nuclear occupant.

\section{PART SEVEN}

\section{DESIGNING THE FET: TAN 629 HANGAR}

The GB operators at Idaho developed the design criteria for the building in which flight engine tests would occur.62 These were the basis for highly detailed drawings that the Parsons Company then prepared. 63 Because the project was classified, the design document omitted precise operational requirements, but used general terms to describe the purpose of the research to be conducted in the facilities.

60 York, p. 66 .

${ }^{61}$ Comptroller General, p. 6 .

${ }^{62}$ D.J. Blevins et al, Flight Engine Test Facility Design Criteria, APEX-225, (Idaho: GE ANP Department Idaho Test Station, December 16. 1955). Hereafter cited as FET Design Criteria.

${ }^{63} \mathrm{~A}$ set of Parson's original drawings (architectural, structural, piping, heating and ventilation, miscellanious specialties, and electrical) are located in the Central Facilities storage Warehouse at INEL in Drawers $A-1$ through $A-7$. 
INEL, TAN, BANGAR 629

HABR NO. ID-32-A

Page 32

Before actual flight, the engineers needed to solve several significant procedural and engineering problems. The Flight Engine Test facilities had to accommodate the following major test activities:

1. Ground test aircraft nuclear power plant packages (reactor plus engines) and systems on test stands.

2. Establish and test a means of transferring power package unit into and out of the airframe; solve control and service connection problems prior to the design of operational facilities.

3. Determine adequacy of the design of the power package installation, its attachment to the airframe, and the integrity of the airframe under the stresses of operation. handling.

4. Establish operational procedures for power package

5. Provide test facilities where power package can be operated either from a remote control room or from the aircraft cockpit.

6. Provide a facility which can be converted with ease to perform the functions of auxiliary ground handling installation. 6

The scientists had made some assumptions about the dimensions and characteristics of the airframe. Each power package would need to be handled as a unit. A maximum of four engines per plane might be slung under the wing close to the fuselage. Chemical fuels would be auxiliary to the operation. The plane would weigh at least 600,000 pounds. It would extend 135 feet from wing tip to wing tip, be 52 feet wide at the tail be 205 feet long, and be 53 feet high or higher at the tail. 65

The AEC had established dose limits on the amount of radiation to which personnel could be exposed. For example, in an extreme emergency, a maximum of 100 rem of exposure could be allowed in a short period of time. It was expected that any personnel who received excessive amounts would be transferred to

\footnotetext{
64 APEX-18, p. 195

65 APEX-18, p. 196 .
} 
INEL, TAN, HANGAR 629

HAER NO. ID-32-A

Page 33

non-radiation work to avoid further exposure. ${ }^{66}$ Thus the designers had to consider these limits in preparing a safe working environment.

With the above goals in mind, the first issue was the location of the test facility. Because the aircraft would, after the first ground test or flight, be a source of radioactive contamination of various kinds, it had to be isolated. It should be located at least 8,000 feet west of the main administrative area. The exact location would be determined after a radiation field analysis could be done. 67

The next issue was the clear space the test facility ${ }_{6}$ ould provide. GE specified dimensions of 360 feet by 310 feet. (Clear space dimensions later were modified to 320 feet by 234 feet.) Although a "cantilevered hangar" was considered as a design option, Parsons chose a conventional barrel-ribbed vault hangar building.

The design criteria specified that "new facilities shall be similar in construction and appearance to existing facilities" at other places on the NRTS site. The NRTS was no place for architectural experiments, delicate design, or unusual construction materials. The AEC (and later its successor agency, the Department of Energy) sought to economize by stocking as many standard materials and spare parts as possible. Unique construction materials, surface cladding, or shapes were undesirable because they complicated routine maintenance and servicing. ${ }^{69}$ Indeed, the FET barrel vault roof is a unique design--at least on the site--and has challenged the maintenance staff for years because of a chronically leaky roof.

To provide for the safety of personnel and crews, the

${ }^{66} \mathrm{~A}$ rem is a measurement of the amount of energy the body's tissues receive from radiation. The maximum annual whole body exposure allowed annually was $12 \mathrm{rem}$, or $3 \mathrm{rem}$ per quarter. See APEX-18, p. 196; also J.R. Horton, et al, occupational Radiation Exposure History of Idaho Field office operations at the INEL, EGG-CS-11143, October 1993. The safety requirements given to Parsons were published in ITS-GE-ANPD Personnel Protection standards.

67 FET Design Criteria, p. 1.

68 FET Design Criteria, p. 9 and drawing IDA-FET-602 at p. 39 of same report.

${ }^{69}$ FET Design Criteria, p. 7 . 
INEL, TAN, HANGAR 629

HAER HO. ID-32-A

Page 35

designers realized that radiation levels would be different in different parts of the complex. They had to forecast likely hazard levels and supply shielding accordingly. Shields typically consisted of concrete or earth cover, installed at specific thicknesses and density or compaction. Shielded viewing windows were specified at Hot Cells and other strategic places throughout the complex.

The tests would involve the production, transfer, and filtering of noise, heat, and intake and exhaust air. The building would thus have to accommodate vast mazes of piping and conduit, noise abatement materials, fire protection systems, cooling water systems, conveyance of hot and "hot" (contaminated) water to disposal tanks, storage of various gases, and the control of dust and explosions. All systems, including the supply and distribution of electrical power, had to be extremely reliable and operate in all weather conditions. Design capacities and margins of safety had to be larger than was usual in normal industrial practice. While cost was an issue, reliability was not to be sacrificed for minor savings. 7

Looking ahead to the arrival of an airplane at the site, the designers anticipated that the craft would come to a stop on the runway and then be towed into the hangar. The craft might come home in a variety of conditions-whole or damaged, potentially unstable or dangerous, and definitely radioactive. A variety of mobile equipment would therefore be required. GB informed Parsons that GE itself would design these items: mobile air supply, duct couplers, mobile package positioner, railroad dollies, decontamination apparatus, mobile remote manipulators. GE would also build a shielded tow tractor, a personnel carrier, and a control vehicle. 7 The project was canceled before GE managed to produce all of these items. It did make a shielded tow tractor, named the "Beetle." Its purpose was to remove the reactor and power plants from the aircraft. Almost finished when the program was terminated, $\mathrm{GE}^{\mathrm{E}}$ completed it and put it to work in its nuclear rocket program. 72

Remote control, measuring, and data analysis would need to

70 FET Design Criteria, p. 8.
$71_{\text {FET Design Criteria, p. } 9 .}$

72 G. Thornton, A.J. Rothstein, ed D.H. Culver, Comprehensive Technical Report, General Electric Direct-Air-Cycle Aircraft Nuclear Propulsion Program, Program Sumary and References, APEX-901, (Cincinnati: GE Nuclear Materials and Propulsion Operation, June 28, 1962), p. 160. 
INEL, TAN, HANGAR 629

HAER NO. ID-32-A

Page 36

operate from a Control and Equipment building. (This building eventually was designated as TAN 630.) This facility would have to be an integral part of the complex design, but well shielded from radiation hazard that could come from all directions. The site also required an exhaust filter and stack system. The fourtrack railroad lalready a part of the Initial Bngine Test facilities) would connect the hangar to the turntable and thence to the assembly and maintenance area. The reactor and other heavy components of the aircraft could be dismantled and hauled to the hot shop for examination and maintenance. To provide safe passage for personnel between the hangar and the administrative area, the roadway would be shielded. Close to the hangar yould be a decontamination byjlding, a nuclear service building, and a transfer station. 73

In an actual test, the hangar's front doors--remotely operated--would open the full width of the building. Once the aircraft was towed into the hangar, it would be parked at a place on the hangar floor especially reinforced to hold the weight of the aircraft. Here the crew would discharge directly from the aircraft through a hatch and down to a special service area on a lower floor. They would then pass through decontamination chambers, medical examination rooms, and other services. From there a tunnel four feet wide by seven feet high would lead to the Control and Equipment building. Other branches of the tunnel would lead to the shielded coupling station, to shielded viewing stations, and to a position under the four-rail track just outside the entrance to the building. The locomotive operator could ascend and descend through a hatch directly into the shielded $\mathrm{cab}$ of the locomotive from this position. Naturally, all the tunnels had to have adequate drainage and ventilation. The roof of this last tunnel had to be constructed so that additional hatches coyld be added in the future along the entire length of the track.

Another tunnel would connect the Cable Roon in the Control and Equipment building to the service area. It would provide for piping and conduit and be sloped for drainage. If it would assist the causf of shielding, the tunnel might be of "labyrinthine" design. 75 Engineers could look into the hangar through a protected window--an important need in case of an accident or other emergency.

${ }^{73} \mathrm{FET}$ Design Criteria, p. 11.

${ }^{74}$ FET Design Criteria, p. 11.

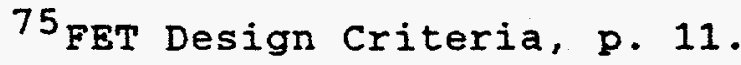




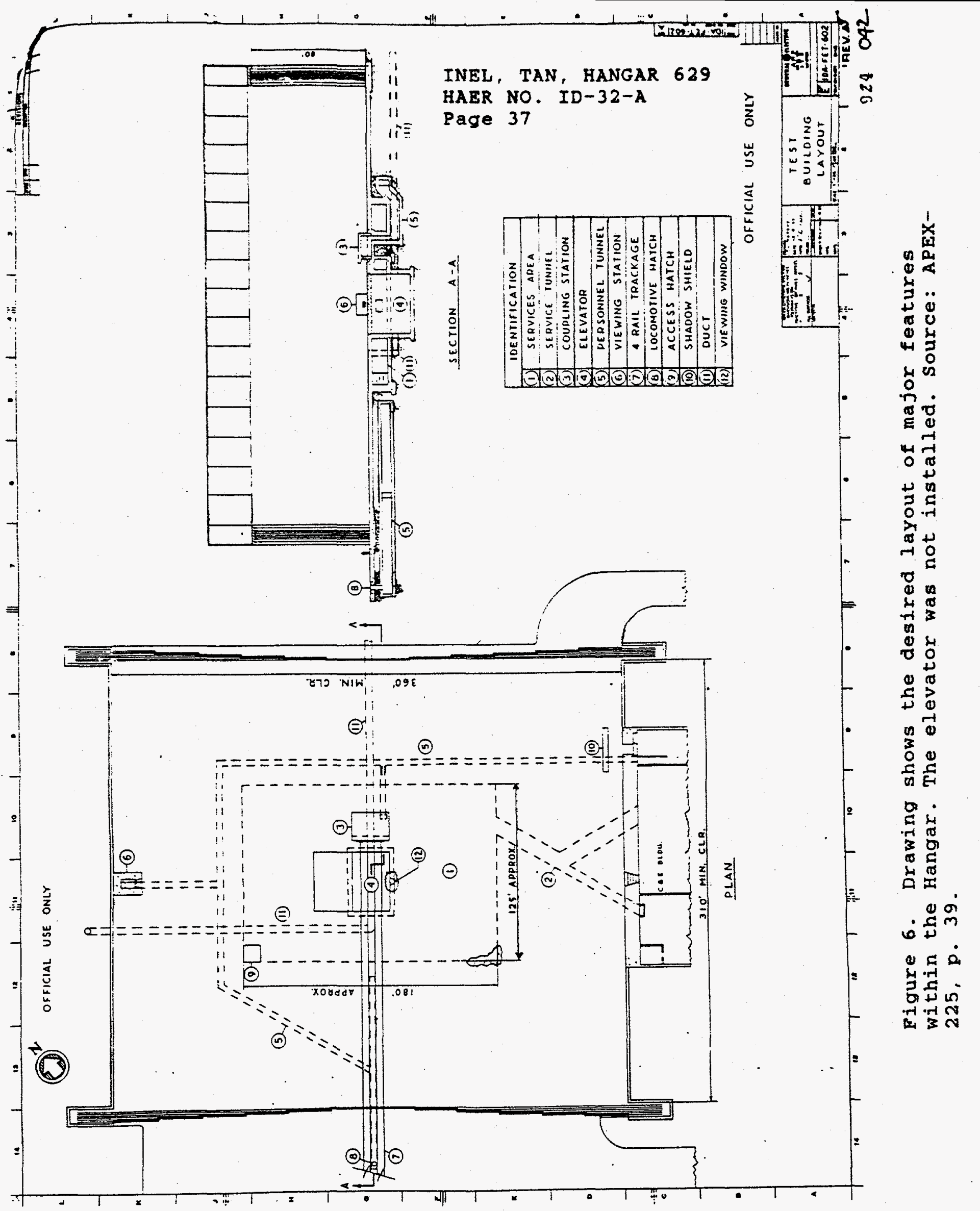


INSL, TAN, HANGAR 629

HAER NO. ID-32-A

Page 38

The hangar floor would have to be of "grid-type" construction, particularly over the service area so that it could be pierced for insertion of conduits, hoses, and the like. The four-rail track would be flush with the floor, and the floor would accommodate drains for the contaminated vastes resulting from spills or the washing of the aircraft.

A hydraulically operated elevator of "extreme" reliability would be situated so that a load, such as the power plant of the airplane, could be lowered to a below-ground service area. The elevator cover, also hydraulically operated, vould be constructed to function as a radiation shield. The walls in the elevator shaft would contain two viewing ports and numerous plugged ports for potential future use. Drains and valves in the floor of the shaft would discharge either contaminated or uncontaminated wastes to separate holding tanks. Ducts into the shaft would provide for "aftercooling" of the wastes. Another small elevator would copfect one of the personnel tunnels to the coupling station. 76

A coupling station, a device previously implemented at the Initial Engine Test facilities, was to be positioned on the hangar floor. This station would plug the engine into its sources of fuel, air, water, electricity, and control leads to the Control and Equipment building and to discharge ports for various waste products. It was equipped for remote coupling and uncoupling of all service leads. The coupling station was part of a larger system that operated in conjunction with the railroad flatcars and a similar coupling station at the outdoor test pad site. 77 made it possible for engineers to work on more than one engine at a time. They could check engines at the test pad for shipment damage, for example, while conducting other tests on an assembled power plant in the hangar at the same time. 78

Although equipped with nuclear power, the airplane would need conventional maintenance as well. Thus the hangar had to provide space for supply areas and tools for changing tires, servicing hydraulic and lubricating systems, testing electronic systems, checking instruments, refueling with chemical fuel, and the like. The floor would be reinforced at jacking points. Plenty of ceiling space would be needed for overhead bridge cranes that

76 FET Design Criteria, p. 11-12.

77 FET Design Criteria, p. 12-13.

78 APEX-131, p. 20 . 
INEL, TAN, HANGAR 629

HABR NO. ID-32-A

Page 39

could lift five to ten tons over an airframe. 79

On the main floor of the hangar a "shadon shield" would be positioned in front of the hallway connecting the hangar to the Control and Equipment building. Constructed of concrete, this shield would help block the force of explosions and fissionable materials from entry to the Control and Equipment building.

The Control and Equipment building would house the brains of all operations at FET. Here, engineers would control the power plant, record and analyze data, receive radiation or fire alarms, operate remote switches and controls, run the communications center, and operate various laboratories. This reinforced concrete building would be shielded with an earth cover or, where it interfaced with the hangar, thick concrete. The building would have one floor at ground level, but $G E$ also considered--and built--a subgrade floor as well. The functional parts of the building included the control and data room and a change room big enough to handle up to 60 male personnel on a one-shift basis. Equipment included hand and foot counters, lockers, clothes hampers, showers, and toilets. Elsewhere a women's lavatory acknowledged that there might be as many as "six women per shift" somewhere in the control building.

A counting room would "provide attenuation for an inside background radiation level of not over. $10 \mathrm{mr}$ per hour" during maximum power test operations. Other areas provided for flight operations, technical briefing areas, a jet fuel transfer room, a boiler room, a diesel generator room, instrument repair area, the cable room, and interchange areas between the shielded roadway and the building. A completely equipped "emergency kitchen" was to be stocked to feed thirty people for 72 consecutive hours on an emergency basis.

The exhaust and filtering systems were expected to be one of the most costly features of the FET complex, consisting of ducting, filters, couplings, support foundations, valves, manifolds, and monitoring systems. The exhaust stack would be similar to the 150 foot stack already in existence at the IET area. Electrostatic precipitators would remove dust (to which radioactive particles tended to cling) from exhaust air before it went up the stack. 81

$$
\begin{aligned}
& { }^{79} \text { FET Design Criteria, p. } 14 . \\
& 80 \text { FET Design Criteria, p. } 15-21 \text {. } \\
& 81 \text { APEX-37, p. } 147 .
\end{aligned}
$$


INEL, TAN, HANGAR 629

HAER NO. ID-32-A

Page 40

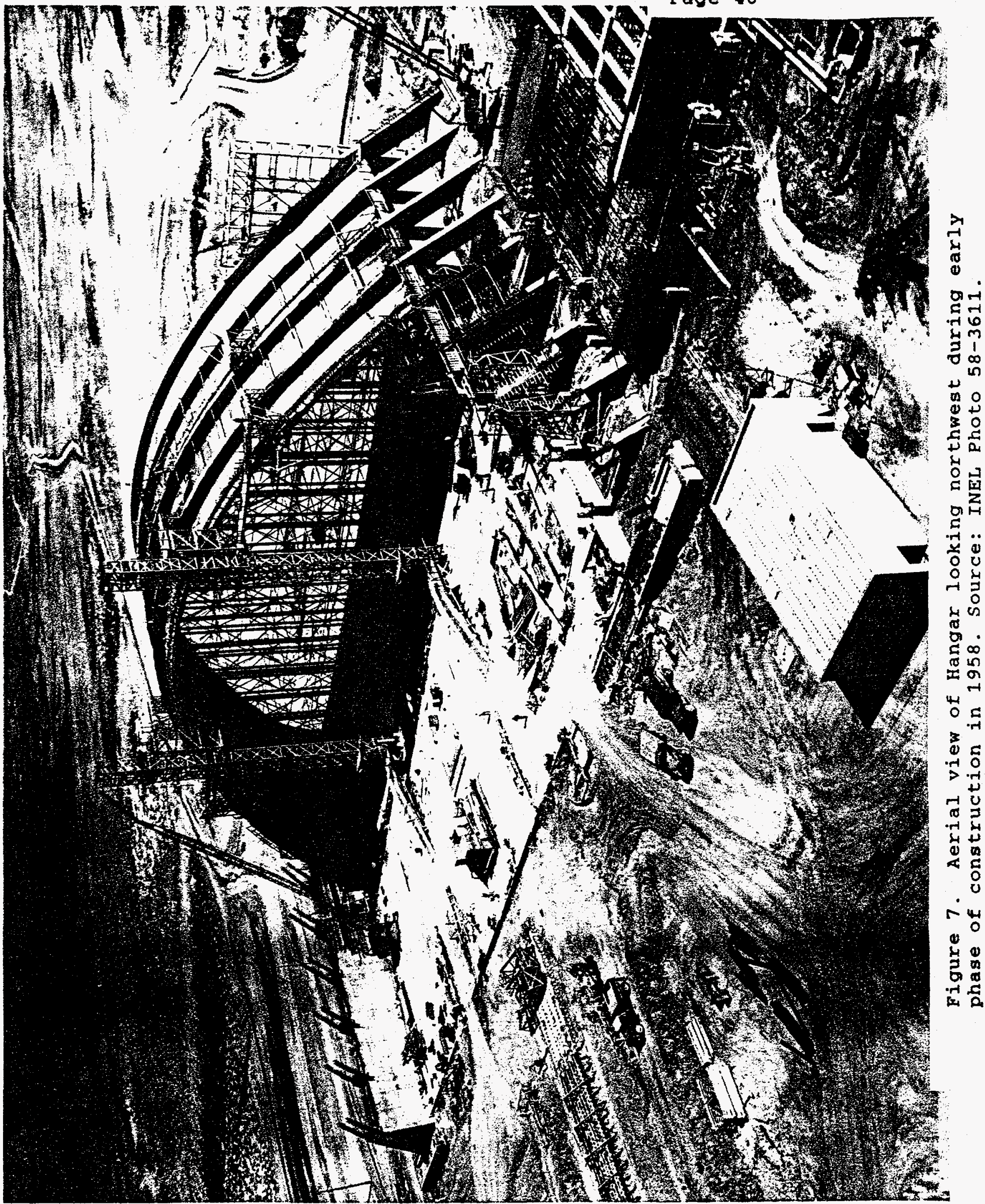


INBL, TAN, HANGAR 629

HAER NO. ID-32-A

Page 41

Where personnel were to transfer between shielded and unshielded functions, a transfer station would be equipped to decontaminate both personnel and equipment, provide indoor and outdoor storage for various service equipment, and provide for parking and servicing of the various mobile equipment such as the mobile tow tractor. It would have a high bagy area for cranes, change rooms, showers, and a guard office. 82

Finally, room had to be found around the immediate area for tanks and pumps to store fuel oil, diesel fuel, lubricating oil, jet engine fuel, process water, and fire protection water. A weather monitoring system equipped with leads to the control building would constantly surveil wind speed and direction and other factors at all times during operations and in case of accidents when radioactive materials were released into the atmosphere.

As was usual at all experimental complexes at the NRTS, security and safety fencing and emergency security lighting with standby power girded the project area.

To the Test Area North installations at the Initial Engine Test complex and the Flight Engine Test rould be added one additional major feature: a Shield Test Facility. Located well away from all the other facilities, this "swimming pool" had two compartments into which reactors could be submerged for various shielding tests. Near the pool was a platform and a gantry crane for "in air" tests. A control building would serve both the pool
and the platform. 4 .

In April 1957, after Parson's design work was completed, the Idaho Operations Office of the AEC invited construction bids. Seven companies responded. The winner, announced on June 5, 1957, was a partnership consisting of Howard $S$. Wright Company of Seattle, D.L. Cheney of Seattle, and $S$. Birch and Sons Company of Great Falls, Montana. The Idaho Falls office of the Building and Trades Council, having been put on notice nearly a year earlier,

82 FET Design Criteria, p. 23.

83 FET Design Criteria, p. 26-27.

84 APEX-217, Design Criteria: Shield Test Facility (Idaho Falls: General Electric Aircraft Nuclear Propulsion Department, Idaho Test Station, April 23, 1956), p. 5.

85 "Test Facility To Be Added at Nuclear Air Project; $\$ 6-7$ Milion Cost Seen," Post Register, April 19, 1957. 


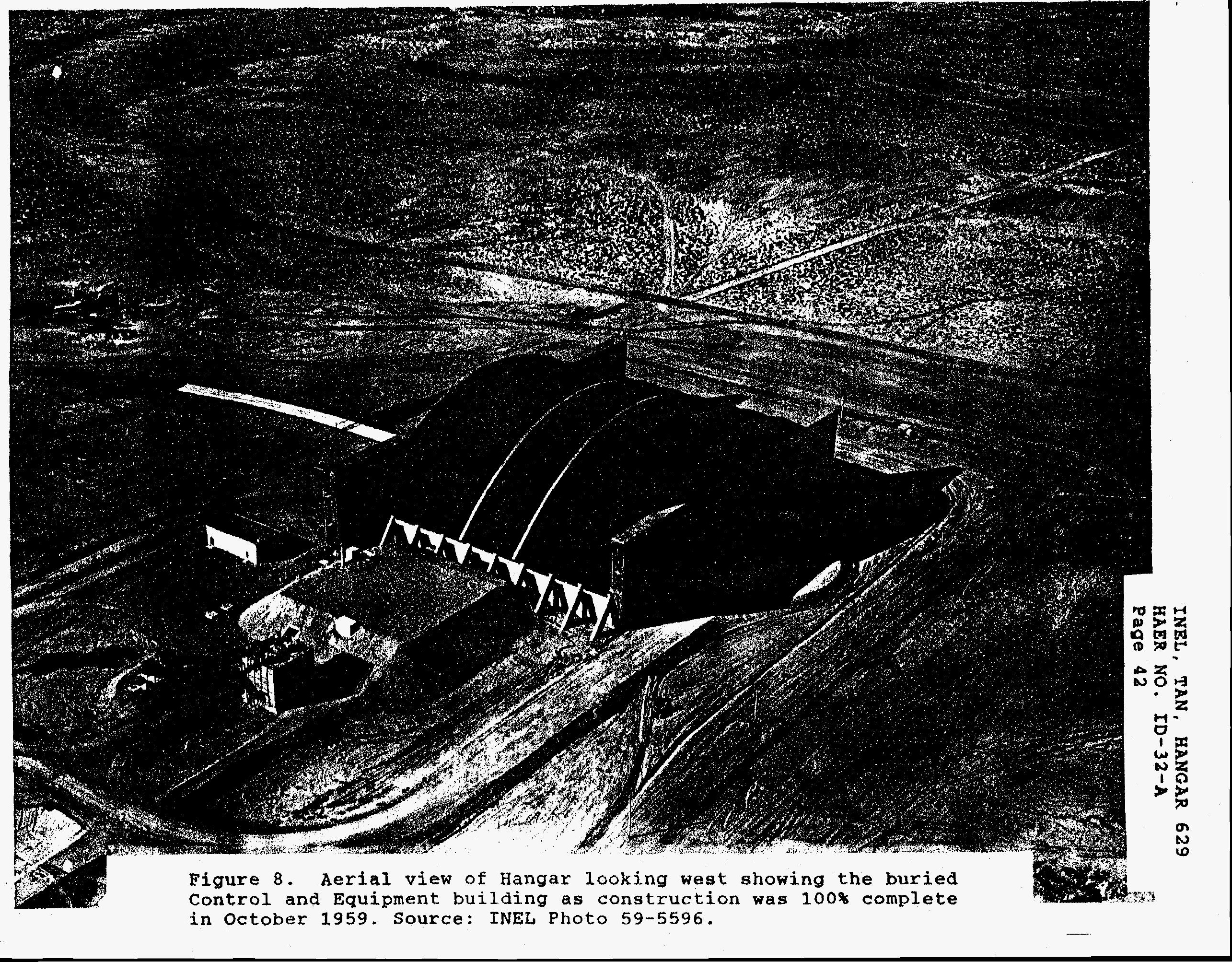


INEL, TAN, HANGAR 629

HAER NO. ID-32-A

Page 43

was ready with 500 construction workers. ${ }^{86}$ They went to work and the Flight Engine Test facjlity was ready for occupancy in late 1959. It cost $\$ 8,061,000.87$

By this time the ANP program had been drasticly "redirected." GE was ordered after JUIY 1959 to restrict its work to research for high temperature reactor experiments. Flying early was off the agenda. The hangar building, identified as TAN 629, was without a mission. It never saw a nuclear-powered airplane or test engine.

\section{PART EIGHT}

\section{THE ANP EXPERIMENTS}

Despite an uneven flow of funds and continuing redirection in their mission ordered from washington, GE's team of scientists and engineers in Ohio and Idaho managed to conduct several ground experiments advancing the cause of an atomic aircraft.

While the FET hangar was under design and then construction, the scientists and engineers already occupying the Initial Engine Test Facilities proceeded with their program of applied research. Readers interested in a more comprehensive description of this research may consult program Summary and References, a repgrt produced by GE in 1962 after the ANP program was canceled. ${ }^{88} \mathrm{~A}$ brief summary is provided here because the research contributed a broad spectrum of new knowledge about materials, shielding, reactor operations and design, and power plant operation and design--all supporting directly the objective of militarily useful flight--even though none of it took place at the FET hangar building. Much of this knowledge later found applications in many other frontiers of nuclear research.

The ANP Idaho group conducted three major ground experiments involving the operation of turbojet engines on nuclear power. Each experiment was in fact a series of tests conducted over a period of several months.

86 Press release, ABC Idaho Office, June 5, 1957, Dworshak Papers, Box 73, File: Legis AEC--Idaho Releases; and "Area to Supply 500 on Reactor Work," Idaho State Journal, May 4, 1956, p. 2 .

87 Comptroller General, p. 5.

88 see Note 68 for full citation. 
INEL, TAN, HANGAR 629

HAER NO. ID-32-A

Page 44

Heat Transfer Reactor Experiment No. 1 (HTRE-1) $^{89}$

The HRTE-1 reactor went critical on November 4, 1955, for tests prior to connection with the engines. On December 30, 1955 , it went critical while the turbojet engine pumped air through it. Maximum power operation was at 60 watts. ${ }^{9}$ The reactor used nickel-chromium, uranium-oxide-dispersion fuel elements, with water as the moderator and structural coolant. This was the first time that heat from a nuclear power reaction exclusively operated a J-47 turbojet engine. Measurements and additional tests continued through January 1957. The plant accumulated a total of 150.8 hours of operation.

The components of the experiment included the reactor, radiation shielding, instrumentation, and two engines, either of which could be operated by the reactor. For this initial test, the engineers made no attempt to restrict the size or weight of the assembly to approximate a flight version. They designed it large deliberately to make access as easy ess possible and to accommodate test and monitoring equipment. 91

This experiment demonstrated the feasibility of nuclear turbojet operation with a direct-air cycle reactor. It was the first known operation of a high-temperature, gas turbine engine on nuclear power. About this time, GE decided that a one-reactor, two engine configuration offered the best thrust-to-weight ratio contrasted with other configurations. Data concerning gamma radiation was sent to the shield test group at oak Ridge for analysis. More radiation was produced than what had been predicted, which meant that additional shield weight would have to burden the aircraft unless ways could be found to reduce it. Ensuing studies considered the use of depleted uranium as a component of the shield, but then rejected it because high heat caused the metal to warp.

The major disappointment with the test was that the reactor did not heat the engine air to the expected high temperature. Nevertheless, after the first run had proven the principle, the test team cheered each other and went to celebrate at the nearest

${ }^{89}$ Descriptions of the HTREs are in APEX-901, p. 19.

90 APEX-18, p. 7 .

91 "General Electric ANP Department Completes Testing of Heat Transfer Experiment No. 3." Press release issued by AEC Idaho Operations office, January 27, 1961. Copy in Dworshak Papers, Box 122-B, File: Atomic Energy Commission, Idaho Press Releases. 
INEL, TAN, HANGAR 629

HAER NO. ID-32-A

Page 45

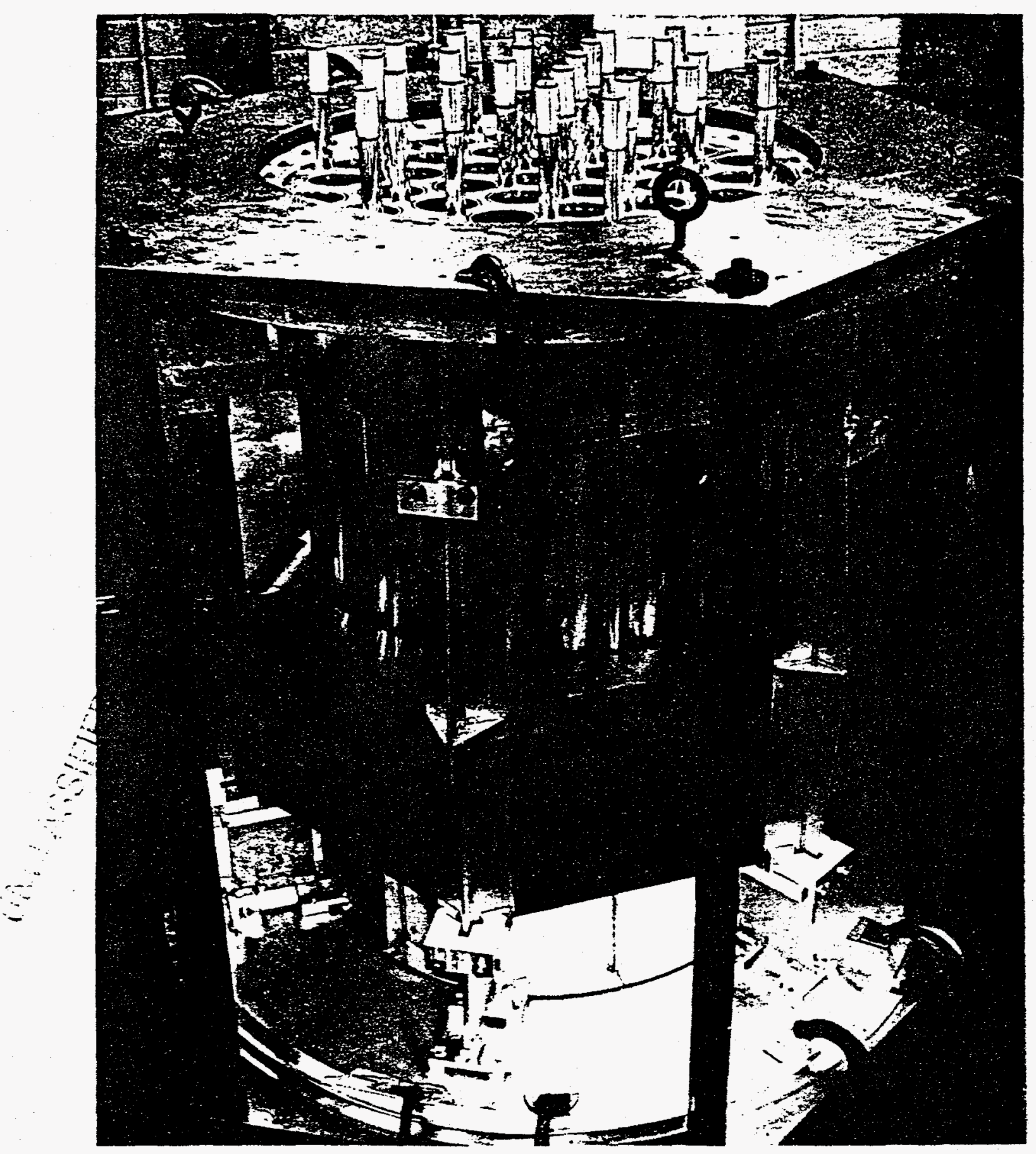

Figure 9. The HTRE-1 reactor under construction. Source: APEX 901, p. 38 . 
INEL, TAN, HANGAR 629

HAER NO. ID-32-A

Page 46

bar, which was a few miles away off-site at Mud Lake. 92

HTRE-2

The engineers next desired to conduct advanced tests on the impact of temperatures up to 2,800 degrees $F$. for sustained periods of time (and of temperatures at even higher temperatures for shorter periods of time) on various materials within and near the reactor. They modified the reactor by creating a center hexagonal hole into which they could insert a series of different metallic fuel elements and try them out under various operational conditions. This series of tests began in July 1957 and eventually accumulated 1,299 hours of nuclear operation. The inserts combined metallic fuel elements with air-cooled hydrided zirconium moderators and beryllium oxide fuel elements for use in ceramic reactors.

One of the many tests was an experiment to determine the radiological hazard if fission products in an airplane's reactor were to be accidentally released. Naming the test operation BOOT ("Burn out One Tube"), the engineers arranged to restrict the air flow through one of the fuel elements. Lack of coolant would cause the fuel to melt or burn and release fissionable materials. Before the test, they situated air sampling stations, laboratory rats, and milk cows downwind of the exhaust stack. When the experiment was ready, a valve shut off the air supply and meltdown began. The temperature of the fuel rose at a rate of 70 degrees $F$. per second. At about 8 seconds, the reaction started losing power, and at 15 seconds, the reactor scrammed (automatic shutdown when a condition reaches preset controls). However, the loss of reactivity overwhelmed the system before it scrammed, a sequence of events that surprised the experimenters. Meanwhile, uranium and other products left the exhaust stack as expected. During the next week, the analysts examined fallout pafferns as they impacted the animals, sagebrush, and air samples.

HTRE -3

HTRE-1 and HTRE-2 were designed with the reactor sitting atop the engine. This one placed the components in a horizontal arrangement more representative of what would be required in an aircraft. The new reactor core used metallic fuel elements in

92 Tierney, p. 50 .

93 APEX-445, Final Report, First Meltdown Experiment (Operation BOOT) (Cincinnati: General Electric Atomic Products Division, January 2, 1959), p. 9-43, 65. Several pages in this (now-declassified) report were deleted, the only such example of deletion in any of the reports or documents consulted for this HAER study. 
INEL, TAN, HANGAR 629

HAER NO. ID-32-A

Page 47

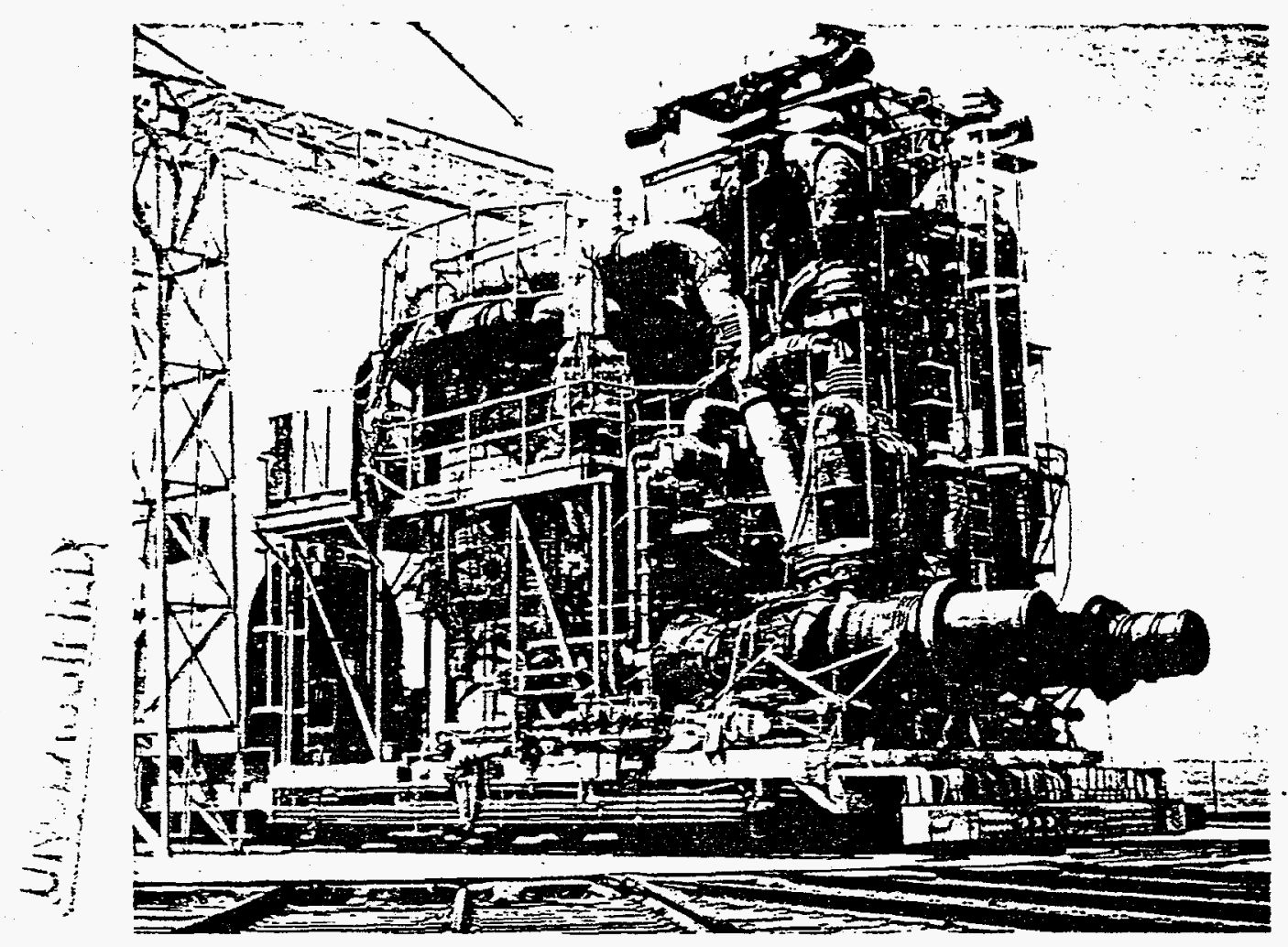

Figure 10. Assembly for Heat Transfer Reactor Experiments. Note leads for exhaust and other services on panel at lower right. These mated with a coupling station at the test pad. Source: APEX-901, p. 34 . 
INEL, TAN, HANGAR 629

HAER NO. ID-32-A

Page 48

concentric rings and a solid moderator. Operated at 2,000 degrees F., it was cooled by air provided by the modified $\mathrm{J}-47$ engines. For the first time, the experiment ran the two engines at the same time on nuclear energy. Begun in september 1959, HTRE-3 continued through December 1960. Towards the end of the experiment, the project attained another milestone when the two engines were started using chemical fuel, brought to a normal operating range, and then switched to operation on nuclear power. since a future aircraft would probably have to make such transitions for various operational reasons, this test provided data useful in future aircraft design. The longest period of HTRE-3's continuous operation was 65 hours, with an additional accumulation of 81 other hours at full power. 94

This experiment helped GE decide that the future aircraft would probably be configured with two nuclear reactors, each operating two engines.

$\frac{\text { HRTE }-4}{\mathrm{~A}}$

A fourth experiment was proposed using beryllium oxide fuel tubes. However, by that time other research led to a decision to develop a prototype propulsion system incorporating the ceramic reactor designs and components that had already been developed. The experiment was canceled.

The HTRE tests proved that nuclear power could propel a turbojet. Early findings led to continuous refinement in fuel elements, materials, and shielding methods. This report can do little justice to the breadth and depth of the scientific effort involved in the ANP enterprise.

\section{PART NINE}

\section{TERMINATION OF THE ANP PROGRAM}

On March 27, 1961, Dr. Mils C. Leverett, manager of General Electric's ANP Department, gave a press interview as he prepared

94 "General Electric ANP Department Completes Testing of Heat Transfer Experiment No. 3." Press release issued by AEC Idaho Operations office, January 27, 1961. Copy in Dworshak Papers, Box 122-B, File: Atomic Energy Commission, Idaho Press Releases. See also "HTRE - 3 Completes 120 Hours of Operation," GE News Idaho Test station, Aircraft Nuclear Propulsion Department (April 1, 1960; Vol. 5, No.7), p. 1. Issue found in Dworshak Papers, Box 112, File: AEC Idaho Plant. 
INEL, TAN, HANGAR 629

HAER NO. ID-32-A

Page 49

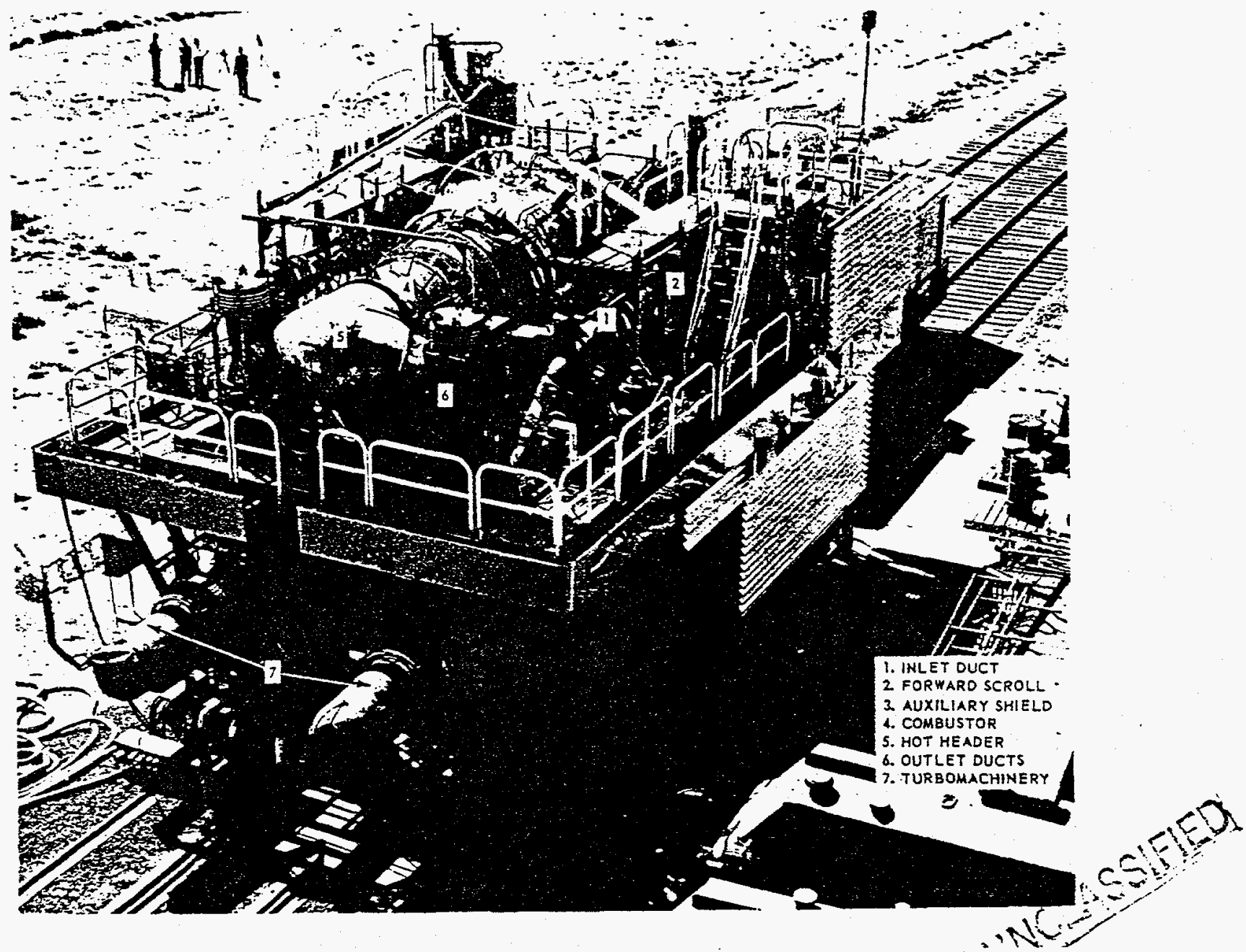

Figure 11. Assembly for HTRE-3. The assembly is on a dolly in position to be towed by the shielded locomotive. Source: APEX901, p. 53 . 
INEL, TAN, HANGAR 629

HAER NO. ID-32-A

Page 50

to speak to a gathering of the American Nuclear society in Dallas, Texas. "When our nuclear-powered airplane is developed... it will be able to fly forever with no fixed address and the limit of its performance will only be up to the endurance of its crew." He promised a test of the airplane in 1963, when a test engine would be mounted on an Air Force B-52 bomber. The engine would have its own new uniquely designed airframe two years later-the "revolutionary NX-2 tail-first plane."

Eventually, he said, nuclegr-powered bombers would fly at three times the speed of sound.

The next day President John F. Rennedy delivered his first message on the defense budget to the United states Congress. His predecessor, President Dwight $D$. Eisenhower, had proposed that either the direct or indirect cycle be eliminated, but did not specify which one. Most ANP interests were expecting Kennedy to announce a choice. The rumor mill had been working for months, various parties predicting which one he would 96 select or, indeed, that he might carry on with both approaches. 96

Senator Henry Dworshak of Idaho, and a member of the JCAE, had to deal with his Idaho constituents as best he could when the rumors reached Idaho and then bounced back to him. As he and the rest of the JCAE prepared to hear from the familiar ANP cast of characters in hearings on March 8, 1961, he explained to an Idaho associate that "there seems to be so much apprehension because of the somewhat indefinite results so far achieved" after fifteen years and $\$ 1$ billion.

However, after the March 8 hearing, Dworshak thought prospects for the ANP looked good. "Representatives of Pratt and Whitney and General Electric," he wrote, "made such an impressive presentation on the progress in developing an ANP power plant before the Joint Committee on Atomic Energy today that probably recommendations will be made to the president to continue research and development on both direct and indirect cycles for at least another year." Democrats on the committee certainly

\section{5 "Designer Eyes Nuclear Plane," Post-Register, March 28,} 1961, Morning Edition, p. 1. NX-2 was the name given to a proposed subsonic aircraft to be compatable with both direct and indirect propulsion systems and capable of test flight. The Air Force contracted with Convair in October 1960 to develop the plane. See Comptroller General, p. 24-25.

96 See samples of mail to Henry Dworshak: Telegram from Robb Brady, Idaho Falls Post Register, January 29, 1961; Letter from (Idaho state Senator) C.A. Bottolisen, March 2, 1961; Dworshak Papers, Box 122-B, File: AEC Idaho Plant. 
INEL, TAN, HANGAR 629

HAER NO. ID-32-A

Page 51

favored continuing both approaches, he said. The Air Force wanted to develop an airframe and test fly it; the AEC ranted to select the cycle that most closely met the Department of Defense requirements. And the JCAE felt that putting an atomic plane into the air before the soviets could do it offered "great psychological appeal." Dworshak thought it likely that a flight schedule might actually be expedited.

But President Rennedy surprised everyone. "We propose to terminate development effort on both approaches on the nuclear power plant, comprising reactor and engine, and on the airframe." he suggested that research continue on the developmegt of high temperature materials and high performance reactors. 9

Kennedy, after campaigning for president partly on the premise that the United States was on the short end of a "missile gap" between it and the soviet Union, had learned quite the opposite after he assumed the presidency. There was no missile gap; in fact, the United states was in a superior stockpile position to that of the Russians. However, Eisenhower's eight years of cutting budgets for conventional defense weapons in lieu of a cheaper arsenal of nuclear weapons for "massive retaliation" had weakened the country's flexibility in defense considerably, Rennedy felt. His Secretary of Defense, Robert S. McNamara, discovered that the country had only eleven combat-ready Army divisions, little reserve capacity, a shortage of ammunition, and low airlift capacity. In order to provide tactical air support for the Army, the Air Force admitted it would have to borrow ordnance from the Navy.

These conditions limited the United States' ability to take the initiative. The world had changed since the 1950s; Rennedy and his advisors no longer viewed the world as one where a military showdown between the two superpowers was the likely outcome of their competition. A Third Forld existed, where the

97 Letter to Bottolfsen from Henry Dworshak, March 7, 1961; dayletter to J. Robb Brady from Henry Dworshak, March 8, 1961; Dworshak Papers, Box 122-B File: Atomic Energy Commission Idaho Plant.

98 Text of John F. Rennedy's "Special Message on Defense Budget to Congress of the United States," March 28, 1961, was widely quoted in newspapers, printed in the Congressional Record, and elsewhere. Part of it was attached to a letter Erom USAF Major General Thomas C. Musgrave, Jr., to Henry Dworshak on March 30, 1961, describing the impact of the decision on contractors and their employees. Dworshak Papers, Box 122-B, File: AEC Miscellaneous. 
INEL, TAN, HANGAR 629

HAER NO. ID-32-A

Page 52

struggle required political and economic initiatives. The nation needed capacity for more limited respgnses than was available merely with a massive atomic arsenal.

One of the consequences of Eisenhower's reliance on atomic retaliation as a defense was that the Air Force had evolved as the most powerful and influential service with the Congress during the 1950s. It, along with employee-heavy contractors flung out in production complexes all over the country, fought for systems that could deliver atomic weapons "massively." General Electric's promotion of atomic airplane research repeatedly emphasized its economical aspects: it would eliminate foreign air bases and their maintenance costs, eliminate tankers (and their supply and escort fleets) for air support, eliminate all the logistic support related to the refueling of chemical bombers. 100

But the time granted the Air Force to prove an atomic airplane had come to an end. The purpose of the president's defense message was to explain why he wanted Congress to raise the Defense Department budget to $\$ 43.7$ billion, the highest it had been since World War II. In the interest of a more flexible defense, he wanted more missile-firing polaris submarines, more Minuteman rockets, and more guerrilla-warfare capability. With these new priorities contributing to a net increase in the budget, he had to reduce the impact somehow. Programs that had not proven themselves took the hits: the Army's unproven NikeZeus anti-missile missile; the Air Force's B-70 bomber, which supposedly would become operational in the late 1960s--by which time United states missile capacity would make it unnecessary; and the atomic airplane, because "nearly fifteen years and about $\$ 1$ billion have been devoted to the attempted development of a nuclear-powered aircraft; but the possibility a militarily useful aircraft in the foreseeable future is still very remote..." The ANP cut would save $\$ 35$ million. 101

The vast ANP community all over the country was stunned.

99 Arthur M. Schlesinger, Jr., A Thousand Days, John F. Kennedy in the White House (Boston: Houghton Mifflin, 1965), p. $300-301,307$.

100 L.F. Harman, General Electric Aircraft Nuclear Propulsion Systems Applications for the National Defense (GE Atomic Products Division, ANP Department, MaY 9, 1958), p. 5, 7.

101"Rennedy Asks $\$ 2$ Billion Defense Insurance Hike," and "APlane Work Halt Asked by JFK in Defense Message," Idaho Daily Statesman, March 29, 1961, p. 1 and p. 6 respectively. 
INEL, TAN, HANGAR 629

HAER NO. ID-32-A

Page 53

Reaction was immediate. GE, whose public relations and lobby machinery had successfully kept its direct cycle program alive for so many years, protested that it could fly in 1963 with "less than one-fifth of one billion dollars" if it could use a $B-52$ airframe and not wait for a Convair prototype. 102

The AEC, as represented by Commissioner Robert Wilson, had told the JCAE on March 8, "Since [1959] we have made excellent technical progress assuring the stated advanced performance objectives of DOD. They lead us to believe that we can provide a flight reactor capable of meeting that performance on a reasonably predictable time schedule." Both cycles, he said, were poised "on the threshold of very significant new reactor experiments."103 The president had now suggested that $\$ 25$ milizion of the ANP funds be directed to the AEC for advanced research in the field $8 \mathrm{f}$ high temperature materials and high performance reactors. 104

Melvin Price of the JCAE said Kennedy's cancellation of the program "is a decision I regret and question. This means indefinite delay for the flight test program." He reiterated a theme present in GE publicity pamphlets for several years: We should not wait for a "perfect" plane because we can not foresee all the possible military uses "until we get an experimental engine in operation. When something has been demonstrated our military people see a great many uses." He blamed the Defense Department and its scientific adyisors for their "on again, off again" approach to the project. 105

A group of Democratic JCAE members made a trip to the white

102David F. Shaw, "General Manager's Report," Aircraft Nuclear Propulsion Department News (Volume 5, No. 13, March 31 , 1961), p. 1. See also "GE Ready to Perform First Experimental Flight in 1963," same issue, p. 1.

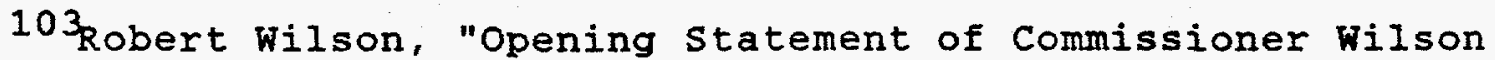
Before the JC on AE on the ANP Program, March 8, 1961," Dworshak Papers, Box 122-B, File: Atomic Energy Commission Idaho Plant.

104 Idaho Daily Statesman, March 29, 1961, p. 6, op cit. Also see York's account in Race to Oblivion describing the consolidation of views by himself, Rennedy's defense-secretary designate Roswell Gilpatrick and science advisor Jerome wiesner during 1960 favoring ANP termination.

105 Congressman Melvin Price, "statement on Cutback in ANP," Press release March 28, 1961; Dworshak Papers, Box 122-B, File: Atomic Energy Commission AEC Press Releases. 
INEL, TAN, HANGAR 629

HAER NO. ID-32-A

Page 54

House to try and change the president's mind, but all appeals were fruitless. 106 Even the disinformative dark warnings about the Soviet Union's imminent--or already achieved--nuclear flight that had circulated in recent years had lost their power to float the ANP. "A nuclear-powered bomber is being flight tested in the Soviet Union," Aviation Weekly had said in 1958, "Completed about six months ago, this aircraft has been observed both in flight and on the ground by a wide variety of foreign observers from communist and non-communist countries." 187

A GE booklet published in 1958, when memories of sputnik were still fresh, had said, "The scoreboard indicates: USSR first in space satellite program, USSR planning to launch first nuclear plane...WE cannot wage technological war defensively [or] afford

"too little, too late." The atomic airplane, suggested GE, would simplify so many useful military functions--global surveillance, world-wide logistic support, intelligence, inspection, reconnaissance, global show of force, aerial retaliation, aerial attack, and aerial occupation--that it was inconceivable that the United states should lose the chance to score first. But by 1961 it seemed clear to the Rennedy administration that these functions could best be accomplished by other means. 108

Business groups in Idaho Falls wired Dworshak, "Your immediate attention and influence to affect a reversal of President Kennedy's proposal to scuttle the A-plane program is requested. This proposal if successful would be a serious blow to the economy of southeastern Idaho." IO Likewise several Idaho state legislators: "If carried out adverse impact on Idaho economy will be severe... [affecting] hundreds of jobs." While national defense was expanding elsewhere, they complained,

106 Letter to Idaho state senator A.W. Naegle from Henry Dworshak, March 31, 1961; Dworshak Papers, Box 122-B, File: Atomic Energy Commission Idaho Plant.

107" Soviets Flight Testing Nuclear Bomber," Aviation Week (December 1, 1958), P. 28 .

108.F. Harmon, General Electric Aircraft Nuclear Propulsion Systems Applications For The National Defense (Cincinnati: GE Atomic Products Division, ANPD, May 9, 1958), p. 6, 12 .

109 Telegram to Henry Dworshak from Idaho Falls Clearing House Association, Bank of Commerce, Bank of Idaho, First Security Bank of Idaho, First National Bank, March 30, 1961; Dworshak Papers, Box 122-B, File: Atomic Energy Commission Idaho Plant. 
INEL, TAN, HANGAR 629

HAER NO. ID-32-A

Page 55

Idaho's participation was being reduced. ${ }^{11} 0_{\text {Idaho Governor }}$ Robert smylie warned President Rennedy that the loss of ANP's 500 jobs would be a blow to Idaho of "disastrous proportions" and asked for some replacement research that would keep the jobs in Idaho. 110ther research projects appeared in due course at the NRTS (not specifically as ANP replacements), but a "disaster" did not occur as predicted. 112

At Test Area North, the Flaho Falls Post Register reported employees as "thunderstruck. "11 GE had assembled a productive enthusiastic team, and it possessed a certain esprit d'corps.114 Now it would have to disperse. The cancellation eliminated 6,000 jobs in seven states. GE, with the majority of its force in ohio, dismissed 1,450, transferred 790, and managed to keep 400. It shifted some of its Idaho employees to other work at the site, but by september 1961, only 25\% of them remained.115ut all of Test Area North's empire of buildings remained, including the never-used hangar and its satelites.

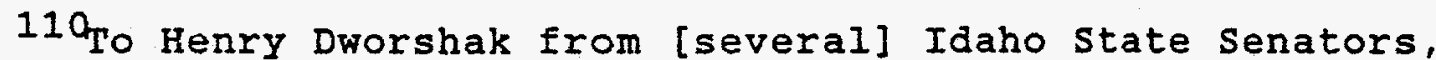
March 31, 1961; Dworshak Papers, Box 122-B, File: Atomic Energy Commission Idaho Plant.

111 To President John F. Rennedy from Governor Robert E. Smylie, March 29, 1961; Dworshak Papers, Box 122-B, File: Atomic Energy Commission Idaho Plant.

${ }^{112}$ In April 1961, the ABC's Idaho Operations office announced that a new reactor experiment would be located at the NRTS. See Dworshak Papers, Box 122 B, File: AEC Idaho Plant.

113."Kennedy Wants A-Plane Junked, New GE Effort," Post Register, March 28, 1961 Home Edition, p. 1.

$114 \mathrm{~J}$ ohn James, Lockheed engineer, interview with Susan $M$. Stacy, May 12, 1994, at Idaho Falls.

115. ANP Termination Leaves Vast Facilities, Big Technical Legacy," Nucleonics (August 1961), p. 26-27. See also letter from John W. Morfitt, Manager, ANPD, to Henry Dworshak, September 26, 1961; both in Dworshak Papers, Box 122 B, File: AEC Idaho Plant. GE saved the jobs of 70 of its top engineers by offering their expertise in the decontamination and removal of the reactor known as SL-1 elsewhere at NRTS. SL-1 was a prototype of a small U.S. Army portable reactor intended for use at remote locations. An accidental steam explosion on January 3, 1961 had destroyed the reactor and killed three men. Nucleonics felt that $G E$ had won the contract precisely because its top men were available. 
INEL, TAN, HANGAR 629

HAER NO. ID-32-A

Page 56

\section{PART TEN}

\section{AFTER ANP: ONE HANGAR FOR RENT}

The ANP facilities "aren't being used for anything, are they?" asked a JCAE pember of AEC Commissioner Glenn seaborg at a closed 1962 hearing. 116 The TAN hangar was definitely available-and continued to be through the 1960s. Its vast spaces had been used for incidental storage only. But a plan for its use was taking shape.

Some of the other facilities in Test Area North had continued in use after ANP closed down. With its truncated staff, GE took overflow work from some of the other contractors on the site and did hot cell work for them. The Test Shield Facility was popular, too. Now that the unique "swimming pool" was available to the rest of the site, it was in demand 24 hours a day all week long. GE itself used its labs and hot cells after it won a contract with the Army to decontaminate and dispose of the remains of the stationary low-Power Reactor (SL-1), a reactor that had been destroyed in an accidental steam explosion at the NRTS in January 1961.117

\section{LCRE: Lithium Cooled Reactor Experiment}

Pratt and Whitney ( $P \& W)$, the company pursuing the indirect approach to nuclear flight, had been working on promising new frontiers in reactor development just as ANP was canceled. AEC desired to continue this research, not for atomic flight, but looking outward to space. Space satellites would need a source of electricity to carry out their missions for deep space probes, surveillance, communications, television broadcasting, and electric propulsion. Perhaps a nuclear reactor could power a generator. BY 1958 P \& W had plans for a reactor that could produce high heat and yet remain small and light-weight. It would use lithium, a liquid metal and an excellent exchanger of heat, as the coolant. Lithium's other virtue was that it would not rob. the reactor of neutrons and slow down the reaction.

On the other hand, the liquid had to be contained in the circulation piping, and lithium was not compatible with nickel

116 To Henry Dworshak from James T. Ramey, Exec. Dir. for JCAE, March 1, 1962; Dworshak Papers, Box 84, File: AEC Idaho Plant.

117 To Henry Dworshak from John $W$. Morfitt, GE Idaho Test station, September 26, 1961; Dworshak Papers, Box 122 B, File: AEC Idaho Plant. 
INEL, TAN, HANGAR 629

HAER NO. ID-32-A

Page 57

and steel alloys, the materials of which such piping was made. $P$ \& W found that the metal columbium was compatible with lithium, but that it oxidized "catastrophically" in the presence of oxygen. If used, it would have to be kept in an oxygen-free environment. Scientists were working on a reactor design in which the coolant loops were surrounded by nitrogen and argon gases. They needed to prove the lithium/columbium principle as a feasibly safe design, and also test it with a complete meltdown and a power excursion of the core.

At ANP cancellation, $P$ \& $W$ scientists were thinking of their reactor powering a bomber, with a design life of several hundred hours. In redirecting the work, the AEC now specified a reactor with a 10,000 hour lifetime-more useful in space. AEC assigned $P$ \& $W$ to continue its experiments at the TAN hangar in a project it called Lithium Cooled Reactor Experiment (LCRE).

The LCRE was to be part of a program named SNAP, or Systems for Nuclear Auxiliary Power. It had begun in the 1950 s as a joint effort between the AEC and the Air Force. Now it was a joint project of the AEC and the National Aeronautics and space Agency (NASA). This experiment would be part of SNAP-50, the latest in a series of reactors designed for progressively higher power ratings. SNAP-50 rated at 1,000 kilowatts. Its specific objective was to provide efectric rocket propulsion of space vehicles by the late 1960s. 118

$P$ \& would have preferred to conduct the project in Connecticut, but the AEC thought that it would be safer and done faster at NRTS. $11 \mathrm{P}_{\mathrm{P}} \& \mathrm{~W}$ examined the hangar site and prepared design criteria for remodeling the hangar to suit. They would use the north half of the hangar, the side closest to the control and Equipment building. This would facilitate remote disassembly after the experiment. The hangar building offered heating and ventilation systems, alarm systems, and air sampling and radiation monitoring stations. The LCRE would be constructed at grade on the concrete floor of the hangar, although some excavation through the concrete would be required to build foundations for the test cell, the hot cell walls, reactor experiment equipment supports, and cryogenic trap cells (to hold

118 John F. Hogerton, The Atomic Energy Deskbook (New York: Reinhold Publishing Corporation, 1963), p. 511.

119 See "Pratt and Whitney gets Major Nuclear-Space Assignment: SNAP-50 Reactor Systems," Nucleonics Week (Volume 3 , Number 13, March 29, 1962), p. 1; and Frank D. Haines, "SNAP50/SPUR Reactor Development," unpublished paper, INEL Technical Library, Idaho Falls, no date. 
INEL, TAN, HANGAR 629

HAER 10. ID $32-A$

Page 58

gases at very low temperatures). The coupling station in the middle of the hangar floor could be used as the argon Room, where they could house the equipment needed to maintain an argon atmosphere in the test cell and to maintain an airlock during the fuel removal. In effect, LCRE would be a group of buildings sheltered under the hangar roof. 120

Besides the hangar, the experiment would require use of the Control and Equipment building (TAN 630), parts of the Assembly and Maintenance building (TAN 607), the Health and Safety building (TAN 606), and the service building (TAF 603). Each could be modified to serve the new experiment. And it would need a steel stack 150 feet high and 11 feet in diameter outside the northeast wall of the hangar.

After Congress authorized the funds in the fall of 1962, $P$ \& $W$ prepared to move its work from Connecticut to Idaho. It designed a console for the control rooms, organized several training programs, prepared operating manuals, prepared general operating procedures, forecast its manpower needs, and recruited personnel. In the hangar, contractors began a fer of the modifications to the building. They removed about one-third of the hangar's concrete floor, pierced the east and north walls with rectangular holes for ducts, and prepared foundations for the cryogenic tanks north of the building.

suddenly all activity stopped. AEC and NASA reoriented SNAP50 in 1963. The holes in the hangar walls were patched; the floor was leveled, filled in and restored; and the grade beams and piers for the would-be cryogenic tank were left as they were.

LOFT: Loss-of-Fluid Tests

"Potentially Available Facilities," said the brochure. 122 The Eastern Idaho Nuclear Industrial Council had surveyed the

12 Design Criteria for Lithium-CRE at NRTS, CNLM-4043 (Middleton, Connecticut: Pratt and Whitney Aircraft, Division of United Aircraft Corporation, CANEL, April 27, 1962), p. 10 ff. Burns and Roe, Inc., Engineers and Contractors, of New York City produced the architectural and other drawings for Pratt and Whitney.

\section{Reactor Operations Final Report, LCRE, PRAC-408} (Middleton, Connecticut: AEC Research and Development Department, Pratt and Whitney Aircraft, January 30,1964$),$ p. 7, 16 .

$122 \mathrm{Dx}$. E. Fast, compiler, Potentially Available Facilities at the National Reactor Testing Station (Idaho Falls: Eastern Idaho Nuclear Industrial Council, February 1970), p. 14. 
INEL, TAN, HANGAR 629

HAER NO. ID-32-A

Page 59

empty buildings at the site. Southeast Idaho had grown to rely on NRTS as a major part of its economy. The Council was a private group interested in marketing the opportunities presented by 20 vacant buildings with over 223,000 square feet of floor space-mostly at Test Area North.

It was 1970 and the government's nuclear reactor research program had begun to diminish. The cost of research had been rising--along with the cost of licensing and building new civilian nuclear power plants. A new director of AEC's Reactor Research and Development division, Milton Shaw, felt that sodiumcooled reactors offered more promise than any other type, so he canceled several other projects previously scheduled at NRTS and narrowed the focus of reactor research. 123

Further, the environmental movement questioned how well the government was managing the disposition of nuclear wastes. The public began questioning the safety of nuclear power plants. In addition, the government was using its resources to conduct the Vietnam War and to finance space exploration, both tough competitors for reactor research.

At least one part of the hangar was alive with movement again, but only temporarily. Its large open expanse had attracted storage crates for ten years lold Navy equipment, heat exchangers from the decommissioned Hallam Nuclear Power facility in Nebraska, and other slightiy contaminated material) but now a new project going up east of the Control and Equipment building made some modest use of the old hangar.124 The contractor (Howard $s$. Wright and Associates) had set up a fabrication shop on part of the hangar floor.

The new project was part of the ABC's Nuclear safety Program. One of the most hazardous accidents that could occur at a commercial nuclear power plant (or any reactor) was thought to be a sudden loss of the coolant--a "loss-of-fluid"--and a subsequent release of fission products from the fuel. Among the causes of such an accident might be the failure of some component of the cooling system. The safe operation of commercial nuclear power plants was an important concern. The concept for the original Loss-of-Fluid Test (LOFT) was the question: "What is the life of all the components of a commercial reactor and how good

$123 \mathrm{Jack} M$. Holl, Roger M. Anders, and Alice Buck, United States Nuclear Power Policy, 1954-1984: A Summary History

(Washington, D.C.: U.S. Department of Energy, Office of Executive Secretariat, History Division, DOE/MA-0152, 1986), p. 12 .

124 John James, May 12, 1994. 
INEL, TAN, HANGAR 629

HAER NO. ID-32-A

Page 60

are they?" Components included the pumps, valves, pipes, conversions to power, and all the other gadgetry involved in a reactor.

The originators of the research wished to test commercially available components, not the specialized and super-precise components hitherto used in reactor research, and validate their reliability. They needed a facility in which they could subject these components to a loss-of-coolant accident, a Maximum Credible Accident, or MCA. What would happen in such an accident?

The experiment designers (Kaiser Engineers) envisioned using the old ANP hangar for the test. It was remote, a definite requirement for a hazardous test. It featured shielded roadways and tunnels; someone had already designed these with emergency escapes in mind. They could build the reactor and its containment vessel over the part of the hangar floor originally intended for the elevator--which had never been installed.

The MCA was considered to result from a double-ended shearing of the coolant exit pipe--a "large break." The experiment would stage this event. Temperatures would rise so high that the cooling water escaping from the broken pipe would instantaneously flash to steam, releasing violent explosive pressure. At the same time, the uranium fuel would continue to react, releasing dangerous fission products, and melting "down" through the floor of the reactor vessel. Beneath the reactor a "titanium potty" would receive the uranium, break it up, and drop it into a tank below, quenching the reaction.

The designers soon realized that it would not be practical to build a containment vessel within the hangar. It would be easier to excavate subsurface tanks and concrete shields on the east side of the Control and Equipment building. The experimenters could still employ the hangar's four rails and double-wide flat cars by installing a new spur leading to the LOFT building. They could mount the reactor vessel, heat exchanger, pressurizer, and primary pumps and roll them inside the containment vessel.

After the loss-of-fluid event would come the various checks. Did the containment vessel survive? What components survived the thrust? Was there a meltdown? Could they clean up after the accident? How?

In 1962 the AEC approved an experiment, and in June of 1963 
INBL, TAN, HANGAR 629

HAER NO. ID-32-A

Page 61

Congress authorized $\$ 19.4$ million for it. 125 But the original idea for the experiment was reassessed and redirected--more than once. Between 1963 and 1975, the nuclear industry decided that a test of safeguards intended to prevent a loss-of-coolant accident would be more valuable than a test of components, for which other testing techniques had arisen. Thus the objective of the test was revised, which required considerable time to modify the designs. BY 1968, all construction had stopped in order to await redesign instructions. Frequent stop-starts caused by design lags, contractor problems, changes in management, the need for more funds from Congress, a labor strike, and other problems, occurred until the summer of 1976, when the facjijty was at last ready to have the core loaded into the reactor. 126

The new program was to test concepts of Emergency Core Cooling, in which back-up systems would activate upon a loss-offluid event. A series of tests would shut off the coolant and let the temperatures rise to ever increasing levels before the Emergency Core Cooling was actuated. By the time the experiments began, computer programs had been generated to predict what would happen to the reactor. Another useful purpose of the tests would be to validate these computer programs and their results--or not.

The old hanger did perform some service to the LOFT program. An auxiliary power supply--batteries, motor-generator sets, diesel generators, and switching gear--were set up in the east side of the hangar. Piping was arranged for diesel fuel supply and fire protection. The hangar also sheltered office trailers and an instrument shop. Between 1978 and 1980 the hangar basement was modified for additional storage, a lunchroom, restrooms, and showers. The Control and Equipment building housed the control consoles for the reactor. The ANP cooling tower was removed.127

The 55-megawatt reactor (about one-fiftieth the scale of typical commercial reactors) was placed in a new domed containment building with the help of the new four-rail track. The building's substantial 200-ton doors were ready to withstand

125 Historical Brief of the LOFT Project at the Idaho National Engineering Laboratory (Idaho Falls: Aerojet Nuclear Company, December 1975), p. 1. Hereafter cited as Historical Brief.

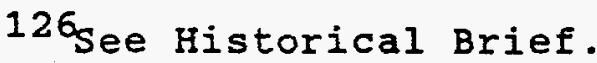

127 Julie Braun, Draft Preliminary Report, Aircraft Nuclear Propulsion Program: TAN Hangar 629 (Idaho Falls: INEL, Idaho Field office, June 30,1993$),$ p. 5. Also, personal communication with Eric Yde and Bud White, May 10, 1994. 
INEL, TAN, HANGAR 629

HAER YO. ID-32-A

Page 62

the force arising from a flash to steam. In December 1978 scientists opened a valve to simulate a "large break" in the cooling pipe, and the first nuclear LOFT experiment began. It was over in thirty minutes. They learned that water flowed into the reactor vessel faster than it was expelled in the crucial first seconds after the "break," which kept the core cooler than they had expected.

Before a second test could be arranged the following May, an accident at a commercial nuclear power plant at Three Mile Island (TMI) in Pennsylvania caused a partial meltdown of the reactor core. LOFT scientists altered their work schedule and used their models (Semiscale) and computer programs to help determine how a potentially dangerous hydrogen bubble inside the TMI reactor could be dissipated. When the crisis was over, LoFT returned to its own test program, but as a result of TMI accelerated the study of "small breaks." The TMI experience had demonstrated that these, combined with the inappropriate intervention of human operators, potentially could be as dangerous as the larger ones.

Financing for LOFT experiments ran out in 1982 after 30 tests. An international consortium arranged to fund several more tests, including the last one in 1985, when scientists tried to simulate the Three Mile Island accident and melt the core. The core rose to 4,000 degrees $F$. , but did not melt. After 30 minutes, the safety system flooded the core and cooled it off. That event was analyzed, and the LOFT program officially ended in 1986 .

This time, the hangar building would not languish vacant for long. The United states Army had secret plans for the building.

\section{PART ELEVEN}

\section{THE HANGAR TODAY: PROJECT X}

In the fall of 1983 the Army initiated a classified project using depleted uranium to manufacture a special armor for its M1A1 Abrams tanks. The Army chose the hangar as an ideal location because it was in an isolated location and because its expansive clear space was roomy enough to hide an 82,000 square-foot

128 Bob Passaro, "TAN has Colorful, Secretive Past, to be mothballed by 2000," Post Register, May 15, 1994, p. H-12. The damaged core and tons of other contaminated waste from TMI was sent to the site for analysis and study. 
INEL, TAN, HANGAR 629

HAER NO. ID-32-A

Page 63

building three stories high from the eyes of satellites passing overhead. The fabrication techniques and production formulae remain classified. Because of the secrecy associated with the project, site workers and the media called it Project $x$. The plant is officially named specific Manufacturing Capabilities (SMC). The process does not include a nuclear reactor or fissionable products.

The Army initially contracted Exson Nuclear Idaho Company to operate the plant. The hangar was modified for the new program beginning in July 1983. The prototype armor shell was produced in 1985. From 1986-1991 Rockwel1-INEL managed the plant. By 1988 the SMC, employing about 500 people, was shipping armor to Lima, Ohio, where it was fitted onto the tanks. Up to 1994, an estimated 2,500 tanks have been equipped with the armor. The tanks received their first combat experience in the 1991 Persian Gulf War, where they weathered direct hits from enemy "armorpiercing" shells.

The Army announced publicly what it was doing in 1990, the first time SMC employees knew the purpose of what they were making. When Rockwell's contract ended in 1991, the Army decided to continue production at the plant for several more years in order to retrofit an additional 800 of its older tanks. It contracted Babcock and Wilcox, Idaho, to manage this work. As of october 1, 1994, Lockheed Idaho Technologies Company is the most recent manager, employing over 350 employees and producing about 60 packages per month, a schedule that will kefg the hangar occupied until about the turn of the century.

Although the public now knows what product is manufactured in the hangar, it remains a guarded environment. Neither the author or the photographer who took photos of the interior of the hangar building for this report were permitted to enter or photograph the SMC building directly. The photographer was, however, allowed on the roof of the building and various catwalks in order to record certain features of the hangar interior.

Establishing the manufacturing "capabilities" involved the construction of accessory buildings and storage areas around the hangar building as well as a few modifications in the hangar itself. A Babcock and Wilcox representative identified the SMC modifications to the building and its immediate environs as follows :

* removed portions of the hangar's concrete floor for

12San Egan, "Armor Shield for Tanks Made in Test Area North Hangar," Post Register, May 15, 1994, p. H-12. 


$$
\text { 4to }
$$




INEL, TAN, HANGAR 629

HAER NO. ID-32-A

Page 65

installation of under-floor utilities.

* constructed a boiler building (TAN 675) directly abutting the hangar on the north side. This building contains 10,400 square feet and is directly accessible through passages cut through the hangar doors.

* constructed the three-story Manufacturing Building inside the hangar. It occupies about $80 \%$ of the interior floor space.

* welded shut the hangar doors.

* installed intake and exhaust louvers in the doors at both (hangar door) ends of the hangar.

* constructed the Truck Receiving building (TAN 677) directly abutting the south end of the hangar. Passageway to hangar was cut through the hangar doors.

* constructed the Waste Handling structure directly abutting the west side of the hangar.

* removed the LOFT instrument ${ }_{3}$ hop and auxiliary power supply equipment from the hangar. $13 \delta^{\circ}$

In adition to these production-related requirements in fitting the building for manufacturing, the current occupant--and various past occupants--have tried to fix the hangar's leaky roof. All previous attempts failed to make a lasting improvement. The current effort--and the one that led to the requirement for this report--will result in covering the roof with a metal shell and changing the appearance of the hangar.

The Flight Engine Test facility, alias SMC, is a reinforced concrete structure with ten arched ribs of reinforced concrete supporting a barrel shell roof. It covers a floor area of 320 feet by 257 feet. Exterior dimensions of the building (measured from the rear and excluding the front door pocket projections) are 330 feet by 255 feet and 2 inches. On the first floor a passage gives entry to the Control and Equipment building on the east side. A basement level contains a series of tunnels, some of them connecting to the Control and Equipment building. The exterior side walls are reinforced concrete 1.25 feet thick. The shell of the reinforced concrete roof is approximately six inches thick. The exterior curve of the arch ribs rise 104.5 feet above the floor at the crown.

$$
130_{\text {See }} \text { Braun, p. } 6 \text {. }
$$


INEL, TAN, HANGAR 629

HAER NO. ID-32-A

Page 66

At the front end of the building (the south exposure) is a set of structural steel metal doors, motor-operated (previous to being welded shut), and consisting of eight leaves, four on each side of the center. (See Photo No. 6.) These slide on wheels along trenches into door pockets that are 12 feet thick and extend a little more than 42.5 feet beyond the concrete side walls of the hangar. They open the hangar to a width of 320 feet. The entire door assemblage makes up the rectangular front wall of the hangar, all made of structural steel, with dimensions of 405.5 feet wide and 70 feet high. The lower fifteen feet of the doors are clad with a flat skin of heavy sheet steel (rather than corrugated metal like the upper part of the doors), offering extra protection from truck collisions and wear and tear at the ground level.

The first arch rib is visible above the door and rises another 34 feet to the crown. The ribs extend down to join their concrete foundations, which project beyond the edge of the door pockets. The foundations extend beneath grade to bedrock. Because bedrock is not equidistant from grade under all portions of the building, each foundation is of a unique depth below grade. Metal siding covers the section of wall between the door fascia and the arch. The fascia above the sliding doors is about 19 feet wide. It does not extend the entire width of the building, making a gap for a special door.

The special door apparatus is just below the crown of the arch and above the center of the main door. It was intended to permit the passage of an aircraft tail assembly, or empennage. This door is also motorized, the lower part rising into the pocket above it. The door allows about 20 feet extra for the empennage.

Abutting the hangar doors is a one-story flat-roofed rectangular (truck receiving) building. Rectangular patches in the hangar door testify to the holes once made to accommodate conduit or ducting for the abandoned LCRE. Near the truck receiving building the leaf has been pierced for SMC intake and exhaust louvers. A human-scale door has been cut into the western-most door leaf.

The east and west sides of the original hangar were identical except for the Control and Equipment building on the east side. The compacted earth shielding for that building almost reaches to the edge of the hangar roof, hiding most of the concrete arch foundations from view. Either side gives a view of the roof.

During construction, the concrete for the roof was poured in sections. Then hot tar and felt material were placed on top of 
INEL, TAN, HANGAR 629

HAER NO. ID-32-A

Page 67

it. When the wind blows across the roof, it creates a strong negative force on the lee side. This force pulls the protective material off the roof, and water can enter between the poured sections. The end bays tend to suffer the most damage. In the early 1980s, an attempt was made to apply a new product--a rubber roofing membrane. By that time, the concrete was exposed to the elements and had been subject to freezing and thawing. The new membrane did not work. Photos No. 7, 8, 9, and 10 show this rubber membrane.

In 1987 Morrison-Knudsen Company was contracted to try another method of fixing the end bays--covering the roof with a material called Hypalon. The wind blew it off before the project was done. Finally, INEL hired an architect for advice on how the roof could be repaired at a reasonable cost considering the anticipated life of the building. The architect suggested six alternatives. Babcock and Wilcox evaluated them and concluded that the best approach was to over-build the roof with a new metal shell. Commercial siding and Maintenance Company of Ohio was awarded the bid for the work, which began in 1994. Babcock and Wilcox engineers are convinced that the steel bolts affixing the metal to the building will withstand the wind. The shell will cover the arch ribs and concrete roof slabs, although these wiIl remain intact underneath. The project was estimated to be complete in December 1994.

If the bays (between the arch ribs) are counted from the front to the rear of the hangar, bays number two and eight contain construction joints. Bays four and six contain expansion joints. The expansion joints in the roof were matched to similar joints in the concrete side walls. The arches rest on their abutments to the foundation at a height of about 26 feet above grade.

The (relatively small) Waste Handing structure abutting the west side wall is approximately the width of one bay between the arch ribs--or about 26 feet wide. Unseen are openings for pipe penetrations between the structure and the hangar.

The north exposure of the hangar is similar to the south, but lacks a special door for an aircraft tail and the flat metal skin on the lower portion. Also, the door is only six leaves wide, three on each side. These slide into pockets at the side of the building, with the outer edge of these pockets nearly flush with the side walls of the hangar. The doors open to only 240 feet. Abutting the doors is a one-story rectangular (boiler) building that extends nearly the entire width of the doors. Because there is no empennage door, the fascia above the doors continues without a break above the entire door assembly. 
INEL, TAN, HANGAR 629

HAER NO. ID-32-A

Page 68

Views inside the hangar are considerably obstructed by the presence of the three-story SMC building. However, the photographer was permitted access to the SMC roof and catwalks and took several photos from that vantage. Light fixtures and other service conduits are attached to the bare concrete ceiling. The lamps can be lowered to ground level when the bulbs burn out. Photo 23 shows moisture on the SMC roof from leaks in the hangar roof above. At the north and south ends of the hangar, a row of triangular braces supports the metal wall above the hangar doors.

The shadow shield protecting the entrance to the Control and Equipment building corridor is 16 feet high, 38 feet long, 4 feet thick, and made of conventional reinforced concrete. A few yards to the north of it is the viewing window. This was heavily shielded and constructed of alternating panes of glass and an oil of the same refractory index as the glass. A corridor from the Control and Equipment building permits access to the window.

The coupling station, which is now enveloped by the SMC building, was constructed of 26 separate blocks of high density concrete. As assembled, they made a table-like enclosure about five feet high with walls and roof at least three feet thick. Only one side of the "table," the side facing the front hangar doors and the trackage, was open. The opening was for the utility connections between the aircraft and the control room and provided personnel access to the service area and tunnels below. Beyond the utility openings, where conduits angled toward the basement, strategically placed lead blocks were positioned to prevent radiation streaming into the coupling station structure. These lead blocks, while not visible today, are still in place. The top surface of the station measures 30 feet wide by 22.33 feet, the 30 foot dimension being parallel to the doors. Personel access was through a steel hatch door in the top of the coupling station. The door opened horizontally, sliding along a set of rails.

The four-rail trackage served the general Test Area North complex and remains in place. The hangar floor and track leading to the coupling station slopes up about one foot between the entrance to the hangar and to where it leveled off just in front of the coupling station. The track has been covered with concrete inside the hangar and with asphalt just outside the hangar.

In addition to the rectangular buildings stuck like magnets to the hangar, other SMC buildings, storage yards, and utility areas now grace the hangar neighborhood. 
INEL, TAN, HANGAR 629

HAER NO. ID-32-A

Page 69

\section{PART TWELVE}

\section{NOTES ON CONTEXT AND SIGNIFICANCE}

No significant event connected with atomic flight or any other scientific discovery ever took place inside or because of the TAN 629 Flight Engine Test hangar. However, its location on an Idaho desert amidst a sea of sometimes inelegant industrial buildings has lent the building great utility as a symbolic representation for other themes. Fortune magazine, for example, called the bujifing a "monumental relic of abandoned technology."13i

The hangar can carry even more weighty thematic baggage in American history--if it is allowed to symbolize the canceled Aircraft Nuclear Propulsion program. The possibilities are not Iimited to the following six, but these give ample evidence that the ANP program was part of many important historical contexts.

The Cold War, the Arms Race, and Atomic Energy

The Cold War between the United states and the soviet Union evolved as one aftermath of World War II. Hewlett and Duncan, in their history of the Atomic Energy Commission, Atomic Shield. document how post-war tensions affected the commission. Hoping at first that a program of reactor research would lead to peaceful and productive uses of atomic power, the AEC was forced to shift its resources to military research aimed at weapons development. As the soviets demonstrated their command of nuclear science and nuclear bombs, American fears grew. Because the United states had dropped two bombs upon enemy cities, it was not hard to imagine that the Soviet Union could--and would--do the same.

The AEC had to acknowledge the obvious imperative that weapons development remain one step--or more--ahead of the enemy at all times. Research was essential, and nuclear science was a major frontier. The AEC undertook partnerships with each of the military services to explore many atomic applications. Perhaps the most successful was the U.S. NavY's atomic-powered submarine, a program that progressed beyond research and prototype development into production. Another was the development of the hydrogen (nuclear fusion) bomb.

But there were other projects as well. The army hoped to use nuclear fission for a mobile electric generator suitable for isolated or remote areas. The Air Force and Navy researched nuclear-powered missiles, ramjets, and propeller jets. These and

${ }^{131}$ Gene Bylinski, "Monumental Relics of Abandoned Technology," Eortune (January 28, 1980), p. 90. 
INEL, TAN, HANGAR 629

HAER NO. ID-32-A

Page 70

other projects--not just the nuclear airplane--were canceled when non-nuclear technologies advanced to meet the pertinent military objective more reliably, more safely, and more inexpensively than the nuclear alternative.

The post-sputnik period of the arms race bundled the interests of the military, industrial contractors, and research scientists in ever-intensifying and complex relationships. President Dwight Eisenhower observed these in his last years as president. They alarmed him sufficiently to warn the American public about the "acquisition of unwarranted influence, whether sought or unsought, by the military-industrial complex." He continued, "We must be alert to the...danger that public policy could itşlf become the captive of a scientific-technological elite."132

In his book Race to oblivion, Herbert York, a participant in the arms race, discussed the ANP program and how "hard-sell technologists and their sycophants" manipulated public fears. implicated itself in publishing false information about soviet progress in the "race" for an atomic airplane, and then offered "a thousand and one technical delights" for solving the problem. Whether one accepts York's characterization or not, the political side of ANP's history provides a potent case study of the behavior of both the "military-industrial" and the "scientifictechnological" elites and their influence on public policy at the highest levels of government during the 1950 s.

\section{Air Force}

With the cold War as a backdrop, the ANP program figures as part of the flowering of the Air Force as the most influential and powerful of the military services during the 1950s. Its alliance with congressmen of the Joint Committee on Atomic Energy and executives of the aircraft industry resulted in the expenditure of about $\$ 1$ billion on a small empire with locations studded all over the United states. The effort coincided with a view by President Eisenhower and his cabinet that massive nuclear force would be the best deterrent to the enemy at far less cost than maintaining massive conventional sea and ground forces.

Nevertheless, other interests at the national level constantly challenged Air Force influence. Within the Department of Defense, the other services fought for scarce resources. science advisors to the president and to the secretary of Defense 9.

132 From Eisenhower's Farewell Address, as quoted by York, p.

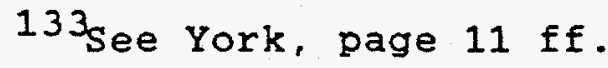


INEL, TAN, HANGAR 629

HAER NO. ID-32-A

Page 71

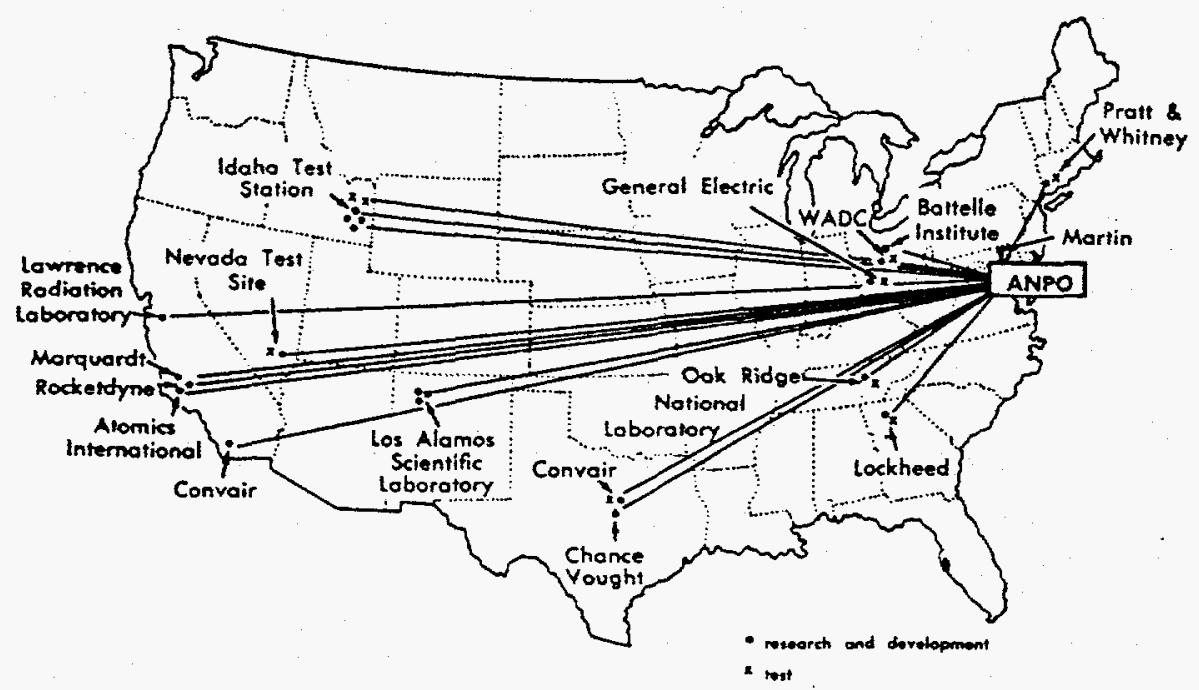

Figure 13. These facilities were involved in various ways in the Aircraft Nuclear Propulsion Program by the time President John F. Rennedy canceled it in March 1961. Source: Gantz, Nuclear Flight, p. 18 . 
INEL, TAN, HANGAR 629

HAER NO. ID-32-A

Page 72

raised enough questions about the progress of the program to "redirect" it numerous times. The election of John F. Rennedy brought new thinking to the needs of national defense and a consequent readjustment in the relative importance and influence of the Air Eorce.

\section{Big Science}

Closely related to the ANP's fortunes as a pawn in Washington's political in-fighting, the ANP represents an example of "big science," that unique collaboration between the federal government, universities, and contractors to engage in largeproject research far beyond the capability of private industry.

The era of modern physics began just before the turn of the century after Marie Curie realized that radium lost weight as it emitted distinct types of radiation. Joseph John Thompson proved in 1897 that the emissions were not "rays" but electrons, particles of matter carrying an electric charge. For the next forty years, both theoretical and experimental physicists made one breakthrough in knowledge after another. Finally, in 1939. scientists conceived of an explosion of "stupendous power," as
C.P. Snow put it, and the era of "pure science" was finished.134 The era when physicists had to scrape together hundreds or thousands of dollars for an experiment gave way to the federal financing of nearly unlimited amounts. The government's interest in weapons and related applications shifted the focus of research from the "realm of science" to the "realm of engineering."135

Although ANP contractors certainly employed physicists in reactor research, they employed far more engineers in the overall problem of a nuclear airplane. The basic design of direct and indirect cycles, the divided shield concept, the design of support and ancillary systems, the remote management of the power plants, and the design of the facilities in which the experiments could take place: these were engineering problems. The Flight Engine Test hangar, with its special adaptations for the nuclear activities planned in the building, is a monument to Big science and its impact in the "realm of engineering."136

Idaho History

The National Reactor Testing Station, renamed the Idaho

$134 \mathrm{C} . \mathrm{P}$. Snow, The Physicists (Boston: Little, Brown, and Co., 1981), p. 100 .

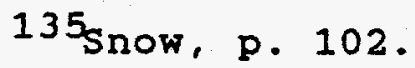

$136_{\text {Snow }}$ used this phrase to describe the U.S. government program to develop an atomic bomb during world War II, p. 106. 
INEL, TAN, HANGAR 629

HAER NO. ID-32-A

Page 73

National Engineering Laboratory in 1974, became of immense significance to the economy of Idaho, particularly its southeast region. By 1959, the year the hangar was completed, the local manager of the site estimated the value of the total physical plant at $\$ 200$ million, with another $\$ 20$ million under construction that year. ${ }^{13}$ Over 4,500 people worked at the site, all but 350 (who worked directly for the Atomic Energy Commission) employed by contractors with a combined payroll of $\$ 30$ million. During most of the 1950 s an additional average of 900 people were employed each year in construction of the reactor experiments. The permanent work force included 600 engineers ${ }_{138} 00$ physicists or chemists, and 300 others with college degrees. 138

In 1949 the AEC projected that the site would see ten reactor experiments by 1964. By the beginning of 1959, the actual figure had climbed to $33_{1} 13$ were still operating, and seven more were under construction. 139 ithin a few short years after 1949 the nuclear reactor industry at the site was the state's largest employer (excepting the state of Idaho itself) and retains that ranking in 1994 with an employee force of about 10,000 people. 140

Naturally, the "primary" jobs at the site supported a large population of "secondary" service sector employees in the towns surrounding the site. It is no mystery that senator Henry Dworshak readily understood the importance of the site--and the ANP--when he observed in 1956 that "there is sentiment in my state for me to sit on the Joint Committee on Atomic Energy."141

The "boom" at the site during the 1950 s was attributable both to military and civilian reactor projects, of which the ANP project was a significant part. Between the AEC and the Air Force, the government poured over $\$ 41$ million into the Idaho ANP

137 Thumbrail sketch March 1959.

138 Thumbnail sketch 1960.

139 Thumbnail Sketch November 1958 and March 1959.

140 Personal communication with Idaho Department of Employment analyst Janell Hyer, October 24, 1994.

${ }^{141}$ To Senator William F. Knowland from Henry Dworshak, November 24, 1956; Dworshak Papers, Box 59, File: Legis AEC Miscellaneous. 
INEL, TAN, HANGAR 629

HAER NO. ID-32-A

Page 74

buildings and facilities through 1961.142

The presence of the nuclear research industry in Idaho has had a profound influence upon the state's politics at every level. Aside from the interest of its senators in the Congressional appropriations for the site, (an interest that continued with senator Dworshak's successors), governors, state legislators, and local officials all protected, advocated, or contested in various ways the activities at the site.

In the 1970s, when grass roots environmental movements in Idaho began fighting for wilderness designation for various roadless areas in the central Idaho mountains, much of the leadership came from scientists and engineers working at the Site. Environmental issues in the 1980 s shifted to concerns that the storage of nuclear waste at the site might be posing a threat to the water supply of the Snake River Plain Aquifer. Conflicts over these issues have become a significant element of Idaho history in the last fifteen years. 143

Further, retrospective analysis and reconstruction of the release of fissionable materials into the environment by ANP and other projects--and their impacts on human health--have become a very recent subject for research and federal inquiry. In 1994 a large portion of the work being performed at the INEL is research on environmental restoration and waste management. A goal of other research and development work at the site is technology transfer--the commercialization of products and processes heretofore inaccessable to the public.

In summary, the ANP was one of many military research programs that, combined with civilian-oriented nuclear power projects, made the NRTS/INEL site a major economic, political, and social component in the historical development of Idaho in the latter half of the Twentieth century. When national interest in all types of nuclear research began to decline, local interests supporting the INEL as an employer began to search for other missions, a process that continues today.

Nuclear Science

It is fitting to recall that thousands of men and women devoted their career energies to the patriotic mission and scientific challenge of developing an atomic aircraft for their

142 Comptroller General, Schedule "Costs of Facilities and Equipment by Major Location," page 113.

143 See Pat Ford, "Nuclear Northern Rockies," unpublished and undated manuscripts loaned to the author by Pat Ford. 
INEL, TAN, HANGAR 629

HAER NO. ID-32-A

Page 75

country. Distant from the chronic struggles over "redirection" among politicians, generals, advisors, and lobbyists in washington, huge teams of scientists, architect/engineers, construction contractors, mechanics, welders, health physicists, and other specialists doggedly removed one barrier after another in the way of the goal.

After the program was canceled, Nucleonics magazine, which served the nuclear science professions and industry, asked "What Did We Get for our Money?" Air Force General Irving F. Branch, who had replaced Donald Keirn as head of the ANP program. answered this "\$1 Billion Question." The money and the 15-year life of the project had not been enough to produce the ultimate solution to materials, shielding, aircraft speed, or accident hazards of the atomic bomber, but the approach to that target produced a wide range of yseful contributions to nuclear science beyond the ANP program. $144_{\text {Branch cited several examples: }}$

Reactor systems. ANP designed and built the first "swimmingpool" reactor, which served as a model for dozens of other similar reactors all over the world. These were made to learn about large shield components. The Heat Transfer Reactor Experiments, aside from proving the principle of direct-cycle nuclear propulsion, advanced the understanding of various fuel elements, solid moderators, metallic fuel, and ceramic fuels. HTRE-3 was the first reactor to use a solid hydrogenous moderator. At Oak Ridge, the spherical $5 \mathrm{MW}$ reactor that hung from steel towers in the open air continued in studies of radiation effects and radiobiology. Efforts to reduce reactor weights led to reductions from 500-1,000 tons to 100 tons. The use of zirconium hydride solid-moderator technology led to further research in the use of nuclear power for aerospace applications. (See discussions earlier in this paper on the Lithium Cooled Reactor Experiments and the SNAP program.)

Fuels. ANP pioneered the development of uranium oxide and other ceramic fuels. Production techniques for combining beryllium, uranium oxide, and yttrium oxide as homogenous fuel elements demonstrated that this fuel could be used in an air environment. Other work led to better forecasting of the operating life of this and other fuel elements at various high temperatures and at specific power levels. Metallic dispersion fuel elements developed for the direct cycle reactor were later

144rving F. Branch, "What Did We Get for our Money? Gen. Branch Answers the $\$ 1$ Billion Question," Nucleonics (August 1961), p. 26-27. See also Appendix V of the Comptroller General report, p. 182 for another summary of ANP contributions to reactor technology, this one dated January 2, 1962. 
INEL, TAN, HANGAR 629

HAER NO. ID-32-A

Page 76

used for an Army program to develop a portable power reactor, for the Gas Cooled Reactor Experiment (at the Site), and for a commercial nuclear superheat reactor at Sioux Falis. ANP also developed a high-temperature boron braze, which became widely used for stainless steel and nichrome in various reactor applications.

Materials. ANP scientists created a high-strength refractory metal--a niobium-zirconium alloy--for use in high-temperature reactors. They also developed an economic process for producing lithium-7 in large quantities. This metal, one of two isotopes of lithium, can be used as a reactor coolant, whereas Lithium-6, the more common isotope of lithium, cannot. Metals were tested and found to succeed (or fail) in high heat environments for use as coolant pumps, valves, seals, heat exchangers, and instrumentation. These tests advanced the general scientific understanding of corrosion and the process of corrosion on numerous alloys. 145 ANP developed yttrium to give oxidation resistance to stainless steel. This was being produced commercially by 1961. Yttrium-stabilized zirconium crucibles, also in use by industry before 1961, were developed first by ANP metallurgists. The search for radiation-resistant lubricants discovered a polyphenyl ether that retained its properties under radiation at 425 degrees $F$. for over 1,000 hours without breaking down.

Shielding. Up to 1961 the majority of the world's shielding research (excluding what might have occurred in the soviet Union) was sponsored by ANP. Findings were absorbed by civilian power, Navy, maritime, Army package-power, and space reactor programs. Further, ANP pioneered the use of electronic computers in calculating shielding requirements and performance. New shielding materials at lighter weights prompted one shielding specialist to say as early as 1957 that "It seems safe to say...that even with present knowledge, applied with appropriate conservatism, the airplane is pot being kept from flying because of the weight of the shield."146

Components. Electronic components had to withstand radiation; thus ANP workers designed and made them; many were used later in other nuclear experiments and projects. Additionally, ANP engineers improved the performance and miniaturization of various measuring instruments. They developed

145 High temperature pumps, etc, were used in development of Sodium Graphite Reactor, Liquid Metal Fuel Reactor, and the Enrico Fermi Fast Breeder Reactor.

$$
146 \mathrm{APEX}-322 \text {, page } 1-2 \text {. }
$$




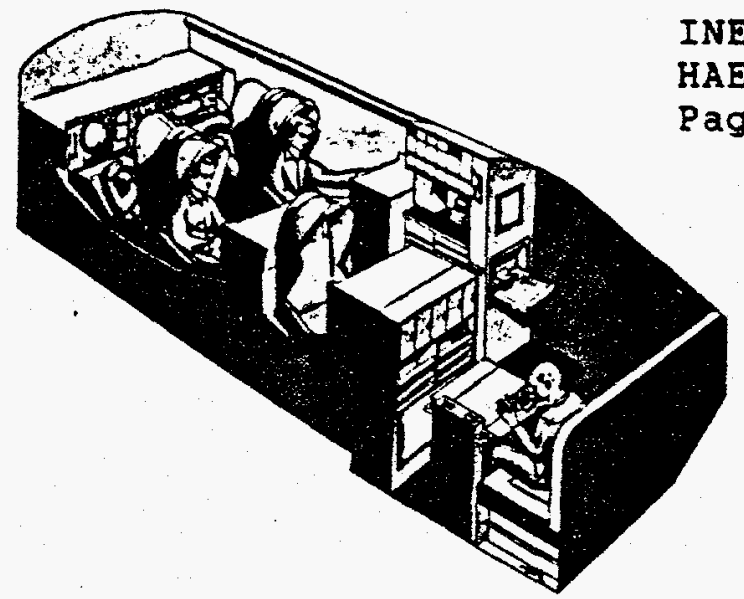

INEL, TAN, HANGAR 629

HAER NO. ID-32-A

Page 77

Figure 14. Artist's sketch of the crew compartment design and arrangement shows the commander of the nuclear aircraft in compartment at the right, immediately aft the integrated feeding system. Other members of the crew were to include a nuclear engineer, a bombardier-navigator, defense director, and a copilot. Source: Gantz, Nuclear Flight, p. 175

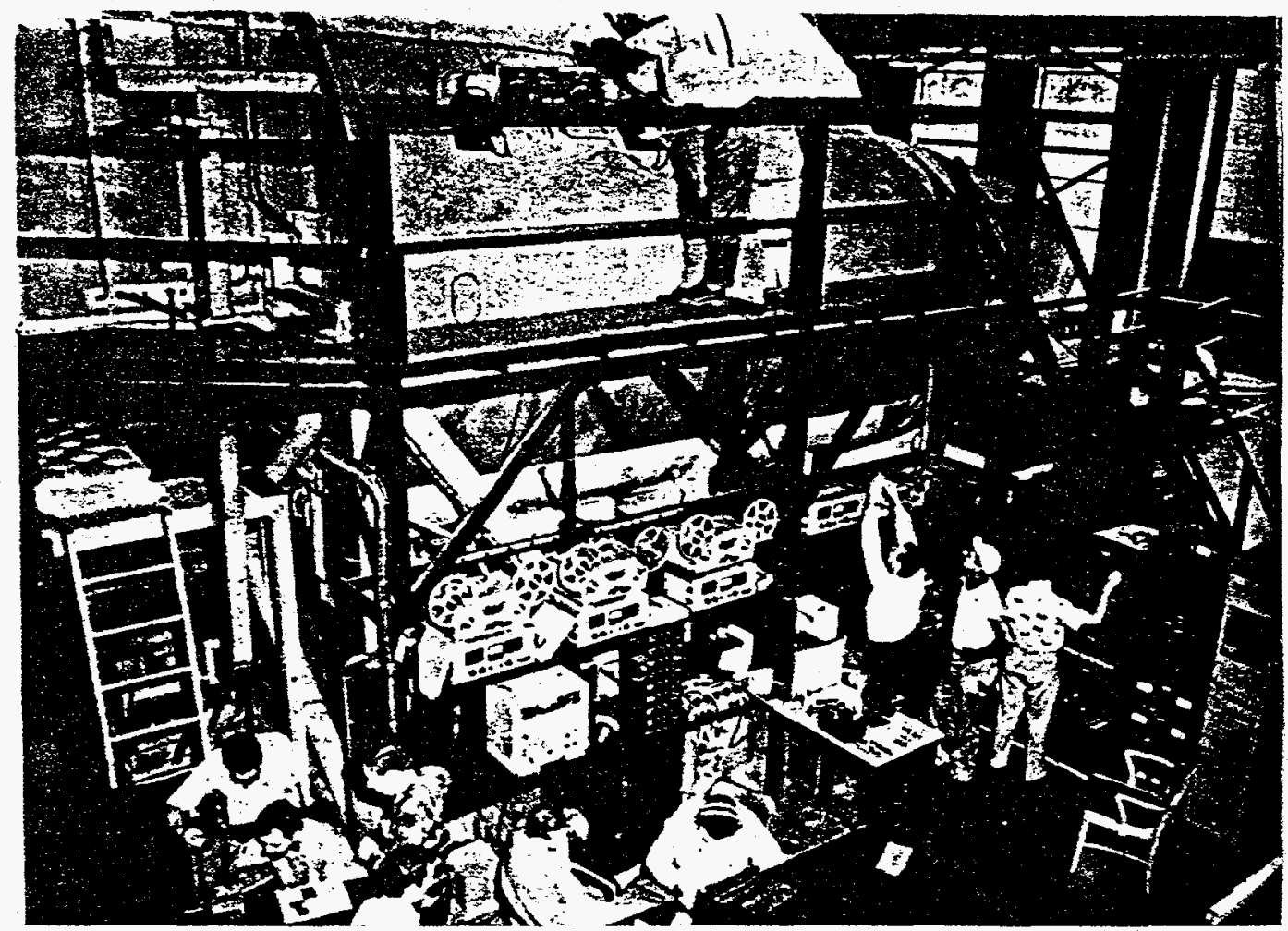

Figure 15. The U.S. Air Force built a Nuclear Aircraft Simulator Facility at Wright Air Development Center in ohio. At right, four metal cabinets house the electronic equipment used in gathering. data on the physiological and psychological state of the crew members during their experimental "flights" in the simulator. At top, a technician adjusts one of the time-lapse cameras that recorded the movenents of the crew during the flights. In the left foreground is the control center, where the data was recorded. Source: Gantz, Nuclear Flight, p. 174. 
INEL, TAN, HANGAR 629

HAER NO. ID-32-A

Page 78

moving-wire fission gas detectors, high-temperature ionization chambers, and fission chambers. The ANP designed and built the first large-scale hot shop for work on entire reactors. The need to filter jet exhaust during HTRE operations led to data on eletrostatic precipitator systems for filtering effluent air later used in civilian and gas-cooled reactor programs.

Reactor Theory. ANP's accumulated experience with reactor controls led to the control system used for a later plutonium Recycle Test Reactor. Data on the rate of heating in various nuclear materials became of wide and general industrial use. ANP developed various innovative techniques for flattening power production, including the invention of a poison wire method. ANP's analytical methods were programmed for computer use and these were shared within the nuclear industry.

Reactor Safety. Meltdown experiments generated information about fission-product dispersal, particle size, ground deposition rates, and airborne release activity. Several fuse devices used to improve reactor safety were used in later reactor programs.

Training. The ANP contractors were responsible for training hundreds of nuclear engineers and scientists who went on to other fields of research or production after the program ended.

A more detailed examination of the scientific legacy of the ANP project from the perspective of 1994 is beyond the scope of this report. High temperature materials and shielding studies undoubtedly contributed to the space program. It is also possible that ANP efforts to design a compact compartment for the occupation of a flight crew contributed to the design of crew compartments for earth-orbiting astronauts.

Hundreds of technical papers, such as General Electric's APEX reports, circulated among scientists who were qualified (by security clearances) to read them at the time. Today, most of these reports have been declassified and constitute a resource to science and industry.

\section{Architecture}

As a purely architectural artifact, the TAN 629 Hangar is unique as America's only structure intended to house an atomic airplane. The barrel-vault ribbed structure itself is not unique; buildings of similar style stand all over the country. However, this is the only one with a shielded coupling station, shielded viewing windows, a shadow shield, shielded exit tunnels below ground level, and to which a dolly on a four-rail track was envisioned towing a nuclear test aircraft. 
INEL, TAN, HANGAR 629

HAER NO. ID-32-A

Page 79

\begin{tabular}{|c|c|c|c|}
\hline \multicolumn{4}{|c|}{$\begin{array}{c}\text { Recommended Menu for } \\
\text { 120-Hour Flight }\end{array}$} \\
\hline & breakfast & lunch. & dinner \\
\hline $\begin{array}{l}\text { Ist } \\
\text { day }\end{array}$ & eoten of home & $\begin{array}{l}\text { apple juice } \\
\text { pork steak } \\
\text { bread and butter } \\
\text { jom } \\
\text { pineapple } \\
\text { poundcake } \\
\text { coffee, tea, cocoa }\end{array}$ & $\begin{array}{l}\text { chicken soup } \\
\text { beef pot roost } \\
\text { potatoes } \\
\text { mixed vegetables } \\
\text { bread and butter } \\
\text { jelly } \\
\text { brownies } \\
\text { milk, colfee, teo, } \\
\text { cocoo }\end{array}$ \\
\hline $\begin{array}{l}\text { 2nd } \\
\text { day }\end{array}$ & $\begin{array}{l}\text { orange juice } \\
\text { grilled egg and bacon } \\
\text { sandwich } \\
\text { milk, coffee, tea, } \\
\text { cocoa }\end{array}$ & $\begin{array}{l}\text { tomato soup } \\
\text { Swiss steak } \\
\text { potatoes and peas } \\
\text { bread and butter } \\
\text { apple and cheese slice } \\
\text { coffee, tea, cocoa }\end{array}$ & $\begin{array}{l}\text { pineopple juice } \\
\text { meat and spoghetti } \\
\text { bread and butter } \\
\text { jelly } \\
\text { apricols } \\
\text { fruit cake } \\
\text { caffee, tea, cocoo }\end{array}$ \\
\hline $\begin{array}{l}\text { 3rd } \\
\text { day }\end{array}$ & $\begin{array}{l}\text { tomato juice } \\
\text { waffles } \\
\text { applesauce } \\
\text { sausage } \\
\text { honey } \\
\text { coffee, tea, milk }\end{array}$ & $\begin{array}{l}\text { chicken soup } \\
\text { grilled ham and } \\
\text { cheese sandwich } \\
\text { cookies } \\
\text { nuts and candy } \\
\text { milk, coffee, tea, } \\
\text { cocoo }\end{array}$ & $\begin{array}{l}\text { opple juice } \\
\text { turkey } \\
\text { sweet pototoes and } \\
\text { Limo beons } \\
\text { breod and butter } \\
\text { cranberry souce } \\
\text { fruit cocktail } \\
\text { cookies } \\
\text { coffee, teo, cocoo }\end{array}$ \\
\hline $\begin{array}{l}4 t h \\
\text { day }\end{array}$ & $\begin{array}{l}\text { apricot juice } \\
\text { grilled egg and bacon } \\
\text { sand wich } \\
\text { milk, coffee, teo, } \\
\text { cocod }\end{array}$ & $\begin{array}{l}\text { orange juice } \\
\text { chicken } \\
\text { bread and butter } \\
\text { cranberry sauce } \\
\text { pears } \\
\text { pecon roll } \\
\text { coffee, tea, cocoo }\end{array}$ & $\begin{array}{l}\text { tomoto soup } \\
\text { beefsteok } \\
\text { bread and butter } \\
\text { ketchup } \\
\text { apple } \\
\text { date pudding } \\
\text { coffee, teo, cocoo }\end{array}$ \\
\hline $\begin{array}{l}5 t h \\
d a y\end{array}$ & $\begin{array}{l}\text { pineapple iuice } \\
\text { Spanish omelet } \\
\text { sausage } \\
\text { sweet roll } \\
\text { coffee, ted, cocoa }\end{array}$ & $\begin{array}{l}\text { apricot nector } \\
\text { chicken w/grovy } \\
\text { potatoes and corn } \\
\text { bread and butter } \\
\text { honey } \\
\text { brownies } \\
\text { milk, coffee, tea, } \\
\text { cocoa }\end{array}$ & $\begin{array}{l}\text { tomato juice } \\
\text { beef patty } \\
\text { potatoes and green } \\
\text { beans } \\
\text { bread and butter } \\
\text { peach pie } \\
\text { caramels } \\
\text { coffee, tea, cocoa }\end{array}$ \\
\hline
\end{tabular}

Figure 16. Menu developed at the Nuclear Aircraft Simulator Facility. Source: Gantz, Nuclear Flight, p. 178. 
INEL, TAN, HANGAR 629

HAER NO. ID-32-A

Page 80

As is obvious from this review of ANP's place in several historical contexts, the TAN 629 hangar plays a rather modest role. Primarily it is a reminder of the ANP program that conceived and built it, and that, like the hangar, was abandoned without realizing the vision that had given it birth. 
INEL, TAN, HANGAR 629

HAER NO. ID-32-A

APPENDIX A

Page 81
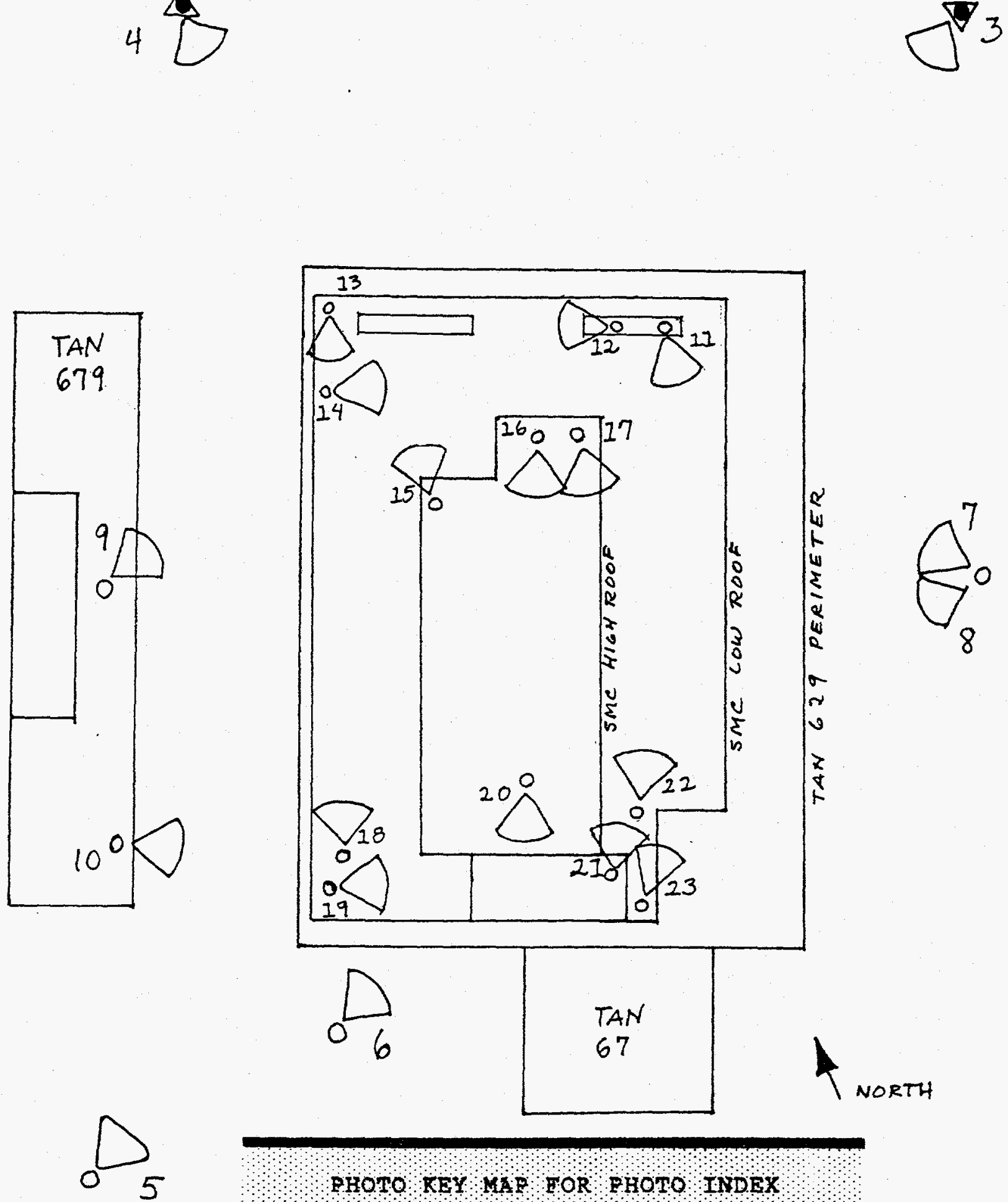

PHOTO KEY MAP HOR FHOTO TNDEX

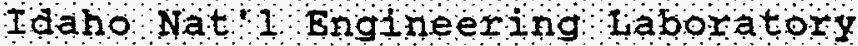

TEST AREA NORTH HANGAR 629

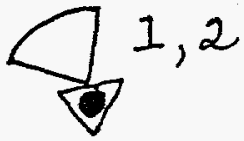

Photograph Numbers

ID $-32-A-1$ through I $-32-A-23$

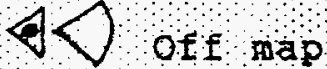

(Not to scale) 


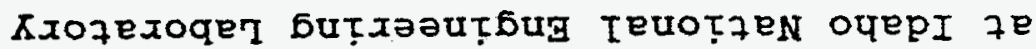

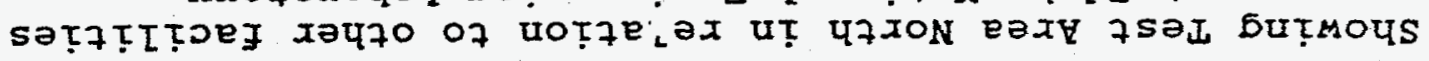

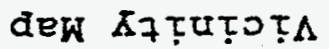

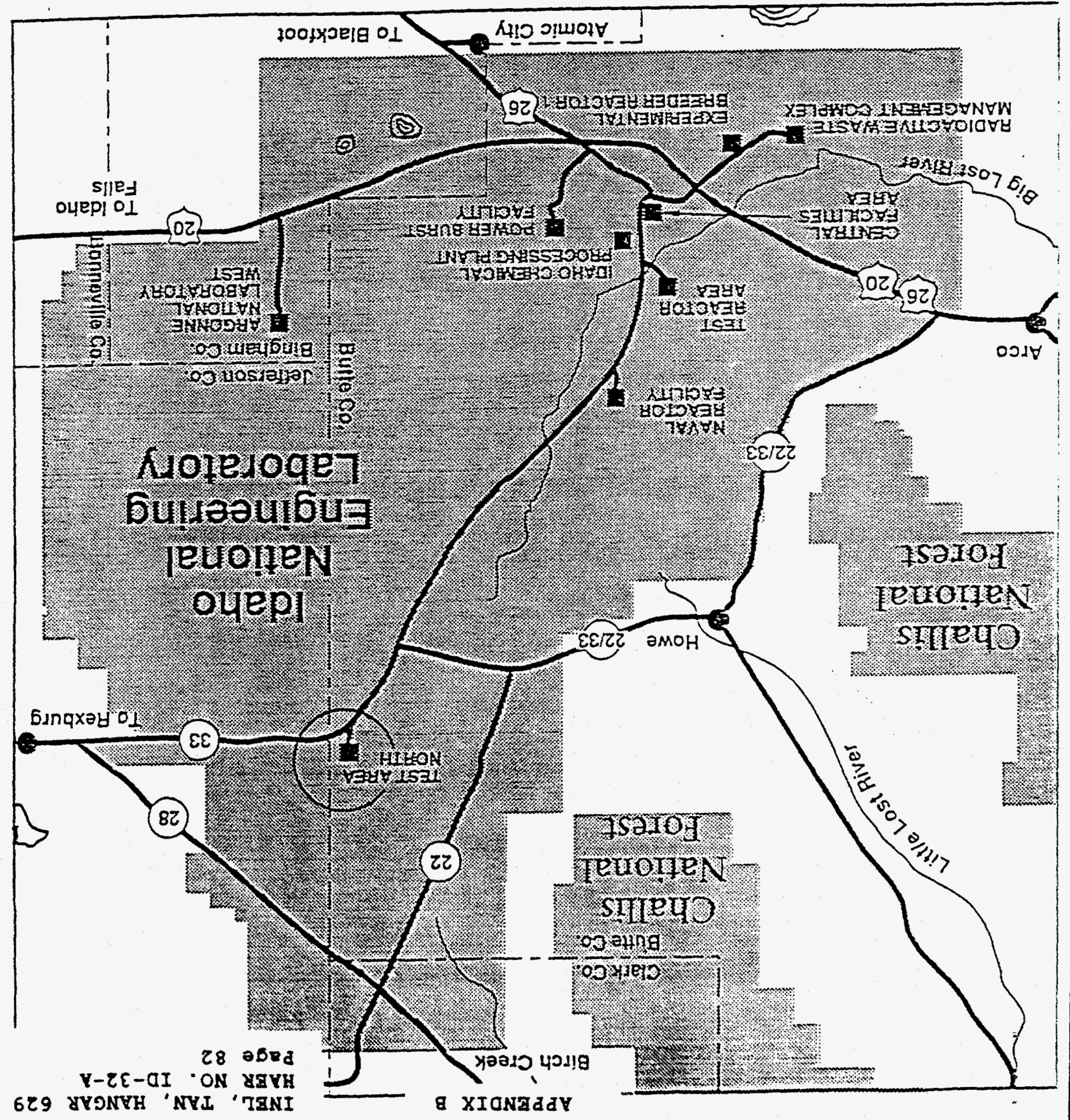




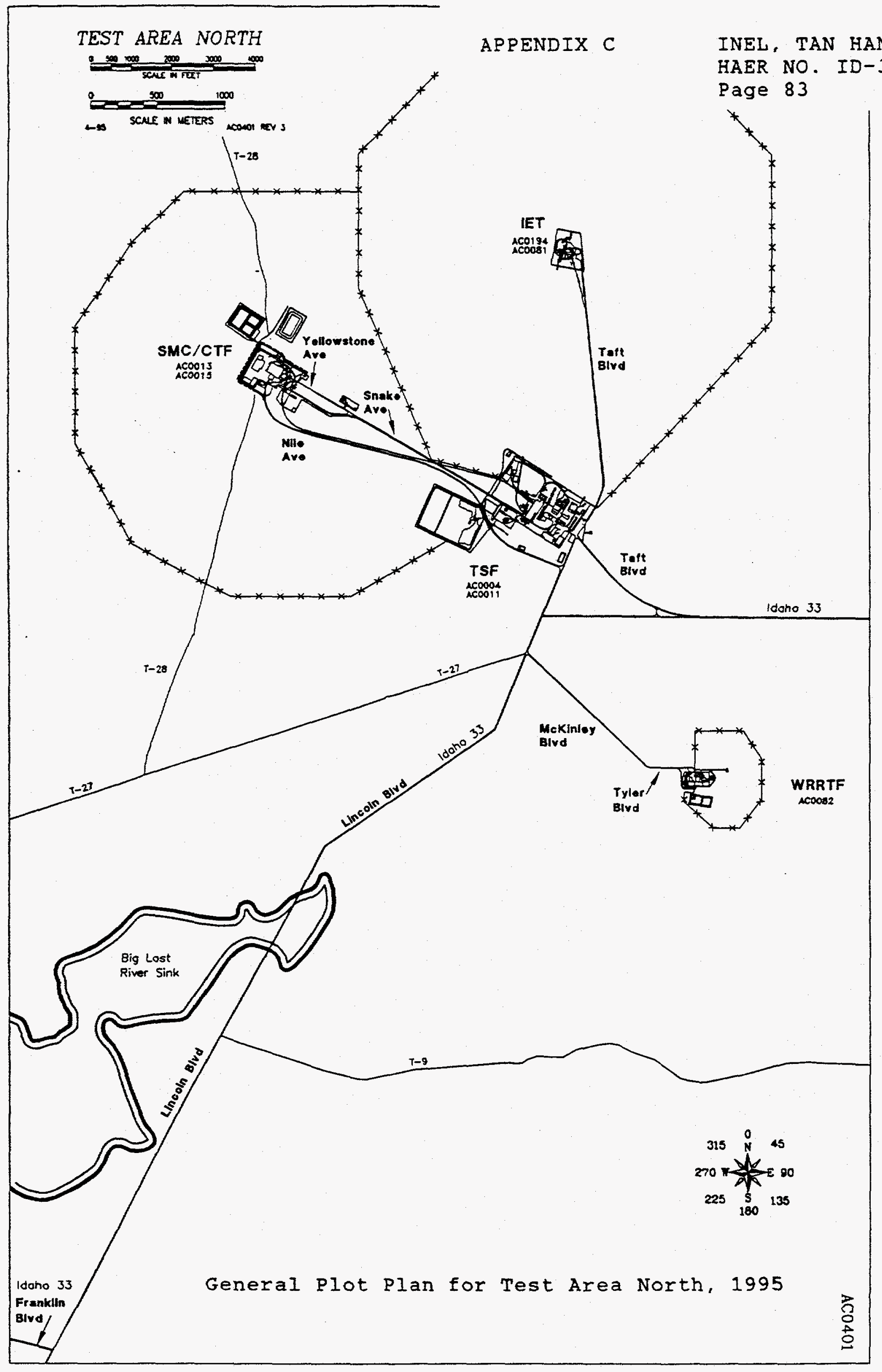




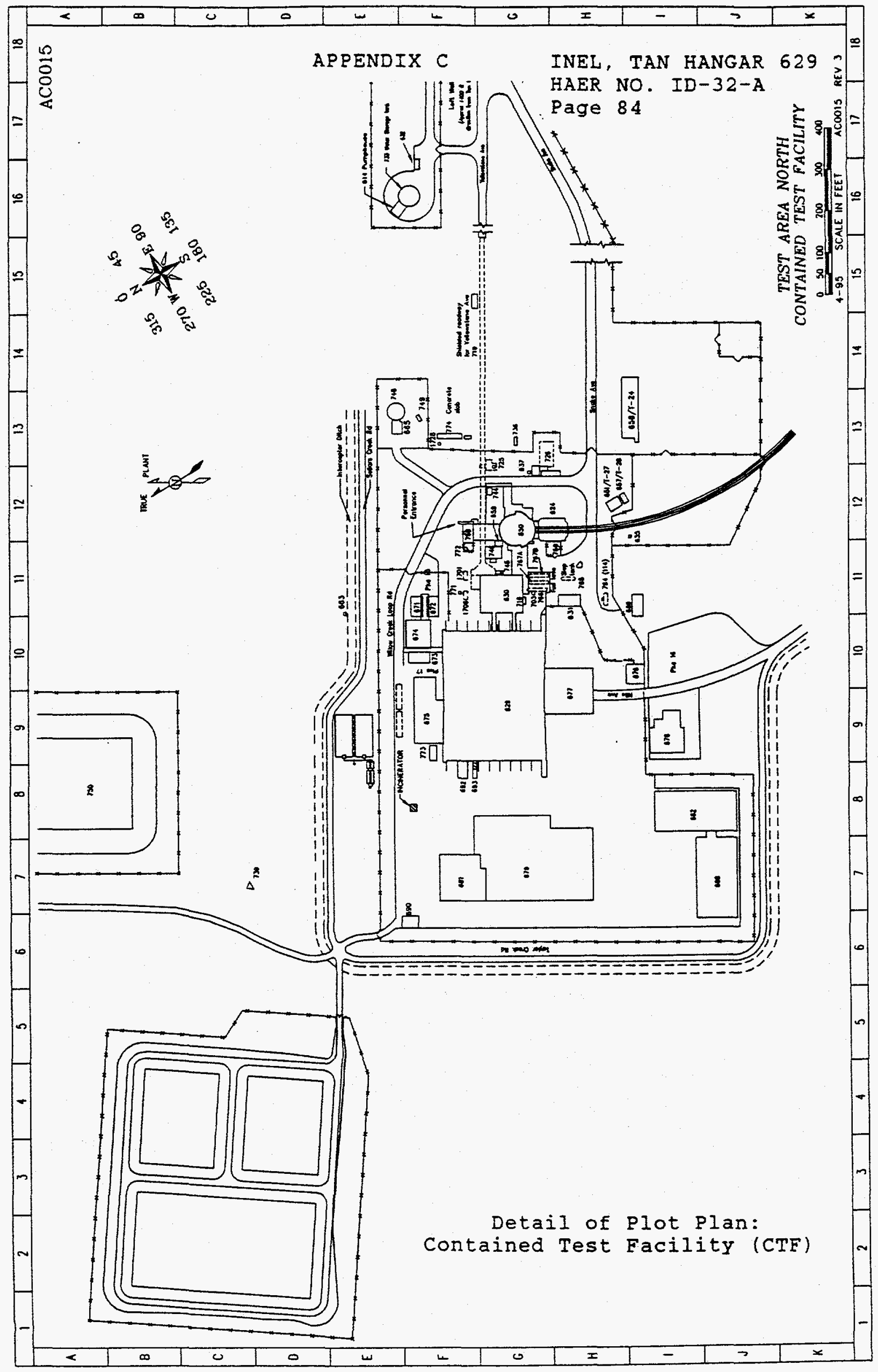




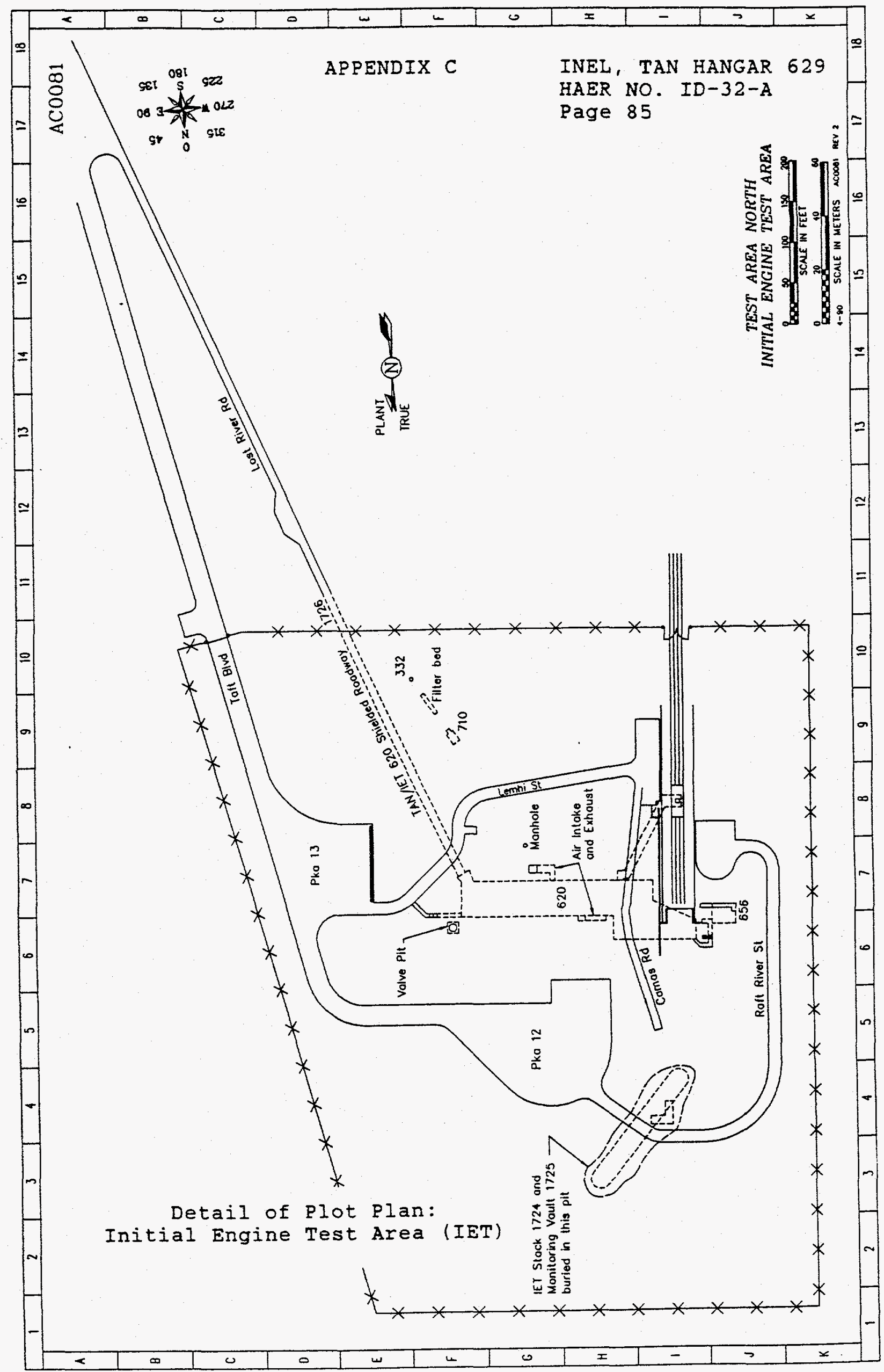




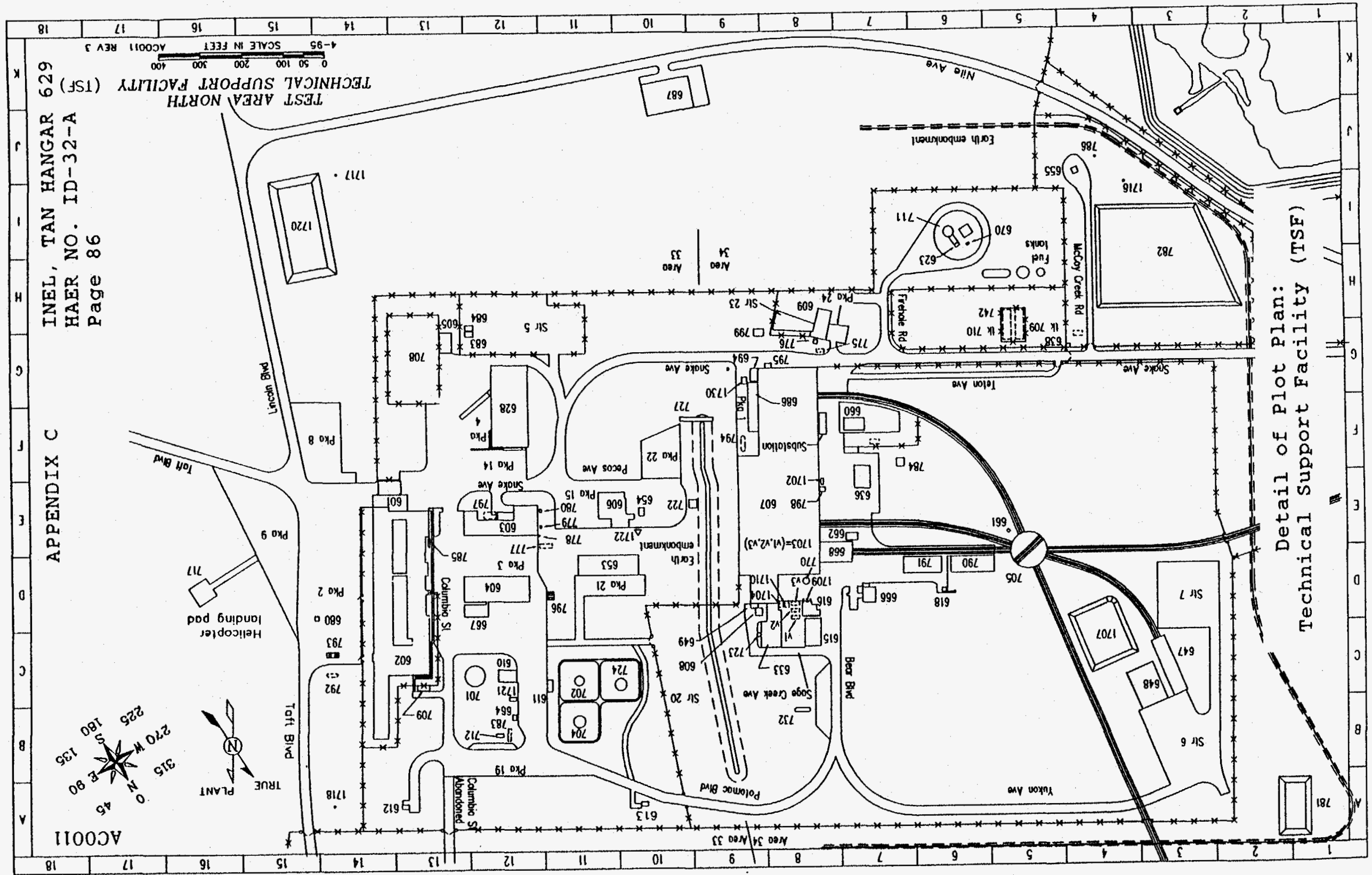




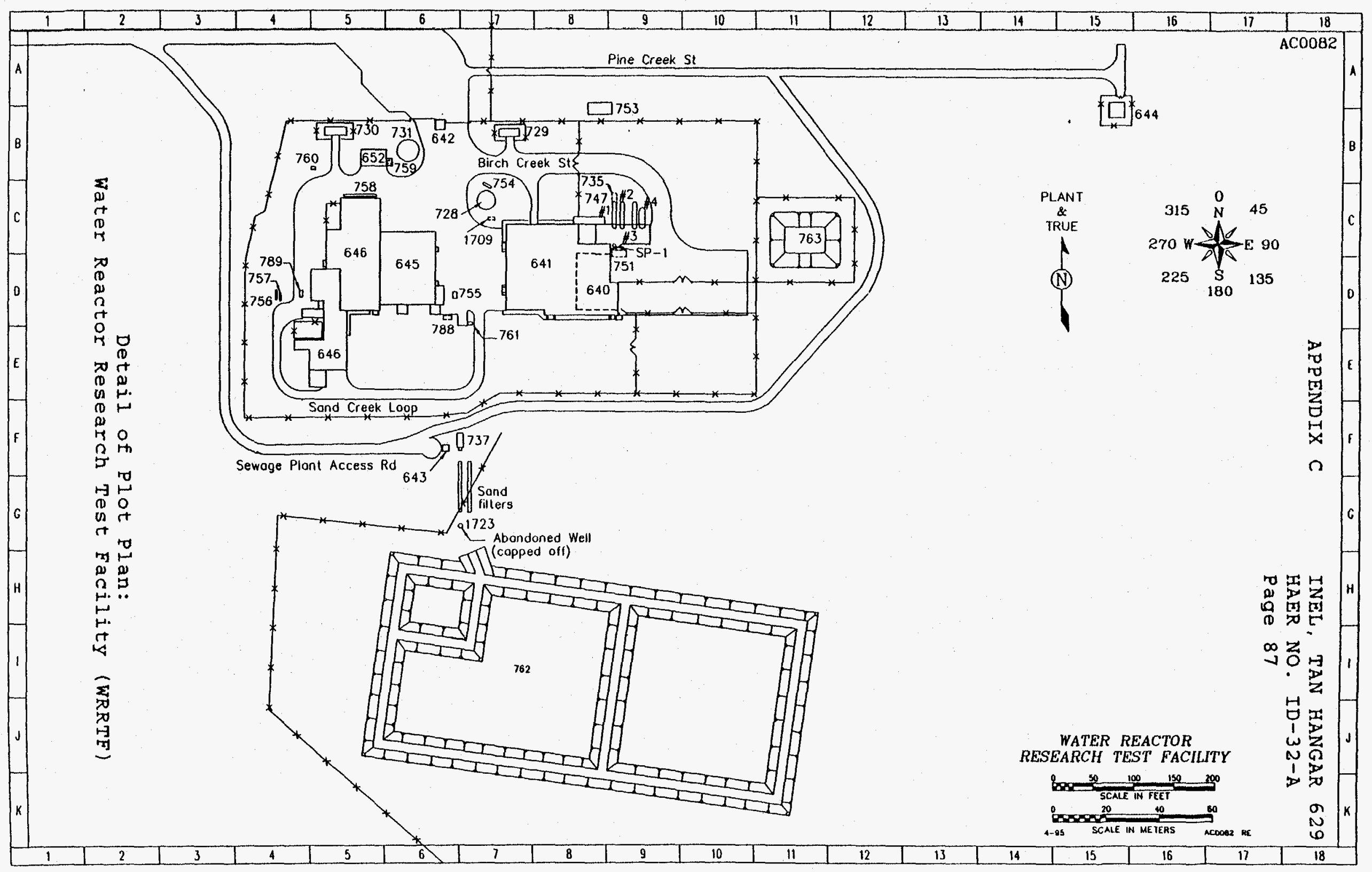


INEL, TAN, HANGAR 629

HAER NO. ID-32-A

Page 88

BIBLIOGRAPHY

Books, Journals, and Reports

A Historical Brief of the LOFT Project at the Idaho National Engineering Laboratory. Idaho Falls: Aerojet Nuclear Company, 1975.

"ANP Termination Leaves Vast Facilities, Big Technical Legacy." Nucleonics (August 1961), p. 26-27.

Blumberg, stanley $A .$, and Gwinn Owens. The Life and Times of Edward Teller. New York: G.P. Putnam's Sons, 1976.

Branch, Irving F. "What Did We Get for our Money? Gen. Branch Answers the $\$ 1$ Billion Question." Nucleonics (August 1961), p. 26-27.

Braun, Julie. Draft Preliminary Report, Aircraft Nuclear Propulsion Program: TAN Hangar 629. Idaho Falls: INEL, Idaho Field Office, 1993.

Bussard, R.W., and R.D. Delauer. Fundamentals of Nuclear Flight. New York: McGaw Hill, 1965.

Bylinski, Gene. "Monumental Relics of Abandoned Technology." Fortune (January 28, 1980), p. 90-95.

Carver, Martha, and Margaret Slater.Architectural/Historical Assessment of the Oak Ridge National Laboratory, Oak Ridge Reservation, Anderson and Roane Counties, Tennessee. Oak Ridge: Martin Marietta, 1994. ORNL/M-3244.

Design Criteria for Lithium-CRE at NRTS. CNLM-4043. Middleton, Connecticut: Pratt and Whitney Aircraft, Division of United Aircraft Corporation, CANEL, 1962.

Eisenhower, Dwight David. Mandate for Change, 1953-1956. Garden City, N.Y.: Doubleday and Co., 1963,

Eisenhower, Dwight David. Waging Peace, 1956-1961. Garden City, N.Y.: Doubleday and Co., 1965.

Fast, E. compiler. Potentially Available Facilities at the National Reactor Testing Station. Idaho Falls: Eastern Idaho Nuclear Industrial Council, 1970. 
INEL, TAN, HANGAR 629

HAER NO. ID-32-A

Page 89

Feynman, Richard. What Do YoU Care what other People Think?

Boston: G.R. Hall and Co., 1990.

Gantz, Kenneth F., ed. Nuclear Flight. New York: Due11, Sloan, and Pearce, 1960.

Hacket, Bill, Jack Pelton, and Chuck Brockway. Geohydrologic Story of the Eastern Snake River Plain and the Idaho

National Engineering Laboratory. Idaho Falls: U.S. Dept. of Energy Idaho Operations Office. Idaho National Engineering Laboratory, 1968.

Haines, Frank D. "SNAP-50/SPUR Reactor Development." Unpublished paper. INEL Technical Library, Idaho Falls, no date.

Harmon, L.F. General Electric Aircraft Nuclear Propulsion Systems Applications For The National Defense. Cincinnati: GE Atomic Products Division, ANPD, MaY 9. 1958.

Heiman, Grover. Jet Pioneers. New York: Duell, Sloan, and Pearce, 1963.

Hewlett, Richard G., and Francis Duncan. Atomic Shield, 1947 -1952. Volume II of a History of the United States Atomic Energy Commission. Pennsylvania state University Press, 1969 .

Hogerton, John F. The Atomic Energy Deskbook. New York: Reinhold Publishing Corporation, 1963.

Holl, Jack M., Roger M. Anders, and Alice Buck. United States Nuclear Power Policy, 1954-1984: A Summary History. Washington, D.C.: U.S. Department of EnergY, Office of Executive Secretariat, History Division, DOE/MA-0152, 1986.

Horton, J.R., et al. Occupational Radiation Exposure History of Idaho Field office operations at the INEL. Idaho Falls: BGGCS-11143, October 1993 .

Jane's All The Forld's Aircraft, 1954-55. New York: Franklin Ratts, 1955.

Kogan, Philip. The Cosmic Power, Foundations of Nuclear Physics. London: Sampson Low, Marston and Co., 1966.

Lambright, W. Henry. Shooting Down the Nuclear Airplane. Syracuse, NY: Inter-University Case Program, No. 104, 1967.

Maclean, Norman. Young Men and Fire. Chicago: University of Chicago Press, 1992. [See p. 254-55.] 
INEL, TAN, HANGAR 629

HAER NO. ID-32-A

Page 90

Pach, Chester J., Jr., and Elmo Richardson. The Presidency of Dwight David Eisenhower. Lawrence: University Press of Kansas, 1991.

Oppenheimer, J. Robert. The Flying Trapeze: Three Crises for Physicists. London: Oxford University Press, 1964.

Parmet, Herbert S. Eisenhower and the American Crusades. New York: Macmilian Company, 1972.

"Pratt and Whitney gets Major Nuclear-Space Assignment: SNAP-50 Reactor Systems." Nucleonics Week (Volume 3, Number 13, March 29, 1962), p. 1

Rabi, I.I, Robert Serber, Victor Weisskipf, Abraham Pais, Glenn T. Seaborg. Oppenheimer. New York: Charles Scribner's Sons, 1969.

Reactor Operations Final Report, LCRE. PWAC-408. Middleton, Connecticut: AEC Research and Development Department, Pratt and Whitney Aircraft, 1964.

Schlesinger, Arthur M., Jr. A Thousand Days, John F. Kennedy in the White House. Boston: Houghton Mifflin Co., 1965.

Segre, Emilio. Enrico Fermi, Physicist. Chicago: University of Chicago Press, 1970.

Snow, C.P. The Physicists. Boston: Little, Brown, and Co., 1981.

"Soviets Flight Testing Nuclear Bomber." Aviation Week (December 1, 1958), p. 28 .

Tierney, John. "Take the A-Plane: The $\$ 1$ Billion Nuclear Bird that Never Flew," Science 82 Vol 3, No 1 (Jan/Feb 1982), p. 46-57.

Truman, Harry S. Memoirs, Years of Trial and Hope. Garden City, N.Y.: Doubleday and Co., 1956.

United states. Comptroller General of the United States. Review of Manned Aircraft Nuclear Propulsion Program, Atomic Energy Commission and Department of Defense, Report to the Congress of the United States. Washington, DC: General Accounting Office, February 1963.

United states. Atomic Energy Commission. Idaho Operations Office. Thumbnail sketch. Idaho Falls: Idaho Operations office, National Reactor Testing Station, Issues published variously between 1956-1973. 
INEL, TAN, HANGAR 629

HAER NO. ID-32-A

Page 91

- Department of Energy. The US Civilian Nuclear Power

Policy, 1954-1984: A Summary History. Washington: office of Executivy Secretariat History Division, February 1986. [DOE/MA-0152.]

Whitman, willson. David Lilienthal, Public servant in a Power Age. New York: Henry Holt and Co., 1948.

York, Herbert. Race to Oblivion. New York: Simon and Schuster, 1970 .

\section{APEX Series Reports}

Unless otherwise indicated, all APEX reports were published by General Electric Aircraft Nuclear Propulsion Department, Atomic Products Division, Cincinatti, Ohio.

APEX-13, ANPP Engineering Program Progress Report No. 13, September 1954 .

APEX 14, ANPP Engineering Program Progress Report No. 14, December 1954 .

APEX-15, ANPP Engineering Program Progress Report No. 15, March 1955 .

APEX-18, ANPP Engineering Program Progress Report No. 18, December 1955.

APEX-36, ANPP Engineering Program Progress Report No. 36, June 1960 .

APEX-37, ANPP Engineering Program Progress Report No. 37 , september 1960 .

APEX-131, Nuclear Power Plant Testing in the IET, May 1953.

APEX-217, Design Criteria: Shield Test Facility. Idaho Falls: General Electric Aircraft Nuclear Propulsion Department, Idaho Test Station, April 23, 1956.

APEX-225, D.J. Blevins, et al. Flight Engine Test Facility Design Criteria. Idaho: GE ANP Department Idaho Test Station, December $16,1955$.

APEX-322, Semiannual ANP Shielding Information Meeting, May 1-2, 1957, Vol 1. 
INEL, TAN, HANGAR 629

HAER NO. ID-32-A

Page 92

APEX-445, Final Report, First Meltdown Experiment loperation BOOT), January 2, 1959 .

APEX-901, Thornton, G., A.J. Rothstein, and D.H. Culver, ed. Comprehensive Technical Report, General Blectric Direct-AirCycle Aircraft Nuclear Propulsion Program, Program Summary and References, June 28, 1962.

Manuscript and Archival Collections

Church, Frank. Papers. Boise State University Library, Boise, Idaho.

Dworshak, Henry. Papers. Idaho Historical Society, Boise, Idaho.

Document Storage Warehouse. Central Facilities Area, Idaho National Engineering Laboratory, Department of Energy.

Newspapers

Boise Idaho statesman

Cincinatti Aircraft Nuclear Propulsion Department News

Idaho Falls post Register

Idaho Falls GE News (Idaho Test Station, Aircraft Nuclear Propulsion Department)

Pocatello Idaho State Journal

Interviews

Col. Frank Heasley, USAF Harold Rauh

Janell Hyer Bud White

John James Eric Yde

Rod Kemper 